\title{
A High-Resolution Hydrodynamic Investigation of Brown Trout (Salmo trutta) and Rainbow Trout (Oncorhynchus mykiss) Redds
}

\author{
by \\ Mason A. Marchildon
}

\begin{abstract}
A thesis
presented to the University of Waterloo in fulfillment of the thesis requirement for the degree of Master of Applied Science
\end{abstract}

in

Civil Engineering

Waterloo, Ontario, Canada, 2009

(c) Mason A. Marchildon 2009 
I hereby declare that I am the sole author of this thesis. This is a true copy of the thesis, including any required final revisions, as accepted by my examiners.

I understand that my thesis may be made electronically available to the public. 


\begin{abstract}
High-resolution velocity measurements were undertaken over a series of redds and riffles on a gravel-bed stream to quantify the hydrodynamics preferred by spawning brown trout (Salmo trutta) and rainbow trout (Oncorhynchus mykiss) for redd-site selection. On each riffle studied, over 6,000 velocity measurements per day were acquired to quantify the velocity, depth, Reynolds number, Froude number, bed shear, and turbulent kinetic energy per unit area of streambed in attempts to relate fluid properties to redd-site selection, relative to remaining riffle structures. Results showed that velocity, Reynolds number, and Froude number vary widely at the redd- and riffle-scale with no apparent correlation to spawning location preference. Turbulent kinetic energy per unit area consistently demonstrated a strong correlation with redd locations whereby the metric maintained low values (i.e., unidirectional flow with little turbulence) where redds and attempted redds were observed. Habitat suitability indices were applied at the reach-, riffle-, and redd-scale using the results of the high-resolution velocity measurements. Findings demonstrated that habitat suitability indices, which are based on reach-scale hydraulics, were adequately represented at the reach scale. However, by decreasing the scale to the riffle- or redd-scale, where increasing heterogeneity in the flow regime is revealed, habitat suitability indices failed to adequately reflect the habitat conditions preferred by the spawning fish.
\end{abstract}




\section{Acknowledgements}

I would very much like to thank my supervisor Dr. William K. Annable for his unrelenting support and inspiration. Without Bill, I would have never learned the many lessons that, although difficult at the time, I now hold dearly. It definitely takes a character like Bill's to help fine tune a concise scientific document from my imaginative and creative (and many times long-winded) writing style.

This work, which involved many days of field work, could not have been accomplished without the help of the following: Rob Amos, Pete Thompson, Michael Fabro, Terry Ridgway, Laddie Kuta, Emanuela Ferrari, Richard Benko, and Keith Moggach. After the many hours spent with my laptop developing the data processing programs, I could never forget the support of Michael Faulkner and Barry Brouwers.

I would like to extend my thanks to Jack Imhof, whose lecture inspired me to choose this thesis topic, and for the countless meetings and site visits. Furthermore, I would like to thank both Andrea Dunn and Rachel Martens of Conservation Halton and Jack Griffin and Patty Asquith of the Grand River Conservation Authority for their aid with my preliminary site visits. I would like to thank Lynn Bouvier

and Mary Finch of the American Fisheries Society-Ontario Chapter, where I was invited to present my preliminary findings at their annual general meeting. I was later awarded best student presentation, a merit for which I must thank Margaret Crossman.

To the department of Civil and Environmental Engineering, the NSERC Discoveries Grant Program, and Trout Unlimited Canada: Thank you for the support.

Finally, I would like to thank Allie Service for her moral support. It's been a long time coming. 


\section{Contents}

List of Tables vii

List of Figures viii

Symbols and Nomenclature xii

1 Introduction 1

2 Background $\quad 4$

2.1 Spawning and redd construction of salmon and trout . . . . . . . 4

2.2 The selection of suitable redd sites . . . . . . . . . . . . . 8

2.2.1 Redds in high-flow conditions . . . . . . . . . . . . . 12

2.2.2 Habitat Suitability Curves . . . . . . . . . . . . . . . 13

2.3 River morphology . . . . . . . . . . . . . . . . 15

2.3.1 Channel roughness . . . . . . . . . . . . . . . 18

2.3.2 Sediment transport . . . . . . . . . . . . . . . 19

2.3.3 Boundary-layer flow . . . . . . . . . . . . . . . 22

3 Methodology 24

3.1 Site survey . . . . . . . . . . . . . . . . . . . . . . 24

3.2 Sediment sampling . . . . . . . . . . . . . . . . . . . . 28

3.2.1 Critical particle size ............... 30

3.3 Acoustic Doppler Profiler . . . . . . . . . . . . . . . . . 30

3.4 The PCADP Cage . . . . . . . . . . . . . . . . 32

3.5 Post processing and analysis . . . . . . . . . . . . . . 34

3.5.1 Boundary-layer profiles and local shear . . . . . . . . . 34

3.5.2 Local roughness . . . . . . . . . . . . . . . . 37

3.5.3 Turbulent kinetic energy . . . . . . . . . . . . . . 37 
4 Results $\quad 39$

4.1 Sediment analysis . . . . . . . . . . . . . . . . . . . . . . . 39

4.2 Riffle-scale hydrodynamics . . . . . . . . . . . . . . . . . 42

4.3 On the physical habitat of spawning brown and rainbow trout . . . 45 4.3.1 Local-scale spawning assessment . . . . . . . . . . . 45

4.4 One-dimensional hydraulic reach-scale analysis . . . . . . . . . . . . 54

4.5 Riffle-scale spawning assessment . . . . . . . . . . . . . . 61

$\begin{array}{lll}5 & \text { Conclusions } & 76\end{array}$

$\begin{array}{ll}\text { References } & 78\end{array}$ 


\section{List of Tables}

2.1 A collection from various sources of velocity and depth data recorded proximal to redds. Standard error in parentheses. $N D-$ no data. . .

2.2 Discharge-specific physical differences between riffles and pools along a typical riffle-pool channel (modified from Hartley, 1999). . . . . . 17

3.1 Chronology of Whiteman's creek field work. . . . . . . . . . 26

3.2 Success of acquired profiles from each study riffle at varying minimum acceptable coefficients of determination when fit to Equation 3.6. BR1 signifies Brown trout, Riffle 1. . . . . . . . . . . . 36

4.1 Aggregate sediment analysis of three riffle sites at Whiteman's creek. B-2006 brown trout survey; $\mathbf{R}-2007$ rainbow trout survey. All units are $\mathrm{mm} . \ldots \ldots \ldots \ldots \ldots \ldots \ldots \ldots$

4.2 Bray coefficients calculated by Equation 4.1 using six pavement samples and 143 velocity profiles measured within a $1 \mathrm{~m}$ buffer surrounding two rainbow trout redds, based on Equation 4.1. Standard deviations are given between parentheses. . . . . . . . . . . .

4.3 Mean measured data collected from the four study riffles. Flow is estimated from stage-discharge rating curves. $\dagger$-Bed shear calculated using Equation 2.41 and $\ddagger$-Equation 2.25. Standard deviations are given between parentheses. . . . . . . . . . . . . . .

4.4 Summary of critical shear velocity $(\mathrm{m} / \mathrm{s})$, critical velocity $(\mathrm{m} / \mathrm{s})$ and critical shear $\left(\mathrm{N} / \mathrm{m}^{2}\right) \ldots \ldots \ldots \ldots \ldots \ldots \ldots$

4.5 List of sources as labelled in Figure 4.3. . . . . . . . . . . 47

4.6 Bed shear $\left(\mathrm{N} / \mathrm{m}^{2}\right)$ and critical particle size $(\mathrm{mm})$ simulated using HEC-RAS ${ }^{\circledR}$ at $Q_{b f}, Q_{100}$, and at the maximum discharge at Whiteman's creek throughout the time of sampling $\left(Q_{\max }=46.1 \mathrm{~m}^{3} / \mathrm{s}\right)$. 


\section{List of Figures}

2.1 Spawning sequence of river-spawning salmon and trout. The dashed line indicates the limit of undisturbed streambed. a) Pre-spawning stage; b) cutting; c) displacement of streambed material; d) transport of fine-grained sediment downstream; e) oviposition; f) covering of fertilized ova and subsequent upstream pit excavation. Modified from Burner [1951]. . . . . . . . . . . . . . . . . 5

2.2 Typical layout of the redd form, constructed by both salmon and trout, in a) plan view and b) longitudinal profile view. . . . . . . .

2.3 Reynolds and Froude numbers proximal to brown trout and rainbow trout redds reported from fifteen studies. . . . . . . . . . . . .

2.4 Suitability factors for spawning brown trout and rainbow trout, modified form Raleigh et al. [1984,1986]. a) velocity, b) depth, c) substrate size, and d) water temperature. . . . . . . . . . 16

2.5 Force diagram under steady uniform flow (modified from Julien, 1998). 21

3.1 Site location of Whiteman's Creek, Southern Ontario, Canada. . . . 25

3.2 Site map of Whiteman's Creek. R1,R2,R3-Study riffles 1,2,3 respectively. WSC gauge station: Whiteman's creek near Mount. Vernon $(02 \mathrm{~GB} 008) \ldots \ldots \ldots \ldots$

3.3 Discharge record of Whiteman's Creek. Fieldwork chronology as described in Table 3.1. . . . . . . . . . . . . . . . . . 26

3.4 Total station field survey and complementary topographic crosssections of the Whiteman's creek study reach. . . . . . . . . . . . . 27

3.5 Longitudinal profile of Whiteman's creek. R1,R2,R3-High-resolution velocity measurement study riffles $1,2,3$ respectively. . . . . . . . . . 27

3.6 Planimetric sediment sampling locations proximal to redds and at the tops of riffles. . . . . . . . . . . . . .

3.7 PCADP velocity measurements application for sampling depth and resulting velocity profile. CS-cell size; BD-Úblanking distance. . . . 31

3.8 a) Oblique and b) plan-view of the cage. . . . . . . . . . . . . 32 
3.9 Plan view of a riffle reach where multiple cage readings have been undertaken. The shaded area represents a field identified redd. . . .

3.10 The wake caused by outriggers will not interfere with the measurement area. . . . . . . . . . . . . . . . . . . 33

3.11 Frequency distribution of PCADP profile lengths per study riffle. .

3.12 a) Empirically-measured mean profile velocity, $U_{1}$, agrees with $U_{2^{-}}$ mean profile velocity as a function of profile height, intercept, and slope (Equation 3.6). $r^{2}>0.999$. b) Shear velocity as a function of velocity profile slopes, where $u_{* 1}=\kappa b$, agrees with $u_{* 2}$ calculated from Equation 3.10 with known mean profile velocity, depth, and roughness length. $r^{2}=0.998 . n=1853$. Units: $\mathrm{cm} / \mathrm{s} . \ldots \ldots \ldots$

4.1 Aerial photograph of study site outlining locations of the detailed PCADP hydrodynamic analysis. R1 refers to Riffle $\mathbf{1}$. . . . . . . .

4.2 PCADP sample distribution at riffle 2 during the brown trout spawning season (fall 2006). In a patch-work fashion, 20 cage were placed along the study riffle, totalling 943 vertical velocity profiles, each consisting of 39 sample cells, for a grand total of 36,777 point velocity measurements. . . . . . . . . . . . . . . . . .

4.3 Hydraulic data collected proximal to redds from various works listed in Table 4.5. a) Average velocity, b) depth, c) Reynolds Number, and d) Froude Number. Bars indicate \pm standard deviation. . . . .

4.4 Averages of a) mean profile velocity, b) water depth, c) Reynolds number, and d) Froude number stratified by riffle location. Whiskers indicate \pm standard deviation. BR1 signifies Brown trout Riffle 1, RR1 signifies Rainbow trout Riffle $1 . \ldots \ldots \ldots$. . . . . .

4.5 Averages of a) bed shear, b) shear velocity, c) grain shear Reynolds number, and d) critical particle size stratified by riffle location. Whiskers indicate \pm standard deviation. . . . . . . . . . . . . . . . . 49

4.6 Mean turbulent kinetic energy per unit area of streambed stratified by riffle location. Whiskers indicate \pm standard deviation. . . . . . .

4.7 HEC-RAS ${ }^{\circledR}$ predicted nose-level velocities, where $u_{f}=\bar{u}(0.075)$, at study sites a) BR1, b) RR1, c) BR2, and d) RR3, superimposed by critical swimming speeds of brown trout- $u_{c r i t, b}$ and rainbow trout$u_{c r i t, r}$. Arrows indicate likely time of spawning, based on field survey. 51

4.8 Average velocity from $1.6 \mathrm{~cm}$ above the streambed $\left(u_{1.6}\right)$, stratified by riffle location. Whiskers indicate \pm standard deviation. . . . . . .

4.9 Interflow and hyporheic exchange within the longitudinal form of the tailspill. Modified from Cooper [1965], Vaux [1968], Thibeaux and Boyle [1987], Elliott and Brooks [1997a,b], Packman et al. [1997], and Wörman et al. [2002]. . . . . . . . . . . . . . . . . 
4.10 Illustration of circular flow within the pit as proposed by Hobbs [1937], Burner [1951] and Reiser [1976]. . . . . . . . . . .

4.11 Averages of profile vertical velocity standard deviation stratified by riffle location. Whiskers indicate \pm standard deviation. . . . . . . .

4.12 Longitudinal trend for Whiteman's creek as predicted by HEC-RAS ${ }^{\circledR}$. Total velocity, total shear, and unit stream power per unit area were modeled from $0 \leq Q \leq Q_{100}$ at 100 equal event discharges. Box limits are \pm standard deviation; whisker limits are minimum and maximum values. Locations of study sites are indicated. . . . . . . . .

4.13 Longitudinal trend for Whiteman's creek as predicted by HEC-RAS ${ }^{\circledR}$. a) Channel shear and b) channel Froude Number were modeled from $0 \leq Q \leq Q_{100}$ at 100 equal event discharges. Box limits are \pm standard deviation; whisker limits are minimum and maximum values. Locations of study sites are indicated. c) Study reach longitudinal profile. . . . . . . . . . . . . . . . .

4.14 Longitudinal trend for Whiteman's creek as predicted by HEC-RAS ${ }^{\circledR}$. a) Channel velocity was modeled from $0 \leq Q \leq Q_{100}$ at 100 equal event discharges. Box limits are \pm standard deviation; whisker limits are minimum and maximum values. Locations of study sites are indicated. b) Predicted channel velocity at $Q=Q_{b f}, Q=5.55 \mathrm{~m}^{3} / \mathrm{s}$, and $Q=2.33 \mathrm{~m}^{3} / \mathrm{s}-$ corresponding to the discharges experienced during PCADP sampling periods. c) Riffle-scale composite habitat index calculated from HEC-RAS ${ }^{\circledR}$ predicted channel velocity and shear at $Q=Q_{b f}, Q=5.55 \mathrm{~m}^{3} / \mathrm{s}$, and $Q=2.33 \mathrm{~m}^{3} / \mathrm{s} . \ldots \ldots$

4.15 Brown and rainbow trout Weighted Usable Area at Whiteman's Creek. $Q_{\max }$ is the discharge related to the maximum wadeable velocity. . . . . . . . . . . . . . . . . .

4.16 Comparison of HEC-RAS ${ }^{\circledR}$ predictions to a) mean measured velocity, b) mean measured bed shear, c) Reynolds number, and d) Froude number, at each study riffle at experienced discharge (BR1, $\left.\mathrm{BR} 2-Q=5.55 \mathrm{~m}^{3} / \mathrm{s} ; \mathrm{RR} 1, \mathrm{RR} 3-Q=2.33 \mathrm{~m}^{3} / \mathrm{s}\right)$. Box indicates \pm standard deviation. Whiskers indicate minimum/maximum measured values. . . . . . . . . . . . . . . .

4.17 Mean profile velocity surrounding brown trout redds at $Q \approx 5.55 \mathrm{~m}^{3} / \mathrm{s}$. a) Riffle 1 and b) Riffle 2. Ellipse(s) — redd (pit and tailspill) location(s); Dashed lines - Abandoned redd construction. . . . . . . . 64

4.18 Mean profile velocity surrounding rainbow trout redds at $Q \approx 2.33 \mathrm{~m}^{3} / \mathrm{s}$.

a) Riffle 1 and b) Riffle 3. Ellipse - redd (pit and tailspill) location.

4.19 Froude number surrounding brown trout redds at $Q \approx 5.55 \mathrm{~m}^{3} / \mathrm{s}$. a) Riffle 1 and b) Riffle 2. Ellipse(s) - redd (pit and tailspill) location(s); Dashed lines-Abandoned redd construction. . . . . . . . . . . 
4.20 Froude number surrounding rainbow trout redds at $Q \approx 2.33 \mathrm{~m}^{3} / \mathrm{s}$. a) Riffle 1 and b) Riffle 3 . Ellipse - redd (pit and tailspill) location. 67

4.21 Reynolds number surrounding brown trout redds at $Q \approx 5.55 \mathrm{~m}^{3} / \mathrm{s}$. a) Riffle 1 and b) Riffle 2. Ellipse(s) — redd (pit and tailspill) location(s); Dashed lines - Abandoned redd construction. . . . . . . . .

4.22 Reynolds number surrounding rainbow trout redds at $Q \approx 2.33 \mathrm{~m}^{3} / \mathrm{s}$. a) Riffle 1 and b) Riffle 3. Ellipse - redd (pit and tailspill) location.

4.23 Turbulent kinetic energy per unit area surrounding brown trout redds at $Q \approx 5.55 \mathrm{~m}^{3} / \mathrm{s}$. a) Riffle 1 and b) Riffle 2. Ellipse(s) - redd (pit and tailspill) location(s); Dashed lines-Abandoned redd construction. 70

4.24 Turbulent kinetic energy per unit area surrounding rainbow trout redds at $Q \approx 2.33 \mathrm{~m}^{3} / \mathrm{s}$. a) Riffle 1 and b) Riffle 3. Ellipse - redd (pit and tailspill) location. . . . . . . . . . . .

4.25 Bed shear surrounding brown trout redds at $Q \approx 5.55 \mathrm{~m}^{3} / \mathrm{s}$. a) Riffle 1 and b) Riffle 2. Ellipse(s) - redd (pit and tailspill) location(s); Dashed lines - Abandoned redd construction. . . . . . . . . . . .

4.26 Bed shear surrounding rainbow trout redds at $Q \approx 2.33 \mathrm{~m}^{3} / \mathrm{s}$. a) Riffle 1 and b) Riffle 3. Ellipse - redd (pit and tailspill) location. . .

4.27 Composite suitability index surrounding brown trout redds at $Q \approx$ $5.55 \mathrm{~m}^{3} / \mathrm{s}$. a) Riffle 1 and b) Riffle 2. Ellipse(s) — redd (pit and tailspill) location(s); Dashed lines - Abandoned redd construction. .

4.28 Composite suitability index surrounding rainbow trout redds at $Q \approx$ $2.33 \mathrm{~m}^{3} / \mathrm{s}$. a) Riffle 1 and b) Riffle 3 . Ellipse - redd (pit and tailspill) location. . . . . . . . . . . . . . 


\section{Symbols and Nomenclature}

\begin{tabular}{|c|c|c|}
\hline$A$ & cross-sectional flow area & $L^{2}$ \\
\hline$A_{i}$ & surface area of cell $i$ (for WUA analysis) & $L^{2}$ \\
\hline$A_{d}$ & effective catchment area & $L^{2}$ \\
\hline$A I$ & PCADP averaging interval & $T$ \\
\hline$B D$ & PCADP blanking distance & $L$ \\
\hline$B L$ & fish body length & $L$ \\
\hline$C_{D}$ & drag coefficient & - \\
\hline$C_{i}$ & composite suitability index of cell $i$ (for WUA analysis) & - \\
\hline$C_{d}$ & substrate-size suitability factor (for WUA analysis) & - \\
\hline$C_{h}$ & flow depth suitability factor (for WUA analysis) & - \\
\hline$C_{T}$ & temperature suitability factor (for WUA analysis) & - \\
\hline$C_{u}$ & velocity suitability factor (for WUA analysis) & - \\
\hline$C_{n}$ & Bray coefficient, equivalent to $k_{s} / d_{n}$ & - \\
\hline$C S$ & PCADP cell size & $L$ \\
\hline$d$ & particle size & $L$ \\
\hline$d_{c}$ & critical particle diameter & $L$ \\
\hline$d_{c, \max }$ & maximum critical particle diameter & $L$ \\
\hline$d_{n}$ & grain size at which $n \%$ of the sample is finer & $L$ \\
\hline $\bar{e}$ & mean turbulent kinetic energy per unit mass & $L^{2} T^{-2}$ \\
\hline $\bar{e}_{a}$ & mean turbulent kinetic energy per unit area & $M T^{-2}$ \\
\hline$f$ & Darcy-Weisbach friction factor & - \\
\hline$f_{i}$ & fredle index & $L$ \\
\hline$F_{r}$ & Froude number & - \\
\hline$g$ & gravitational acceleration $\approx 9.81 \mathrm{~m} / \mathrm{s}^{2}$ & $L T^{-2}$ \\
\hline$G$ & specific gravity $\approx 2.65$ & - \\
\hline$h$ & flow depth & $L$ \\
\hline$h_{b f}$ & bankfull depth & $L$ \\
\hline$h_{p}$ & velocity profile height & $L$ \\
\hline$k_{s}$ & surface roughness & $L$ \\
\hline$l$ & characteristic length & $L$ \\
\hline$n$ & Manning coefficient of roughness & $T L^{-1 / 3}$ \\
\hline$n_{l}$ & local Manning coefficient of roughness & $T L^{-1 / 3}$ \\
\hline$P R I$ & PCADP profile interval & $T$ \\
\hline
\end{tabular}




\begin{tabular}{|c|c|c|}
\hline$Q$ & total discharge & $L^{3} T^{-1}$ \\
\hline $\bar{Q}$ & mean daily discharge & $L^{3} T^{-1}$ \\
\hline$Q_{b f}$ & bankfull discharge & $L^{3} T^{-1}$ \\
\hline$Q_{s}$ & total sediment discharge & $M T^{-1}$ \\
\hline$R$ & hydraulic radius & $L$ \\
\hline$R_{e}$ & Reynolds number & - \\
\hline$R_{e *}$ & grain shear Reynolds number & - \\
\hline$s_{g}$ & Trask's sorting index & - \\
\hline$S_{I}$ & Inman's [1952] sorting coefficient & $\Phi$-units \\
\hline$S_{F W}$ & Folk and Ward's [1957] sorting coefficient & $\Phi$-units \\
\hline$S_{f}$ & friction slope & - \\
\hline$S_{0}$ & bed slope & - \\
\hline$t$ & time & $T$ \\
\hline$T$ & temperature & ${ }^{\circ} \mathrm{C}$ \\
\hline$u$ & velocity & $L T^{-1}$ \\
\hline $\bar{u}$ & time-averaged velocity & $L T^{-1}$ \\
\hline$u_{\text {crit }}$ & fish critical swimming velocity & $L T^{-1}$ \\
\hline$u_{f}$ & fish nose-level velocity & $L T^{-1}$ \\
\hline$u_{s}$ & fall velocity & $L T^{-1}$ \\
\hline$u_{*}$ & shear velocity & $L T^{-1}$ \\
\hline$u_{* c}$ & critical shear velocity & $L T^{-1}$ \\
\hline$u_{1.6}$ & skin velocity $1.6 \mathrm{~cm}$ above stream bed & $L T^{-1}$ \\
\hline$U$ & depth-averaged velocity & $L T^{-1}$ \\
\hline$U_{c}$ & critical depth-averaged velocity & $L T^{-1}$ \\
\hline$U_{p}$ & mean PCADP profile velocity & $L T^{-1}$ \\
\hline$w$ & width & $L$ \\
\hline & bankfull width & $L$ \\
\hline$W U A$ & weighted usable area & $L$ \\
\hline$x_{e}$ & Einstein-Keulegan correction factor & - \\
\hline$z$ & height above streambed & $L$ \\
\hline$z_{0}$ & roughness length & $L$ \\
\hline$\delta_{\nu}$ & viscous sublayer thickness & $L$ \\
\hline$\phi$ & angle of repose & $\circ$ \\
\hline$\Phi$ & particle size & $\Phi$-units \\
\hline$\gamma$ & specific weight of water, where $\gamma=\rho g$ & $M L^{-2} T^{-2}$ \\
\hline$\gamma_{s}$ & specific weight of sediments, where $\gamma_{s}=G \gamma$ & $M L^{-2} T^{-2}$ \\
\hline$\theta$ & Manning's unit conversion factor & - \\
\hline$\kappa$ & von Kármán constant $\approx 0.4$ & - \\
\hline$\Lambda$ & meander wavelength & $L$ \\
\hline$\mu$ & dynamic viscosity of water & $M L^{-1} T^{-1}$ \\
\hline$\nu$ & kinematic viscosity of water, where $\nu=\mu / \rho$ & $L^{2} T^{-1}$ \\
\hline$\rho$ & mass density of water $\approx 1000 \mathrm{~kg} / \mathrm{m}^{3}$ & $M L^{-3}$ \\
\hline$\rho_{s}$ & mass density of sediments $\approx 2650 \mathrm{~kg} / \mathrm{m}^{3}$ & $M L^{-3}$ \\
\hline
\end{tabular}


$\omega \quad$ stream power

$M L T^{-3}$

$\omega_{a} \quad$ unit stream power per unit area

$M T^{-3}$

$\omega_{w} \quad$ unit stream power per unit weight of water

$L T^{-1}$

$\Omega \quad$ sinuosity

$\sigma_{n} \quad$ standard deviation of velocity in the $n$-direction

$L T^{-1}$

$\tau_{c} \quad$ critical shear stress

$M L^{-1} T^{-2}$

$\tau_{r} \quad$ radial shear stress

$M L^{-1} T^{-2}$

$\tau_{0} \quad$ bed shear stress

$\tau_{0, \max }$

maximum bed shear stress

$M L^{-1} T^{-2}$

$\tau_{*}$

dimensionless shear stress/Shields entrainment function

$M L^{-1} T^{-2}$

$\tau_{* c} \quad$ critical dimensionless shear stress 


\section{Chapter 1}

\section{Introduction}

Over the past several centuries, mankind has altered watercourses and their associated floodplains for the purposes of flood regulation, transportation, recreation, irrigation, sanitation, and water consumption, among other reasons. Various efforts and methods to control the natural tendencies of watercourses have resulted in the degradation of river health, stability, and diversity (Tennant, 1976; Poff et al., 1997; Bunn and Arthrington, 2002; Champoux et al., 2003). Today, scientists and engineers from a diverse suite of disciplines express the growing need to revert rivers back to their meandering, self-stabilizing, and biologically diverse dynamic equilibrium states to minimize long-term maintenance and environmental impacts and to improve aquatic health (Newbury and Gaboury, 1993; Naiman et al., 2002; Wheaton et al., 2004a).

As both biotic and abiotic research has progressed in the study of watercourses, it is widely recognized that a collaborative effort amongst many scientific, engineering, and social disciplines must be incorporated into lotic system research (i.e., the study of biophysical processes in running waters) to provide effective rehabilitation strategies (Maddock, 1999; Schwartz and Herricks, 2007). Imhof et al. [1996] stress the need to evaluate lotic systems at multiple spatial and temporal scales to characterize channel form and function. They identified that stream health is characterized by the channel's geomorphological function at large scales anywhere from the sub-basin to the river-reach scale, which they regard as the top-down approach. Conversely, the investigation of river function as it pertains to hydraulic processes, channel shear, sediment transport, and biodiversity are small-scale processes and is thus regarded as a bottom-up approach.

A top-down evaluation of river health, from a landscape, watershed, and/or valley segment perspective, implicitly homogenizes the local-scale (e.g., reach to site) complexity that has revealed few predictable correlations in defining physical habitat. The investigation of the spawning habits of river-spawning salmonids provides a poignant example of the inherent difficulty in defining physical habitat from local-scale metrics. Much of the spawning studies reviewed in this thesis have relied on channel velocity, Reynolds Number, Froude Number, flow depth, temperature, 
bed material size, and water quality to define physical habitat. However, due to the spatial and temporal complexity of flowing waters and technological measurement limitations, channel forming processes and habitat complexity have been poorly coupled.

Physical scientists have long circumvented this issue of complexity by replacing fine-scale measurements by larger scale homogeneous metric representations to describe river processes. Examples of such simplifications include the velocity-area method (Buchanan and Somers, 1969) to quantify discharge and flow depth (crosssectional measurements), Manning's equation to estimate average cross-sectional channel velocity, Wolman's [1954] pebble count to represent substrate distribution, indicator species to represent aquatic diversity and health (Stratzner et al., 1988; Champoux et al., 2003), and habitat suitability indices to evaluate instream flow requirements at various discharge events (Raleigh at al., 1984, 1986).

Another common problem related to the physical metrics used in the study of rivers is the disparity between the data collected when characterizing fine-scale physical habitat and the data collected at flood flow conditions that define channel morphology and thus the physical habitat features. Biological data are typically collected during low flow seasons when rivers are wadable and the aquatic life is observable (Smith, 1973; Shirvel and Dungey, 1983; Witzel and MacCrimmon, 1983; Kondolf et al., 1993). In these conditions, the hydraulic, sedimentological, and geomorphological processes dictating river form, function, and hence habitat features are nominal. Conversly, measurements related to channel form and function are primarily measured during flood stages (i.e., bankfull discharge and larger) when the hydraulic and sedimentological processes are actively defining the channel geomorphology (Leopold et al., 1964). This disparity in temporal sampling strategies between biological and physical scientists inevitably results in disparite descriptions of the same physical system where harmony should exist.

The tendency of river spawning fishes to construct their redds in streambed substrate is a biophysical junction between small-scale processes and large-scale river form and function. The site specific selection process of a spawning fish is believed to be based upon the small scale physical and chemical conditions (Burner, 1951). However, one cannot neglect that the microhabitats that these fish select for spawning exists within a larger morphological feature (such as a run or a riffle) that has been formed by hydraulic and sediment transport processes during larger and less frequent discharge events.

Recent advances in high resolution three-dimensional flow measurement technology has provided an opportunity to study the hydrodynamic characteristics of redds and surrounding fluvial features in unprecedented detail. The spawning habitat of brown trout (Salmo trutta) and rainbow trout (Oncorhynchus mykiss) spawning beds will be measured and evaluated to identify if hydrodynamic properties exist which parametrically define spawning site selection. Data collected will also be used to evaluate the degree of homogeneity assumed when applying habitat suitability models at finer-scales; an emerging trend in spawning habitat rehabil- 
itation projects that is often criticized (Lamouroux and Souchon, 2002; Souchon and Capra, 2004). 


\section{Chapter 2}

\section{Background}

\subsection{Spawning and redd construction of salmon and trout}

The spawning process of salmon and trout has been described by Burner [1951], Briggs [1953], Jones and Ball [1954], Orcutt et al. [1968], Reiser [1976], Grost et al. [1991], and Kondolf et al. [1993] (Figure 2.1). Spawning begins with a female fish scanning the streambed for a suitable spawning location, a process referred to as the the pre-spawning stage (Burner, 1951). The female may carry out exploratory cutting (Jones and Ball, 1954; Grost et al., 1991), whereby the female, through vigorous movements of her tail, induces a negative pressure on the streambed surface (Kondolf et al., 1993), subsequently releasing sediment into the current and transporting the sediment downstream. If the female considers the site unsuitable, the site is abandoned and the process is repeated until a suitable spawning site is found (Jones and Ball, 1954; Chapman, 1988; Crisp and Carline, 1989). For example, Trush [1989] and Ortlepp and Mürle [2003] observed female fish abandoning potential redd sites when a layer of cemented bed material was encountered after initial cutting attempts.

Once a suitable site is chosen, the female fish cutting into the streambed leaves behind a semi-spherical depression, referred to as the pit (Figure 2.2). The pit provides a controlled area where the ova are laid and subsequently fertilized (Kondolf et al., 1993). After oviposition, the female proceeds to move immediately upstream, repeating the pit excavation process. By displacing sediment into the current, the freed coarse sediment is carried downstream covering the original excavated pit containing the fertilized ova while the finer suspended sediment is carried downstream beyond the limits of the redd (Kondolf et al., 1993). The freed loosened sediment covering the ova is referred to as the tailspill (Figure 2.2). The sequential process of pit excavation and tailspill development is repeated producing a finished redd composed of multiple successive pits, each immediately upstream of the previous. After the completion of the redd, the tailspill has an elongated or teardrop shape 


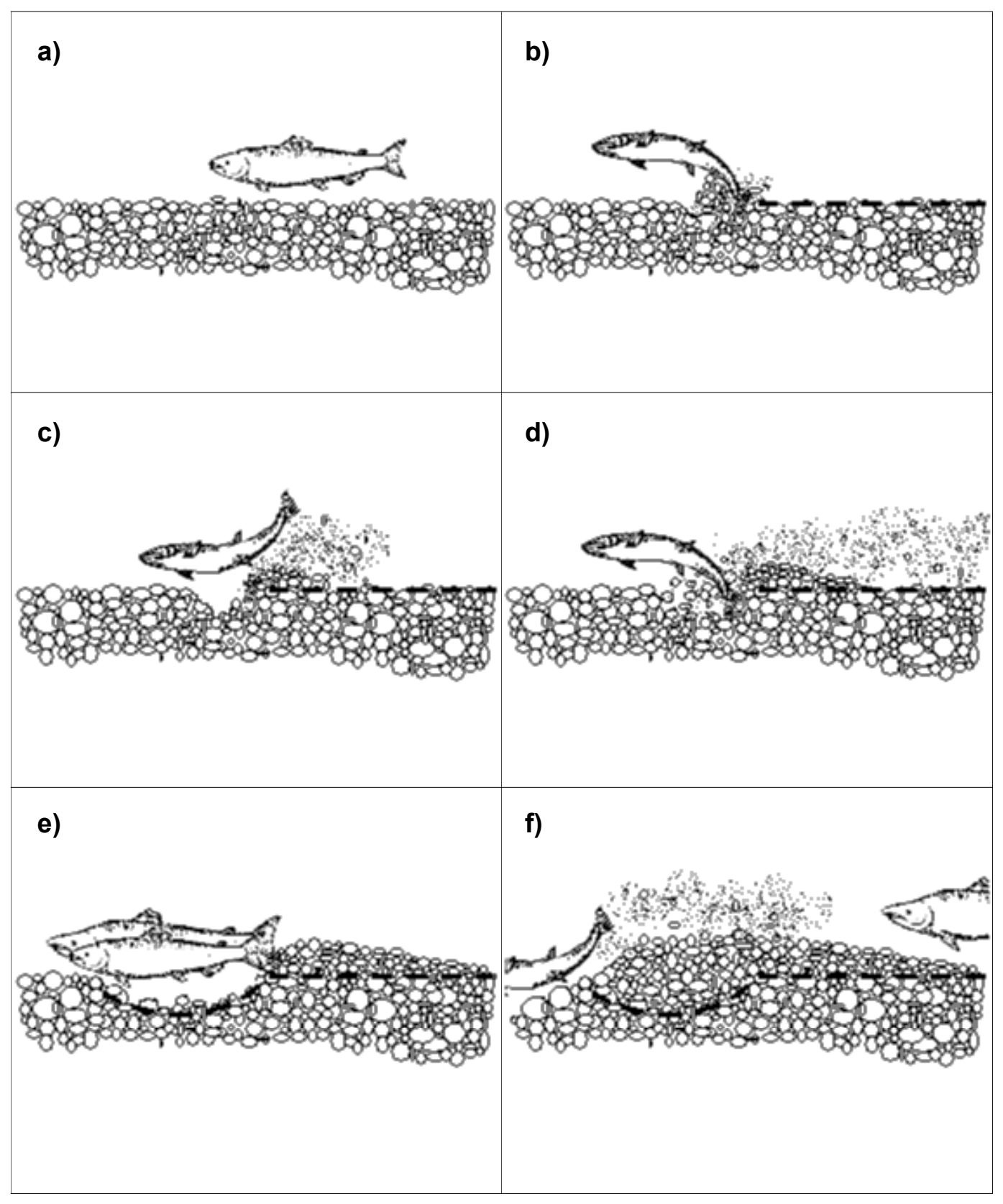

Figure 2.1: Spawning sequence of river-spawning salmon and trout. The dashed line indicates the limit of undisturbed streambed. a) Pre-spawning stage; b) cutting; c) displacement of streambed material; d) transport of fine-grained sediment downstream; e) oviposition; f) covering of fertilized ova and subsequent upstream pit excavation. Modified from Burner [1951]. 
that is readily identified in the field (Reiser, 1976; Ottaway et al., 1981; Shirvell and Dungey, 1983; Grost et al., 1990; Essington et al., 1998). Immediately following fertilization, the eggs undergo a series of brief bio-physical transformations including the doubling of volume with water adsorption (Gray, 1932; Hobbs, 1937; Zotin, 1958; Bonham, 1976). The fertilized eggs remain within the interstitial spaces until they emerge as fry from the confines of the tailspill months after the spawning process occurs. Fry emergence success rates, which is defined as fry emerged to ova laid, range between 50-80\% (Vaux, 1968; Beard and Carline, 1991), however, success has been observed exceeding 95\% (Hobbs, 1937; Jones and Ball, 1954; Phillips et al., 1975; Tappel and Bjornn, 1983; Witzel and MacCrimmon, 1983b).

a)

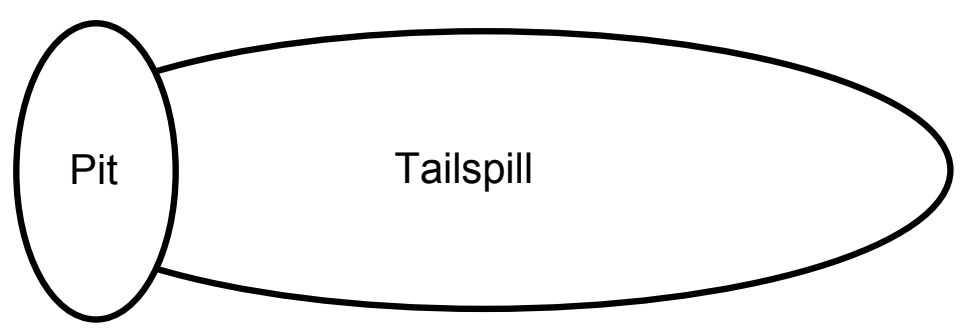

b)

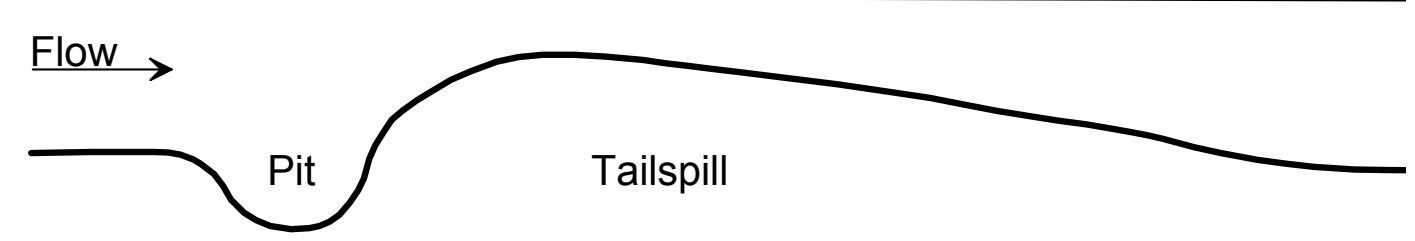

Figure 2.2: Typical layout of the redd form, constructed by both salmon and trout, in a) plan view and b) longitudinal profile view.

In contrast to the initial streambed conditions, the fine content of the redd substrate is significantly reduced during the construction process (Lotspeich \& Everest, 1981; Kondolf et al., 1993). From thirteen studies reviewed, Kondolf et al. [1993] found that the percentage of fines less than $1 \mathrm{~mm}$ in diameter were reduced by approximately $63 \%\left(r^{2}=0.93\right)$ of the initial streambed content prior to pit excavation. However, when comparing the substrate composition among redds or comparing redds to initial/undisturbed substrate composition, the literature failed to find any correlation (Orcutt et al., 1968; Reiser, 1976; Shirvell and Dungey, 1983; Witzel and MacCrimmon, 1983b; Sowden and Power, 1985; Crisp and Carline, 1989; Grost et al., 1990; Kondolf et al., 1993).

The relationship between the size of the spawning fish and redd sediment size is somewhat positively correlated, the only definite restriction being that fish are unable to construct redds in gravels with particle sizes greater than $10 \%$ of the spawning fish's body length (Kondolf and Wolman, 1993). However, Kondolf and Wolman [1993] stressed that the use of fish size to determine spawning location may be an inconsistent approach since smaller fish tend toward small tributaries of greater slope and sediment size, whereas larger fish will remain in mainstems of 
lesser slope and smaller particle sizes.

Substrate size preference for redd site selection has been widely evaluated among the reviewed studies, many of which are not consistent with engineering and geomorphic convention (Kondolf, 2000). Visual interpretation of sediment character has been employed by Burner [1951], Reiser [1976] and Essington et al. [1998]. Schmetterling [2000] used the Wolman Pebble count (Wolman, 1954), which, as noted by Kondolf [2000], is intended to evaluate the channel's surface roughness, not to describe sediment composition. Only Witzel and MacCrimmon [1983b], Sowden and Power [1985], Grost et al. [1991], Crisp and Carling [1989], and Ottaway et al. [1981] sieved dried samples through the engineering-standard phi classes (§3.2Friedman and Sanders, 1978). Kondolf [2000] also pointed out that many reports have excluded larger (armouring) rock sizes deemed immovable by the spawning fish (which typically lay at the base of the pits), in some cases without reporting the exclusion, causing a fine-bias to the reported substrate analysis.

Displacing sediment into the water column during streambed cutting reduces the sediment fine content since finer particles are carried the furthest downstream (Chapman, 1988; Grost et al., 1991; Kondolf et al., 1993; Kondolf and Wolman, 1993; Kondolf, 2000; Schmetterling, 2000; Zimmermann and Lapointe, 2005). The distance and rate of particle deposition downstream is related to turbulent mixing and the particles' fall velocity. The fall velocity for a spherical particle of diameter $d$ in clear water can be approximated by (Julien, 1998; Sturm, 2001)

$$
u_{s}=\sqrt{\frac{\frac{4}{3}\left(\frac{\gamma_{s}}{\gamma}-1\right) g d}{C_{D}}},
$$

$$
\text { where } \begin{aligned}
u_{s} & =\text { fall velocity }\left[L T^{-1}\right] \\
g & =\text { gravitational acceleration }\left[L T^{-2}\right] \\
d & =\text { sediment size }[L] \\
C_{D} & =\text { drag coefficient }[-] ; \\
\gamma, \gamma_{s} & =\text { specific weight of water and sediment }\left[M L^{-2} T^{-2}\right] .
\end{aligned}
$$

For particles $d \geq 1 \mathrm{~mm}, C_{D}=1.5$, the fall velocity can be approximated by (Julien, 1998)

$$
\begin{gathered}
u_{s} \cong \sqrt{(G-1) g d} ; \\
G=\frac{\gamma_{s}}{\gamma}=\frac{\rho_{s}}{\rho}=2.65,
\end{gathered}
$$

where $G=$ specific gravity $[-]$; $\rho, \rho_{s}=$ mass density of water and sediment $\left[M L^{-3}\right]$.

The presence of fines, $d<1 \mathrm{~mm}$, within the tailspill is the greatest cause of fry mortality (Hobbs, 1937; Wickett, 1954; Cooper, 1965; Vaux, 1968; Phillips et al., 
1975; Lotspeich and Everest, 1981). Fines within the tailspill restricts the interstitial flow, reducing both dissolved oxygen and nutrient supply while restricting the removal of metabolic wastes (Stuart, 1953a,b; Wickett, 1954; Vaux, 1968; Reiser, 1976; Sowden and Power, 1985). Fine-removal efficiency during redd construction increases with increasing stream velocity; hence, brown and rainbow trout, which tend to spawn along swifter flowing riffles (Hayes, 1987; Lisle, 1989; Trush, 1989), construct their redds with a larger reduction in fines compared to brook trout (Salvelinus fontinalis), a species of the charr family who do not have the same spawning strategy as salmon and trout as they spawn in slower flowing pools and lake shores (Reiser, 1976; Witzel and MacCrimmon, 1983a,b; Blanchfield and Ridgeway, 1997; Essington et al., 1998; Bernier-Bourgault and Magnan, 2002).

Salmon and trout seasonally returning to spawning sites continually keep the sediments free of fines and relatively loose for ease of redd construction (Chapman, 1988); similarly, Orcutt et al. [1968] noted spawning fish attracted to artificially loosened gravel. Redd superimposition is the act of fish, either inter- or intraspecifically, constructing their redds over existing redds, destroying the previously laid ova, and further indicating that streambed disturbance attracts spawning fish (Hayes, 1987). Burner [1951], Hayes [1987], and Beard and Carline [1991] found that population density cannot be correlated with the degree of superimposition; Essington et al. [1998] found that one-third of their redds were superimposed, while many seemingly suitable sites remained untouched. They contend that there may be behavioural ties to redd-site selection associated with fish openly choosing areas deemed suitable by other spawning fish. Thus, superimposition will assure the spawning fish that the site selected will have reduced fines and may be re-excavated with relative ease (Hayes, 1987). Superimposition has also been identified in the works of Hobbs [1937], Reiser [1976], Bernier-Bourgault and Magnan [2002], and Curry and Noakes [1995].

\subsection{The selection of suitable redd sites}

The physical characterization of redd site selection typically involves local velocity and depth measurements, sediment analysis, and/or the detection of groundwater seepage. Of the literature reviewed, none could consistently define a physical attribute, or a combination of attributes, that directly linked salmon and trout to their spawning grounds.

Dimensionless fluid ratios that describe the character of flow are used in lotic ecology to investigate a wide range of environmental attributes, from microhabitats to population densities and the evolved adaptations of aquatic organisms (Leopold and Maddock, 1953; Statzner et al., 1988; Davis and Barmuta, 1989; Jowett, 1993; Newbury and Gaboury, 1993; Vogel, 1994; Allen, 1995; Giller and Malmqvist, 1998; Wadeson and Rowntree, 1998; Rempel et al., 2000; Lamouroux and Capra, 2002). The Reynolds number $\left(R_{e}\right)$ is the ratio of inertial forces to viscous forces and is 
defined as

$$
R_{e}=\frac{u l}{\nu}
$$

$$
\text { where } \begin{aligned}
u & =\text { velocity }\left[L T^{-1}\right] \\
l & =\text { characteristic length }[L] \\
\nu & =\text { kinematic viscosity }\left[L^{2} T^{-1}\right] .
\end{aligned}
$$

For shallow/wide natural channels the representative velocity is taken as the depth-averaged velocity $(u=U)$, and the characteristic length $(l)$ as the flow depth ( $h$, i.e., $l=h$ ) (Vogel, 1994; Julien, 1998). For open channel flow, turbulent conditions occur once $R_{e}>2500$ (Knighton, 1998), where

$$
R_{e}=\frac{U h}{\nu}
$$

The Froude number $\left(F_{r}\right)$ defines the ratio of a fluid's inertial forces to gravitational forces and is used to assess the tranquillity of flow (Leopold and Maddock, 1953) and is commonly used in defining physical habitat (Statzner et al., 1988). Flow is characterized as sub-critical when $F_{r}<1$ and super-critical when $F_{r}>1$. Expected Froude numbers among mild-slope gravel-bed riffles at low flow conditions are $F_{r}>0.4$ (Jowett, 1993). For steady flow conditions (Julien, 1998),

$$
F_{r}=\frac{U}{\sqrt{g h}}
$$

Figure 2.3 summarizes Reynolds and Froude numbers measured proximal to brown trout and rainbow trout redds using the data collected and presented in Table 2.1. The velocities reported in Table 2.1 are highly variable both within and amongst studies. In all cases, the velocity measurements are made using onedimensional current meters with the exception of Zimmer and Power [2006], who calculated their redd site velocities using Manning's equation for uniform flow based on the channel dimensions immediately upstream of the located redds. The Manning's equation defined as

$$
U=\frac{\theta}{n} R^{\frac{2}{3}} S_{f}^{\frac{1}{2}}
$$

where $\theta=$ unit conversion factor (S.I. $\theta=1$, Imperial $\theta=1.49$ );

$n=$ Manning coefficient of roughness;

$R=$ hydraulic radius, $R \approx h$ for wide-shallow channels $[L]$;

$S_{f}=$ friction slope $[L / L]$.

The methods employed when measuring velocity were inconsistent. Most determined mean velocity at $z=0.4 h$, where $z$ is the height above the streambed. Others measured velocity at $z=10 \mathrm{~cm}$ (Orcutt et al., 1968; Smith, 1973; Witzel and MacCrimmon, 1983a; Bernier-Bourgault and Magnan, 2002), or at $z=5 \mathrm{~cm}$ (Ottaway et al., 1981; Sorenson et al., 1995), which is said to coincide with the depth at which 


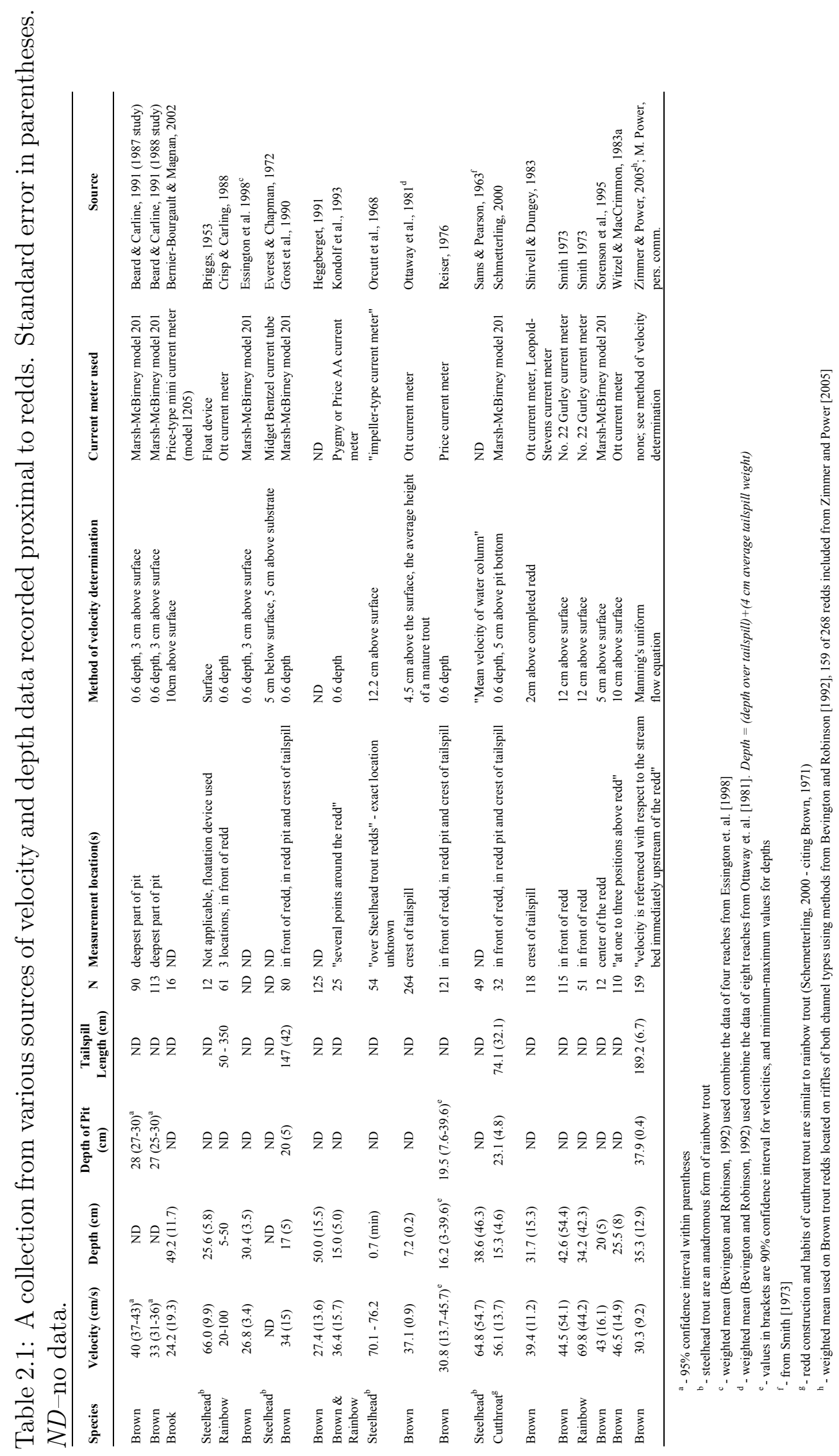


the velocity most influences the fish's ability to hold station, otherwise known as the nose-level velocity (Ottaway et al., 1981). Grost et al. [1990] acknowledged that no matter the methods used or the variability of the results, spawning salmon and trout consistently avoid low velocity regions, where $u_{\min } \approx 20 \mathrm{~cm} / \mathrm{s}$.

The influence of groundwater discharge with the selection of spawning sites has long been recognized, however, its presence is rarely measured (Blanchfield and Ridgway, 1996). Groundwater upwelling is thought to supply the interstitial flow necessary for embryonic survival (Hansen, 1975). The presence of groundwater, however are known to be chosen only by a certain subset of salmonids, such as brook trout (Witzel and MacCrimmon, 1983a; Blanchfield and Ridgway, 1997; Essington et al., 1998; Bernier-Bourgault and Magnan, 2002).

Spatial distribution of groundwater seepage can vary highly within short distances; for example, depending on the local geology, Conant [2001] found that groundwater fluxes ranged $0.03 \mathrm{~L} / \mathrm{m}^{2} \mathrm{~d}$ to at least $446 \mathrm{~L} / \mathrm{m}^{2} \mathrm{~d}$ along a single study riffle. The presence of groundwater, however, does have an effect on the temperature present within the redd, which affects the dissolved oxygen content (Sawyer et al., 1994). Dissolved oxygen, subsequently, relates to the time required for fry development and subsequent emergence (Hobbs, 1937; Hansen, 1975; Kondolf, 2000). Significant fry mortality occurs once dissolved oxygen concentrations fall below 5 mg/L (Sowden and Power, 1985).

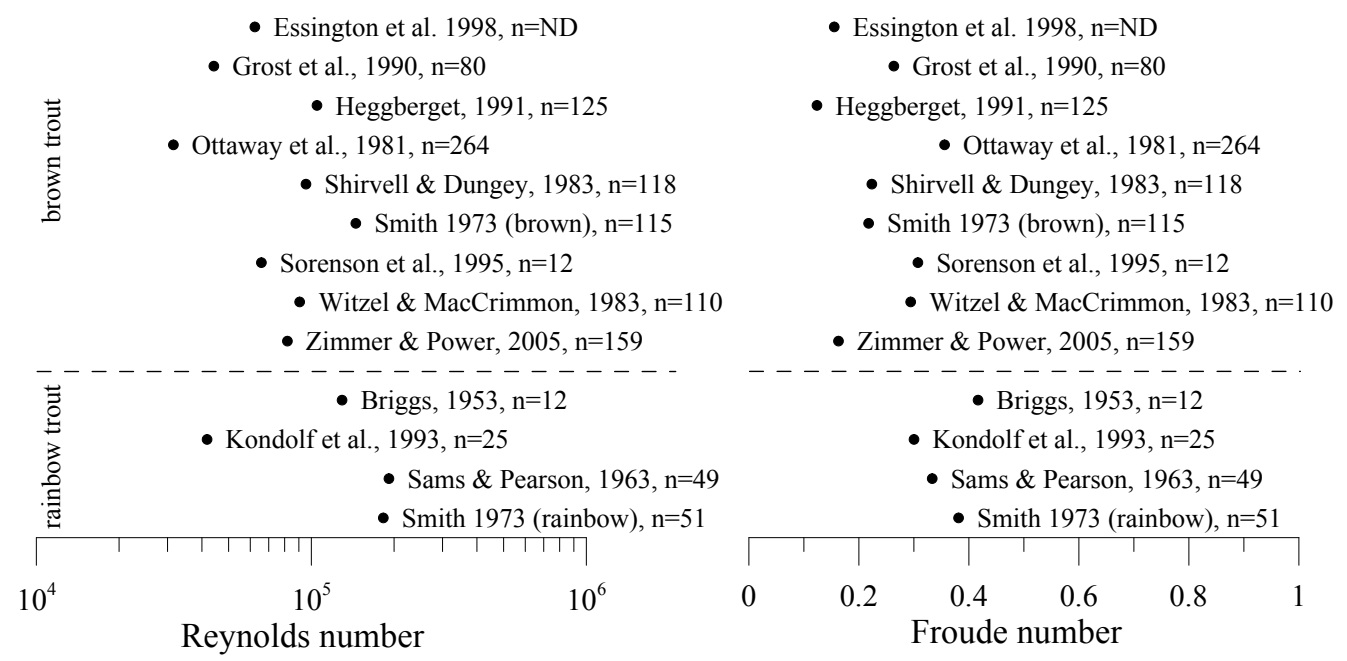

Figure 2.3: Reynolds and Froude numbers proximal to brown trout and rainbow trout redds reported from fifteen studies.

Lotspeich and Everest [1981] and Witzel and MacCrimmon [1983a] surmised that woody debris is preferred by salmon and trout when choosing their spawning locations. Reiser [1976] and Zimmer and Power [2006] attempted to relate cover to spawning habits by noting the presence of cover above or immediately adjacent to a redd. Reiser [1976] found that $40 \%$ of brown trout redds were constructed within 1-10 $\mathrm{m}$ of cover; however, he also mentioned that this was inconclusive since the 
type of cover varied highly within his study. Zimmer and Power [2006] found that cover was mostly associated with larger fish who choose to develop their redds at non-preferred locations.

Attempts have also been made to correlate redd-site selection to channel bed slope (Shirvell and Dungey, 1983; Witzel and MacCrimmon, 1983a; Hayes, 1987; Beard and Carline, 1991; Lisle and Lewis, 1992; Schmetterling, 2000; Zimmer and Power, 2006), yet no successful correlations were identified. In addition, Beard and Carline [1991] studied a highly active spawning reach where the bed slope was compared to redd density, again, no correlation was found. Other channel features that have been examined are water surface slope by Kondolf et al. [1993] and channel width by Schmetterling [2000]. All results show that no statistically significant correlation between these metrics and redd site selection exists.

\subsubsection{Redds in high-flow conditions}

Hobbs [1937] studied naturally constructed salmon redds through a winter flood event in the New Zealand with an approximate fifty-year return period, where flow depths came close to $3 \mathrm{~m}$ above base levels. Once the flooding subsided, he noted that fewer redds were damaged due to erosion than due to excess fine deposition. Hobbs [1937] also observed additional redds that were constructed during the high flow event, including some in areas on the floodplain. In contrast, both Lisle [1989] and Trush [1989] observed significant redd damage due to high flow events, although Lisle [1989] maintained that not all spawning sites were at risk. In their conclusions, Lisle [1989] and Trush [1989], and later acknowledged by Bunn and Arthington [2002] and Wheaton et al. [2004a], surmised that salmonids should, in the long run, benefit from major storm events since heavy sediment discharge will provide a renewed clean gravel optimal for spawning. Ortlepp and Mürle [2003] studied the effects of a flood program designed to promote the habitat of aquatic life downstream of two reservoirs built in Switzerland in the 1960s. Because of the reduction in high-flow events, there had been substantial deposition of fines kilometres downstream of the sites. Soon after the flood program was initiated, redd development increased three-fold in three years, while fish mortalities associated with the induced flooding never exceeded $2 \%$. High velocities were common to preferred spawning locations.

In the event of flows approaching effective discharge, Ottaway et al. [1981], Crisp and Carline [1989], and DeVries [1997] surmised that scour to the redd may not be detrimental to the ova since the deposited eggs are typically situated below the original streambed grade. Salmonids naturally spawn during wetter seasons (Cooper, 1965; Lisle, 1989; Lisle and Lewis, 1992; Kondolf et al., 1993), while the ova incubate through low-flow seasons (Cooper, 1965; Kondolf et al., 1993). Kondolf et al. [1993] acknowledged further that salmonids over the long-term have prospered in many flow conditions, and are limited only by velocities at which the fish can hold station. 
Station holding, defined as the ability of fish to maintain a cruising swimming speed equivalent to local channel velocities, otherwise known as the steady sustained swimming speed, is dependent on the body length of the fish (BL), water temperature, pH, and dissolved oxygen content (Jones, 1971; Hoar and Randall, 1978; Butler et al., 1992). Fishes' maximum swimming velocity without showing notable fatigue is known as the swimming critical velocity $\left(u_{\text {crit }}\right.$-Hoar and Randall, 1978). From fourteen sources, observing $n=217$ fish, Hoar and Randall [1978] showed that the $u_{\text {crit }}$ for rainbow trout is approximately $3.6 \mathrm{BL} / \mathrm{s}$. Rainbow trout, on average, spawn at age-5, at which point they typically reach a body length of $660 \mathrm{~mm}$ in Southern Ontario (Scott and Crossman, 1998); thus, for spawning rainbow trout, $u_{\text {crit }, r} \approx 2.34 \mathrm{~m} / \mathrm{s}$. The $u_{\text {crit }}$ for brown trout varies depending on sources: $u_{\text {crit }}=1.6-2.3 \mathrm{BL} / \mathrm{s}$, sustained for $30 \mathrm{~min}$ (Bainbridge, 1962); $u_{\text {crit }}=4.5$ $\mathrm{BL} / \mathrm{s}$ sustained for 7 days (Davidson and Golspink, 1977); $u_{\text {crit }}=2.7 \mathrm{BL} / \mathrm{s}$ (Hoar and Randall, 1978); $u_{\text {crit }}=2.21 \mathrm{BL} / \mathrm{s}$ (Butler and Day, 1993); and, $u_{\text {crit }}=2.3$ $\mathrm{BL} / \mathrm{s}$ at $5^{\circ} \mathrm{C}, u_{\text {crit }}=2.4 \mathrm{BL} / \mathrm{s}$ at $15^{\circ} \mathrm{C}$ (Day and Butler, 1996). For the purposes of this thesis, the average value of $u_{c r i t}=2.7 \mathrm{BL} / \mathrm{s}$ is considered. The body length of a Southern Ontario spawning brown trout is approximately $430 \mathrm{~mm}$ (Scott and Crossman, 1998), yielding a brown trout critical velocity of $u_{c r i t, b}=1.17 \mathrm{~m} / \mathrm{s}$.

\subsubsection{Habitat Suitability Curves}

USGS [2001] defines a physical habitat as "a combination of hydraulic and/or physical variables such as, depth, velocity, substrate, and cover at a spatial scale of near zero to a few meters." For many indicator species used in assessing stream health, USGS [2001] defined physical habitat based upon univariate habitat suitability curves that relate indicator species' environmental preference to physical hydraulic measures. These habitat suitability curves represent relationships amongst depth, velocity, and measured channel index (vaguely defined as substrate and cover characteristics), to microhabitat preferences for target species at specific life stages (USGS, 2001). The habitat suitability index incorporated in the Instream Flow Incremental Methodology (IFIM-Bovee, 1982) for spawning brown trout (Raleigh et al., 1986) and spawning rainbow trout (Raleigh et al., 1984) is based on four input variables that are shown in Figure 2.4.

Instream flow stewardship, which has historically been based on minimum flow targets, has since been forced to add geomorphology and hydrology to the definition of physical habitat since minimum flow targets neglect natural flow regimes (Maddock, 1999; Annear et al., 2004). As a result, the implementation of the IFIM has been the preferred methodology worldwide (Souchon and Capra, 2004). The IFIM was originally intended to provide artificial flow regimes downstream of dams and reservoirs where minimum flow targets proved detrimental to lotic ecology (Maddock, 1999; Annear et al., 2004). IFIM integrates the planning of water supply with

one-dimensional hydraulic models at varying flow conditions coupled with physical habitat suitability indices for the indicator species of interest (USGS, 2001). 
As a component of the IFIM, the Physical Habitat Simulation System (PHABSIM) is the one-dimensional hydraulic model that determines reach-scale habitat preferences in relation to varying flow conditions based on the four input variables of Figure 2.4 (Raleigh et al., 1984, 1986; Waddle, 2001; Lamouroux and Souchon, 2002). PHABSIM's generalized physical habitat outputs are in the form of a Weighted Usable Area (WUA — which quantifies habitat availability per reach length) calculated at multiple discharges simulated using PHABSIM. WUA is defined as (Waddle, 2001)

$$
W U A=\frac{\sum_{i=0}^{n} A_{i} \cdot C_{i}}{\text { reach length }}
$$

where $W U A=$ Weighted usable area $\left[L^{2} / L\right]$;

$A_{i} \quad=$ the surface area of cell $i\left[L^{2}\right]$;

$C_{i}=$ the composite suitability for cell $i[-]$.

The composite suitability is an index between 0 and 1 describing the weighted availability of physical habitat for a given sample area, where 0 is unusable and 1 is most optimal. The composite suitability combines mean velocity, depth, and channel index (vaguely defined in Waddle [2001] as simply "cover and substrate") calculated at discreet points along the channel's cross-section, in a similar fashion to the velocity-area method of Buchanan and Somers [1969]. For spawning brown and rainbow trout, Raleigh et al. [1984,1986] has replaced the channel index with temperature and substrate size curves shown in Figure 2.4. The composite suitability index can be determined by either these three methods (Waddle, 2001):

The composite suitability index $\left(C_{i}\right)$ is most commonly defined as

$$
C_{i}=C_{u} \cdot C_{h} \cdot C_{d} \cdot C_{T}
$$

An alternative method of determining $C_{i}$ is based upon the geometric mean method that reduces the sensitivity of the composite suitability to individual suitability factors, where

$$
C_{i}=\sqrt[4]{C_{u} \cdot C_{h} \cdot C_{d} \cdot C_{T}}
$$

A third method is the limiting individual suitability factor, where

$$
C_{i}=\min \left(C_{u}, C_{h}, C_{d}, C_{T}\right)
$$

where $C_{u}=$ the velocity suitability factor (Figure 2.4a) [-];

$C_{h}=$ the depth suitability factor (Figure 2.4b) [-];

$C_{d}=$ the substrate suitability factor (Figure 2.4c) [-];

$C_{T}=$ the temperature suitability factor (Figure 2.4d) [-]. 
The simplicity of PHABSIM's inputs used to describe physical habitat has gained much criticism, especially by Souchon and Capra [2004] who were able to predict PHABSIM's WUA outputs using empirically-measured Reynolds and Froude numbers measured at multiple discharges. Other criticism points toward the application of habitat suitability curves, which, originally intended for reach-scale assessments, are applied at smaller scales in conjunction with multi-dimensional hydraulic models (Lamouroux and Souchon, 2002; Souchon and Capra, 2004). Although reach-scale habitat preference can be extended regionally (Lamouroux et al., 1999), the performance of multivariate models are regionally-dependent, a fact that has been overlooked (Lamouroux et al., 1998; Maddock, 1999). Crowder and Diplas [2000] add that when multi-dimensional models are used by researchers, many have excluded natural obstructions such as boulders and large wooded debris when simulating microhabitats, the very obstructions known to induce the preferred physical habitat for a wide range of lotic species. In addition, with regards to two-dimensional hydraulic modelling, Crowder and Diplas [2000] note that "substantial research remains to be performed to determine the accuracy with which one can predict the complex flow patterns that natural streams exhibit." Other documented criticisms of PHABSIM include: the inadequacy of point measurements used in defining reach-scale characteristics (Statzner et al., 1988; Crowder and Diplas, 2000; Souchon and Capra, 2004); the predictability of habitat suitability using averaged reach-scale channel characteristics such as $Q, h, w, n, R_{e}, F_{r}$ (Lamouroux and Souchon, 2002; Souchon and Capra, 2004); the fact that model outputs do not indicate the cause of the reduced habitat suitability (Maddock, 1999); the requirement complex and expensive model-input data (Lamouroux and Souchon, 2002); and, that the model outputs do not capture habitat patterns, only probabilistic habitat preferences (Wheaton et. al., 2004a).

\subsection{River morphology}

Both brown and rainbow trout redd construction typically occur in riffles of gravel bed streams, where the relatively high velocities and clean/coarse substrate that characterize these morphological features occur (Knighton, 1998; Hartley, 1999Table 2.2). The formative processes that dictate channel morphology provide the physical link between salmonids and their spawning grounds, a connection that is implicitly neglected when assessing lotic habitats using local-scale metrics (Imhof et al., 1996). Imhof et al. [1996] add that this neglect is a result of the spatial scale many fishies biologists choose to analyze the system; in the literature reviewed, redd-site selection has been widely investigated based on these finer-scales (Table 2.1). Trush [1989] acknowledged that "channel morphology determines the location, abundance, quality, and availability of spawning gravels"; hence, the local-scale conditions that provide optimal spawning grounds are dictated by both reach-scale and sub-watershed-scale processes (Imhof et al., 1996).

The mechanisms contributing to riffle-pool particle sorting can be explained 

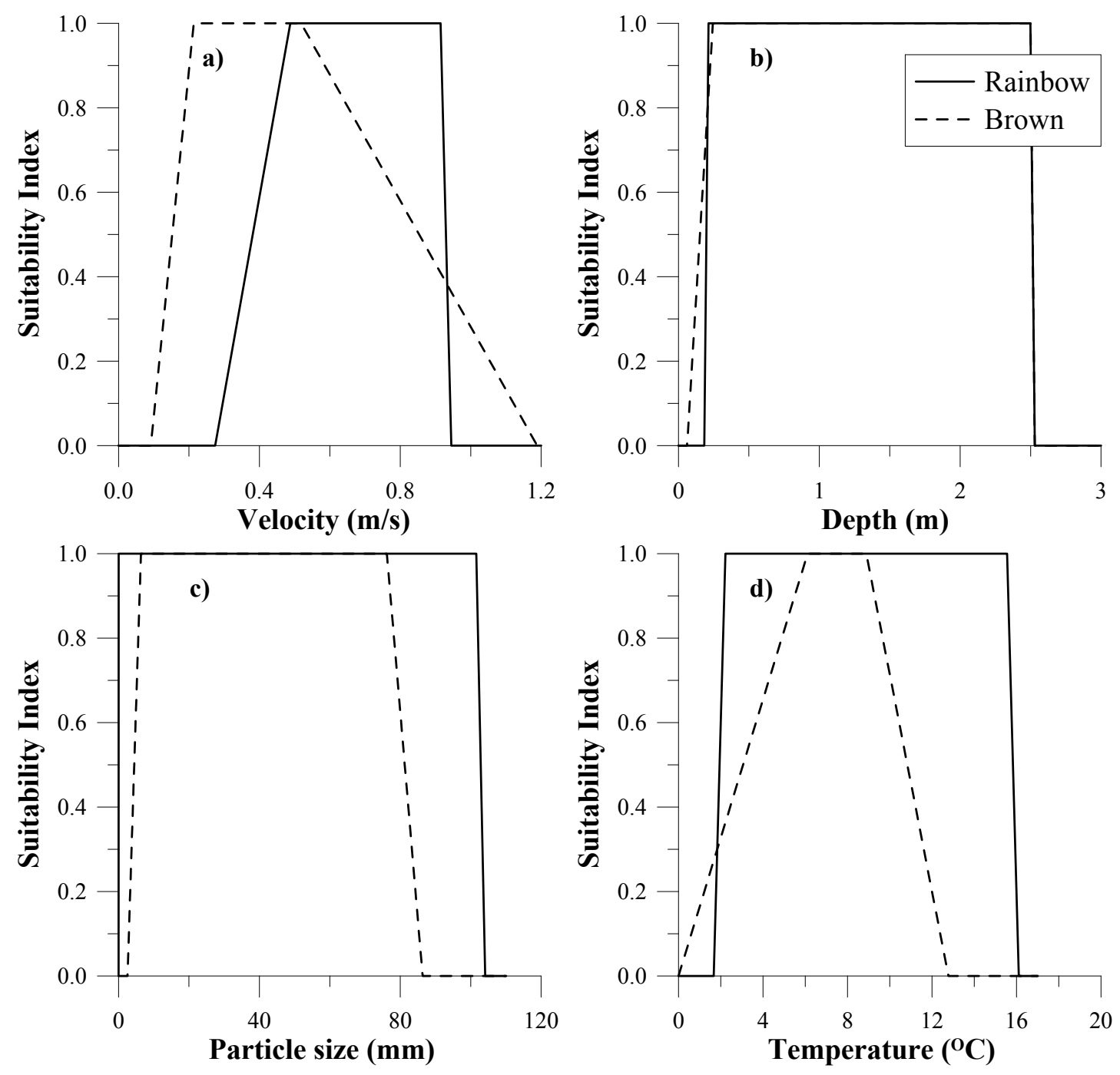

Figure 2.4: Suitability factors for spawning brown trout and rainbow trout, modified form Raleigh et al. [1984,1986]. a) velocity, b) depth, c) substrate size, and d) water temperature. 
Table 2.2: Discharge-specific physical differences between riffles and pools along a typical riffle-pool channel (modified from Hartley, 1999).

\begin{tabular}{|c|c|c|}
\hline & Riffles & Pools \\
\hline Substrate character & Coarse, reduced fines & $\begin{array}{l}\text { Higher composition of } \\
\text { mud, silt and clay }\end{array}$ \\
\hline Local elevation & Topographically high & Topographically low \\
\hline Flow type (Froude number) & $\begin{array}{l}\text { Supercritical or transi- } \\
\text { tional } F_{r}>0.4\end{array}$ & $\begin{array}{l}\text { Subcritical } F_{r}<0.18 \\
(\text { citing Jowett, 1993) }\end{array}$ \\
\hline Local bed slope $\left(S_{0}\right)$ & Greater than $S_{0}$ & Less than $S_{0}$ \\
\hline Velocity to depth ratio & High & Low \\
\hline
\end{tabular}

in theory by "the law of least time rate of energy expenditure" (Yang, 1971) or by velocity reversal (Keller, 1971; Lisle, 1979), where relatively little increase in bed shear occurs with increasing discharge, in stark contrast to the situation in pools (Knighton, 1998). Leopold et al. [1964] indentified that natural channels maintain an average riffle-pool spacing of 5-7 bankfull widths $\left(w_{b f}\right)$, and a meander wavelength $\Lambda \approx 10 w_{b f}$. Leopold and Maddock [1953] formulated cross-sectional hydraulic geometry to define other dimensional relationships common to steady uniform flow among natural channels:

$$
Q=w h U
$$

where $Q$ is total discharge $\left[L^{3} T^{-1}\right], w$ is channel width $[L]$, and

$$
w=a Q^{b} ; \quad h=c Q^{f} ; \quad U=k Q^{m} .
$$

Whereby, to preserve continuity

$$
a c k=1 ; \quad b+f+m=1 .
$$

Knighton [1998] adds

$$
S_{f}=g Q^{z}
$$

Julien [2002] proposed an alternative form of hydraulic geometry involving total discharge, sediment size, and bed shear as primary independent variables that define the dependent variables $w, h, U$, and $S_{0}$, based upon Lane's [1955] river continuum. Knighton [1998] shows how hydraulic geometry can help contrast riffles from pools 
at varying discharge rates, using the exponents from Equation 2.13:

$$
\begin{aligned}
f_{\text {riffle }} & >f_{\text {pool }} ; \\
m_{\text {riffle }} & <m_{\text {pool }} ; \\
z_{\text {riffle }}<0 & , \quad z_{\text {pool }}>0 .
\end{aligned}
$$

\subsubsection{Channel roughness}

The kinetic energy of the channel's flowing water is dissipated by means of friction at the sediment-water interface. Water flowing along a channel can be represented by a free body, sliding down an inclined plain with a given friction. The driving force of the river's flow is the tangential component of gravity parallel to the streambed, while the resistance is a function of the shear stress acting over a given area of streambed, otherwise referred to as bed roughness (Leopold et al., 1964). Reachscale bed roughness can be approximated by Manning's Equation (Equation 2.7Leopold and Maddock, 1953). With respect to discharge, the Manning's equation can alternatively be represented by

$$
Q=\frac{\theta}{n} A R^{\frac{2}{3}} S_{f}^{\frac{1}{2}}
$$

where $A=$ cross-sectional flow area $\left[L^{2}\right]$.

The above equation demonstrates that the capacity for a channel to convey water is a function of bed roughness. Manning's coefficient of roughness $(n)$, however, is difficult to quantify. Reach-scale roughness $n$ approximations are given in the works of Morisawa [1968], Arcement and Schneider [1989], and Newbury and Gaboury [1993]. Julien [1998] listed three alternative in which $n$ is related to sediment size, taken in meters:

$$
\begin{aligned}
& n=0.064 \sqrt[6]{d_{50}} \\
& n=0.046 \sqrt[6]{d_{75}} \\
& n=0.038 \sqrt[6]{d_{90}}
\end{aligned}
$$

where $d_{50,75,90}=$ the particle diameter at which $50 \%, 75 \%, 90 \%$ of the sediment sample is finer, respectively.

Friction slope $\left(S_{f}\right)$ is defined as the loss in total energy per length of channel, $x$ (Julien, 2002):

$$
S_{f} \cong S_{0}-\frac{\partial h}{\partial x}-\frac{U}{g} \frac{\partial U}{\partial x}-\frac{1}{g} \frac{\partial U}{\partial t}
$$

where $t=$ time $[T]$. 
For steady uniform flow, $\frac{\partial U}{\partial x}=\frac{\partial U}{\partial t}=\frac{\partial h}{\partial x} \approx 0$; therefore

$$
S_{f} \approx S_{0}
$$

Thus, all of the energy grade line (of slope $S_{f}$ ), the hydraulic grade line (the slope of the water surface, $S_{w}$ ), and the stream bed (of slope $S_{0}$ ) are assumed to be parallel, and the flow within the channel has achieved a state of minimal energy expenditure. Water flowing over a rough stream bed results in shear stresses at the sediment-water interface. Bed shear stress per unit area of streambed ${ }^{1}$ is given by

$$
\tau_{0}=\gamma R S_{f}
$$

where $\quad \tau_{0}=$ bed shear stress $\left[M L^{-1} T^{-2}\right]$.

\subsubsection{Sediment transport}

All natural channels are dynamic systems attempting to achieve maximum sediment transport with minimal energy expenditure (Yang and Song, 1979; Knighton, 1998). Lane [1955] proposed the qualitative relationship

$$
Q_{s} d \propto Q S_{0}
$$

where $Q_{s}=$ total sediment discharge $\left[M T^{-1}\right]$;

$S_{0}=$ bed slope $[L / L]$.

The above equation states that equilibrium conditions exist between sediment conditions on the left-hand side and hydraulic conditions on the right-hand side. For a low-gradient, gravel bed stream, the attainment of Lane's [1955] relationship (2.26) results in the typical meandering and riffle-pool undulations (Knighton, 1998; Julien, 2002) through a variety of mechanisms dictated by interrelated channel variables: width $(w)$, depth $(h)$, velocity $(U)$, bed slope $\left(S_{0}\right)$, sediment load $\left(Q_{s}\right)$, sediment size $(d)$, bed roughness $(n)$ (or equivalent sand roughness $\left(k_{s}\right)$-Nikuradse, 1933), and discharge $(Q)$ (Leopold et al., 1964), amongst others. At the watershedscale, the hydraulic variables $(w, h, U, Q)$ are dictated by the local hydrology, and the sediment characteristics $\left(Q_{s}, d, n\right.$, and $\left.k_{s}\right)$ are dictated by the local geology and land use (Leopold et al., 1964). Bed slope, however, is adjusted through changes in meander geometry/sinuosity, where an increase in sinuosity $(\Omega)$ results in a decrease in channel slope (Leopold et al., 1964).

$$
\Omega=\frac{\text { channel length }}{\text { valley length }}
$$

Further, the meanders of natural channels induce a helical secondary flow that adds a radial shear stress $\left(\tau_{r}-\left[M L^{-1} T^{-2}\right]\right)$ to the sediment surface. Julien [2002]

\footnotetext{
${ }^{1}$ Bed shear in relation to redd site selection has been investigated by Cooper [1965] and Kondolf et al. [1993], with no success.
} 
describes secondary flow as generated through changes in downstream channel orientation, where water surface streamlines approaching a bend are deflected toward the inner bank along the streambed, generating radial shear $\left(\tau_{r}\right)$ and directing particles toward the inner bank to form the point bar. Julien [2002] adds that the centrifugal forces generating secondary flow are countered by the radial shear stress abating the circular motion, further dissipating energy. The sharper the bends, the stronger the secondary currents (Knighton, 1998; Julien, 2002). It is due to these secondary flows that significant pooling occurs at bends rather than at the shallow inflection points, namely riffles, along low-gradient streams (Julien, 2002).

A general measure of sediment transport is stream power (Yang, 1972). Bagnold [1980] defined stream power as the "mean rate of kinetic energy supply and dissipation along a stream channel," where

$$
\omega=\gamma Q S_{f}
$$

and $\omega=$ stream power $\left[M L T^{-3}\right]$.

Unit stream power per unit area of stream bed ${ }^{2}$ is defined as

$$
\omega_{a}=U \tau_{0}=\frac{\gamma Q S_{f}}{w}
$$

where $\omega_{a}=$ stream power per unit area of stream bed $\left[M T^{-3}\right]$, having the S.I. units of $\mathrm{W} / \mathrm{m}^{2}$ (Leopold et al, 1964).

An alternative form is known as stream power per unit weight, where $\omega_{w}=U S_{0}$. Yang [1972] defined $\omega_{w}$ as the "time rate of potential energy expenditure per unit weight of water." In all cases, stream power is postulated as being constant along the length of a stable channel (Leopold et al., 1964) and should achieve its minimum once a channel stabilizes (Keller, 1998). Only part of this rate of doing work is available to transport bed load (Leopold et al., 1964), and there are many other approaches used to assess the movement of bed load, based on the analysis of shear stress, energy slope, discharge, velocity, and bed form (Yang, 1996).

The shape and size of an active channel is dictated by periods of high bedload movement, and typically, this movement occurs at discharges approaching and exceeding bankfull (Emmett and Wolman, 2001; Rosgen, 2006). Bankfull discharge $\left(Q_{b f}\right)$ is defined by Leopold et al. [1964] as "the flow that fills the channel to the top of its banks at a point where the water begins to overflow onto a floodplain." Bankfull discharge for a natural channel with minimal anthropological land use typically recurs at 1.05-2.20 years (Leopold et al., 1964; Annable, 1996).

Incipient motion leading to fluvial entrainment and thus sediment transport is dependent on a balance between hydrodynamic forces, lift and $\operatorname{drag}\left(F_{L} \sim\right.$

\footnotetext{
${ }^{2}$ Unit stream power per unit area of stream bed as it relates to redd-site selection has been investigated by Kondolf et al. [1993]. Sediment yield has been investigated by Lisle and Lewis [1992]; both investigations were unsuccessful.
} 
$F_{D} \sim \tau_{0} d^{2}$ ), and gravitational forces with respect to the particle's submerged weight $\left(F_{S}=F_{W}-F_{B} \sim\left(\gamma_{s}-\gamma\right) d^{3}\right)$ as demonstrated in Figure 2.5. The ratio of hydrodynamic to gravitational forces is the dimensionless Shields entrainment function ( $\tau_{*}$-Shields, 1936), where

$$
\tau_{*}=\frac{\tau_{0}}{\left(\gamma_{s}-\gamma\right) d}
$$

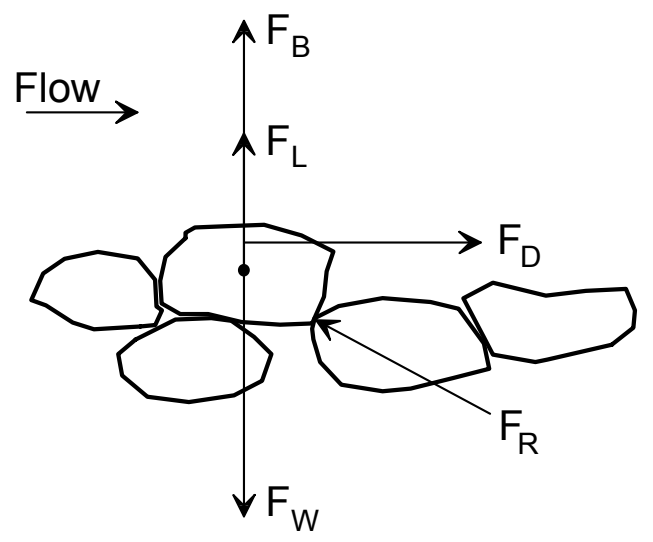

Figure 2.5: Force diagram under steady uniform flow (modified from Julien, 1998).

The Shields diagram, which relates the Shields entrainment function against the grain shear Reynolds number $\left(R_{e *}\right)$, shows that for a critical dimensionless shear stress $\left(\tau_{* c}\right)$, particles of size $d$ will become entrained. However, for non-cohesive sediment in turbulent flow, when $R_{e *}>70$, which is typical of natural gravel-bed channels (Julien, 2002), $\tau_{* c}$ remains constant, ranging between 0.045 (Julien, 1998; Knighton, 1998; Sturm, 2001) and 0.047 (Julien, 2002), or $\tau_{* c} \approx 0.06 \tan \phi$, when $R_{e *}>50$ (Julien, 1998), where $\phi$ is the sediment angle of repose. $\left(\phi \approx 38^{\circ}\right.$ for medium-coarse gravel, depending on the sphericity of the particles - Julien, 2002.) Therefore in hydraulically rough turbulent conditions, the Shields entrainment function becomes independent of particle size (Julien, 1998) and viscous effects (Vanoni, 2006). Once entrained, the conveyance of sediment depends on the energy of flow (i.e., stream power).

$$
\begin{aligned}
R_{e *} & =\frac{u_{*} d_{65}}{\nu} ; \\
u_{*} & =\sqrt{\frac{\tau_{0}}{\rho}},
\end{aligned}
$$

where $R_{e *}=$ grain shear Reynolds number $[-]$;

$$
u_{*}=\text { shear velocity }\left[L T^{-1}\right] \text {. }
$$

With $\tau_{* c}$ remaining constant, Julien [1998] provides a plot that reduces Equation 2.30 to critical bed shear $\left(\tau_{c}\right)$ as a function of median grain size (measured in meters), where

$$
\tau_{c}=C d_{50}
$$


and the coefficient $C \approx 790 \mathrm{~Pa} / \mathrm{m}$, yet ranges $630<C<1260 \mathrm{~Pa} / \mathrm{m}$. The initiation of particle movement may be related to stream velocity, provided that the depth of flow is small, where $h<1 \mathrm{~m}$ (Vanoni, 2006). Keulegan [1938] defined critical velocity as

$$
\begin{aligned}
U_{c} & =5.75 \sqrt{\tau_{* c}(G-1) g d_{50}} \log \frac{12.2 h}{k_{s}} \\
& =5.75 u_{* c} \log \frac{12.2 h}{k_{s}} .
\end{aligned}
$$

where $\quad U_{c}=$ critical depth-averaged velocity $\left[L T^{-1}\right]$;

$$
u_{* c}=\text { critical shear velocity }\left[L T^{-1}\right] \text {. }
$$

An alternative form is intended by Julien [2002] for riprap design, where

$$
U_{c}=1.2 \sqrt{2(G-1) g d}
$$

Julien [2002] warns, however, that the above critical velocity relationships are valid only when $h \approx 5 d$ can be satisfied. For conditions where $h>10 d$, the shear stress method (Equation 2.30) is recommended (Julien, 2002; Vanoni, 2006).

\subsubsection{Boundary-layer flow}

Shear can also be determined through the logarithmic turbulent velocity profile, otherwise known as boundary-layer flow the of the "Law of the Wall" (von Kármán, 1930; Prandtl, 1932). The Law of the Wall is defined as

$$
\frac{d u}{d z}=\frac{u_{*}}{\kappa \cdot z}
$$

where $\kappa=$ the von Kármán constant $\approx 0.4[-]$.

Integrating Equation 2.37 yields

$$
\frac{\bar{u}(z)}{u_{*}}=\frac{1}{\kappa} \ln \left(\frac{z}{z_{0}}\right),
$$

where $\bar{u}(z)=$ is the time-averaged velocity at height $z$ above the stream bed $\left[L T^{-1}\right]$;

$z_{0} \quad=$ roughness length $[L]$, where $\bar{u}\left(z_{0}\right)=0$.

Integrating Equation 2.38 over flow depth $h$ and assuming $h \gg z_{0}$, yields

$$
\frac{U}{u_{*}}=\frac{1}{\kappa} \ln \left(\frac{h}{e z_{0}}\right) .
$$


Originally based on the work of Nikuradse [1933], roughness length has been approximated by an equivalent sand grain roughness ( $k_{s}$-Monin and Yaglom, 1971). For open channel flow, Keulegan [1938], White [1940], and Einstein [1950] recommend

$$
k_{s} \approx 33 z_{0} \text {. }
$$

Substituting Equation 2.40 into 2.39 produces the Einstein-Keulegan form, assuming $h \gg k_{s}=d_{65} \gg \delta_{\nu}$. For hydraulically rough turbulent flow, where $R_{e *}>70$, the correction factor $x_{e}=1$ (Einstein, 1950). The Einstein-Keulegan equation is the origin of Equation 2.35:

$$
\begin{gathered}
\frac{U}{u_{*}}=5.75 \log \left(\frac{12.2 R x_{e}}{k_{s}}\right) ; \\
\delta_{\nu}=\frac{11.6 \nu}{u_{*}},
\end{gathered}
$$

where $x_{e}=$ correction factor, $x_{e}=1$ when $k_{s} / \delta_{\nu}>5$ and $k_{s}=d_{65}$

$[-]$

$\delta_{\nu} \quad=$ viscous sublayer thickness $[L]$.

Estimation of surface roughness $k_{s}$ varies among sources: $k_{s}=d_{50}$ (Strickler, $1923) ; k_{s}=d_{65}$ (Einstein, 1950); $k_{s}=3.1 d_{90}, k_{s}=3.5 d_{84}, k_{s}=5.2 d_{65}$, and $k_{s}=6.8 d_{50}\left(\right.$ Bray, 1980); $k_{s}=4.66 d_{84}$ (ranging between $k_{s}=1.5-7.0 d_{84}$ (Clifford et al., 1992); $k_{s}=1.4 d_{84}, k_{s}=3.2 d_{84}$, or $k_{s}=2.4 d_{84}$ (Sturm, 2001). However, $k_{s}=3.5 d_{84}$ by Hey [1979] is most commonly used both in geomorphology (Church et al., 1990; Sturm, 2001) and in lotic ecology (Rempel et al., 2000).

The formative processes that dictate reach-scale channel morphology depend on many watershed-scale characteristics. As illustrated by Lane's [1955] balance (Equation 2.26), channel stability is dependent on a dynamic balance between water and sediment inputs, which, in turn, are dependent on local hydrology, past and present land use, past and present climate, hillslope characteristics, vegetation type, size of watershed, sediment characteristics, and upstream channel processes (Rosgen, 2006). Further, Rosgen [2006] adds that channel equilibrium can never be truly achieved since the watershed is exposed to many dynamic processes. Channel hydraulics depend on surface roughness (Equation 2.7), and it is apparent from Equations 2.20 to 2.22 that a relationship exists between surface roughness and sediment character. Accelerated sediment yield due to changes at the watershedscale often results in channel instability (Rosgen, 2006). Thus, watershed-scale characteristics have as much of a significant impact on salmonid spawning grounds as local-scale characteristics do (Imhof et al., 1996). 


\section{Chapter 3}

\section{Methodology}

Whiteman's Creek, located near Paris, Ontario, Canada (Figure 3.1) was selected to investigate the hydrodynamic characteristics of sites selected by spawning fish. Research by Hartley [1999] identifies that the selected reach supports diverse environmental niches. Preliminary reconnaissance of the study reach (Figure 3.2) in the spring of 2006 identified 19 redds along an approximate $1.9 \mathrm{~km}$ reach.

Whiteman's creek is characterized as a low gradient, flood plain dominated, gravel bed river with the following characteristics (Hartley, 1999): stream gradient $\left(S_{0}=0.27 \%\right)$, sinuosity $(\Omega=1.6)$, effective catchment area $\left(A_{d}=383 \mathrm{~km}^{2}\right)$, bankfull discharge $\left(Q_{b f}=42 \mathrm{~m}^{3} / \mathrm{s}\right)$, average bankfull width $\left(w_{b f}=23.2 \mathrm{~m}\right)$, average bankfull depth $\left(h_{b f}=1.1 \mathrm{~m}\right)$, and average grain size distributions on riffles of $d_{16}=11.8 \mathrm{~mm}, d_{50}=42.8 \mathrm{~mm}, d_{84}=90.9 \mathrm{~mm}$, and for the entire reach of $d_{16}=8.1 \mathrm{~mm}, d_{50}=33.4 \mathrm{~mm}, d_{84}=72.8 \mathrm{~mm}$.

The chosen species were the spring-spawning rainbow trout and the fall-spawning brown trout, hereinafter referred to as simply salmonids. Both species prefer to construct redds near the crests of gravel bed riffles, away from either bank (Burner, 1951; Hayes, 1987; Lisle, 1989). Redd identification was undertaken within a week of spawning, when strong visual contrast could be identified in bed material prior to periphytic regrowth (Witzel and MacCrimmon, 1983a,b; Grost et al., 1990; Beard and Carline, 1991; Schmetterling, 2000; J. Imhof, pers. comm.). Riffles identified with redds were selected for detailed hydrodynamic analysis.

\subsection{Site survey}

Field work commenced in April 2006 when spring freshet flows had receded (Figure 3.3). Table 3.1 provides a chronology of field activities. Field reconnaissance was undertaken to identify the locations of established and attempted redds along the study reach. Redd locations were identified with a Trimble Geo XT ${ }^{\circledR}$ sub-metre accurate GPS. Based upon the equipment used, field work was limited to safe wadeable flow depths and velocities. Flow conditions exceeding $12 \mathrm{~m}^{3} / \mathrm{s}$ (corresponding 


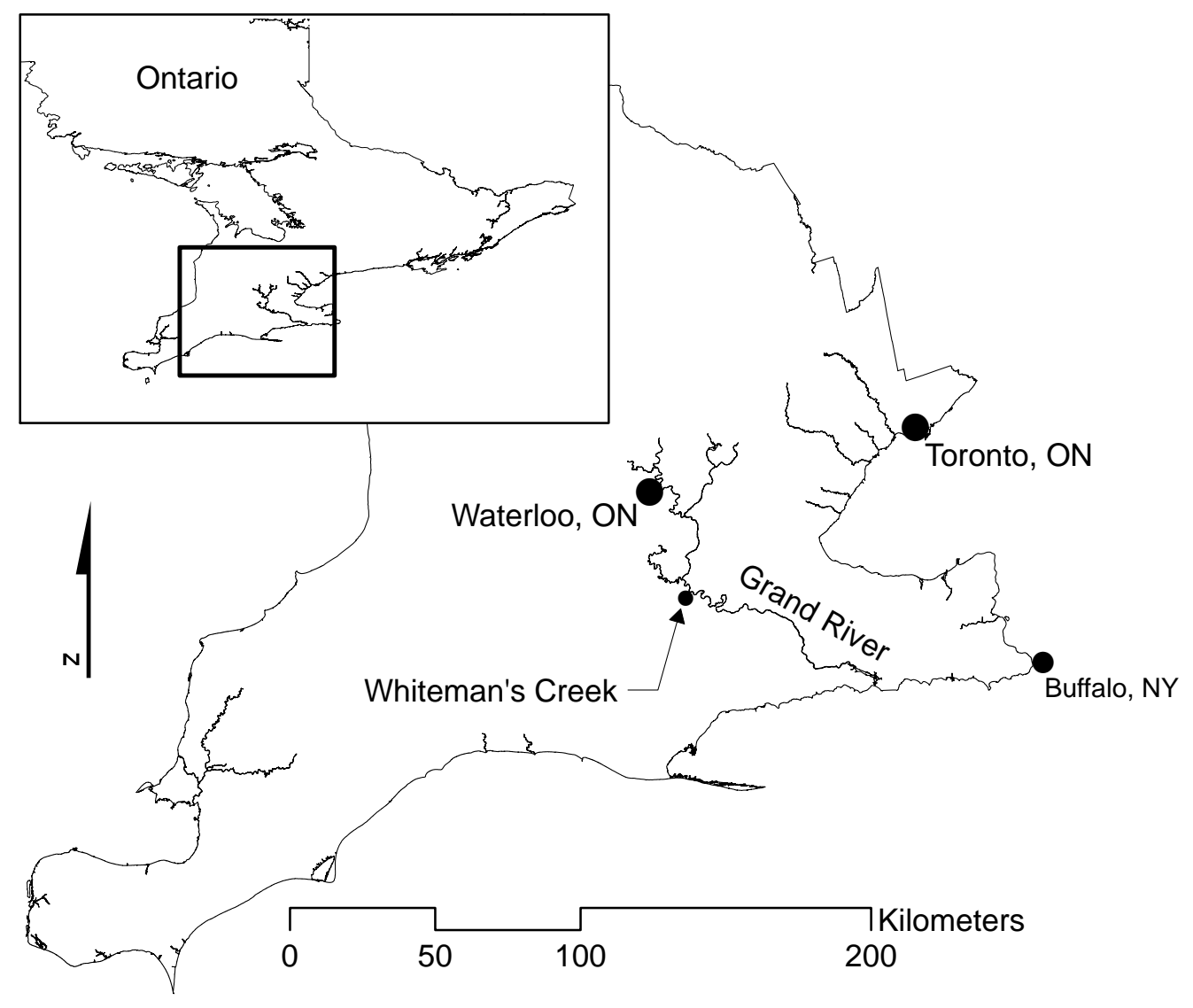

Figure 3.1: Site location of Whiteman's Creek, Southern Ontario, Canada.

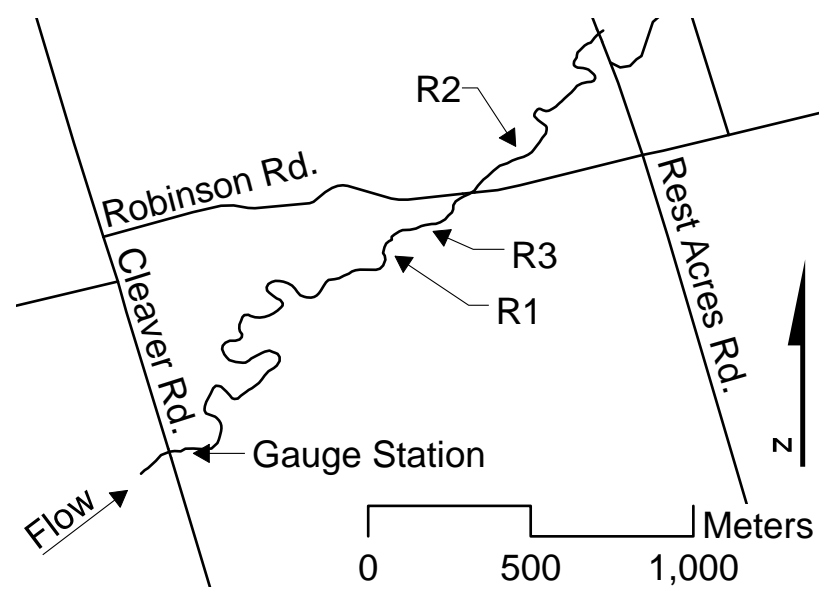

Figure 3.2: Site map of Whiteman's Creek. R1,R2,R3 - Study riffles 1,2,3 respectively. WSC gauge station: Whiteman's creek near Mount. Vernon (02GB008). 


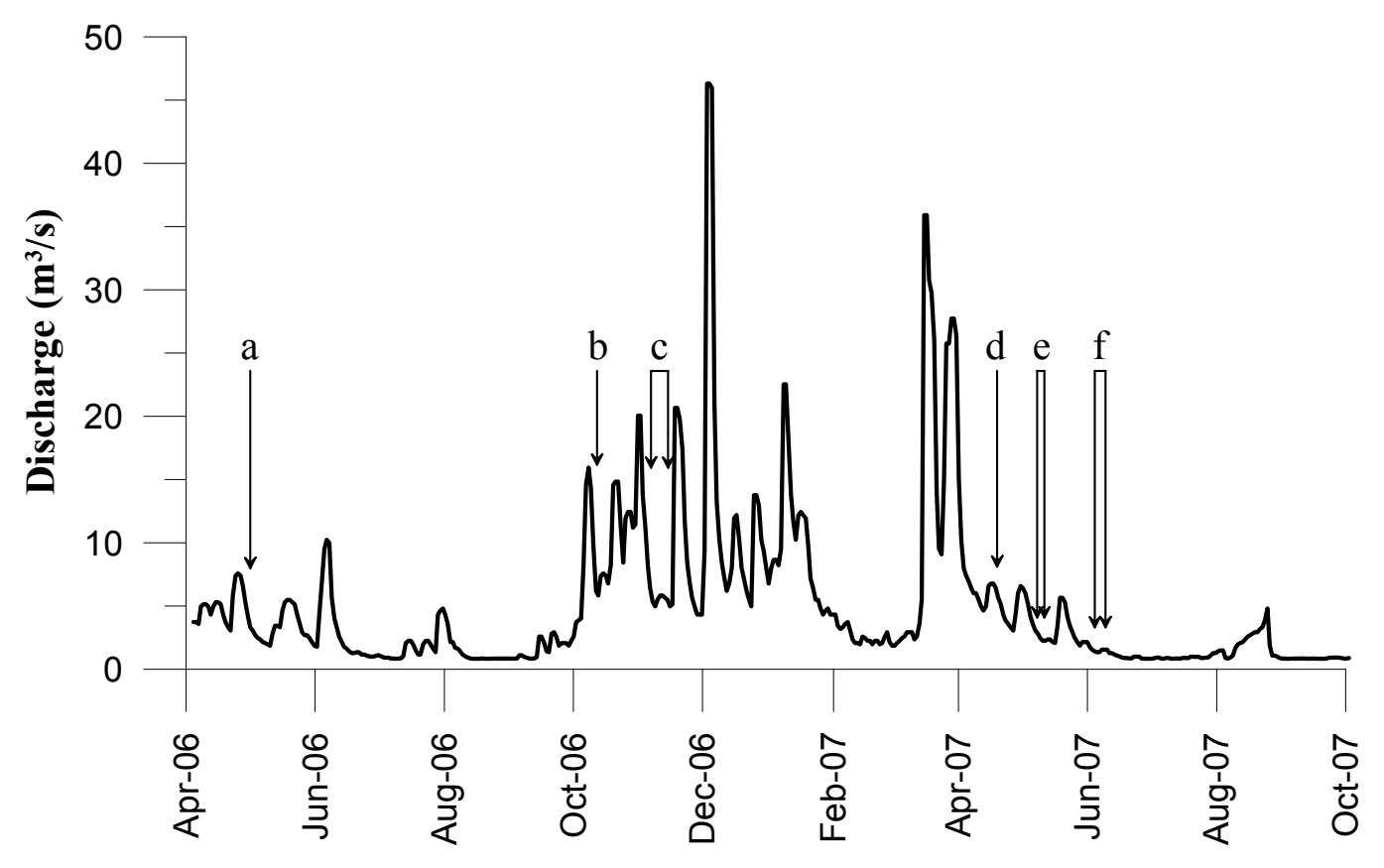

Figure 3.3: Discharge record of Whiteman's Creek. Fieldwork chronology as described in Table 3.1 .

Table 3.1: Chronology of Whiteman's creek field work.
a) April 19, 2006
Rainbow trout were active; spawning season had begun. Redds discovered were located using GPS.
b) October 13 No sign to date of brown trout activity. By October 20, ve- locities along riffles were in excess of $1.4 \mathrm{~m} / \mathrm{s}$ (equivalent to a discharge of $10 \mathrm{~m}^{3} / \mathrm{s}$ ). There was limited visibility within the river, thus spawning could not be identified.
c) November 6-15 PCADP data were acquired over brown trout redds. Notice that this period was a short window between two high flow events. $\bar{Q}=5.55 \mathrm{~m}^{3} / \mathrm{s}$.
d) $\quad$ May 1, 2007
Commencement of rainbow trout spawning was observed at multiple locations; although only a limited number of redds were ultimately constructed.
e) May 9-11 PCADP data were acquired over rainbow trout redds. Similar to measurements over brown trout redds, measurements were acquired within a short window between high flow events. $\bar{Q}=$ $2.33 \mathrm{~m}^{3} / \mathrm{s}$.
f) May 29-June $6 \quad 2.7 \mathrm{~km}$ longitudinal, cross-sectional and planform total station site survey was completed.


to near-bank velocities in excess of $1.4 \mathrm{~m} / \mathrm{s}$ ) were considered dangerous and were avoided.

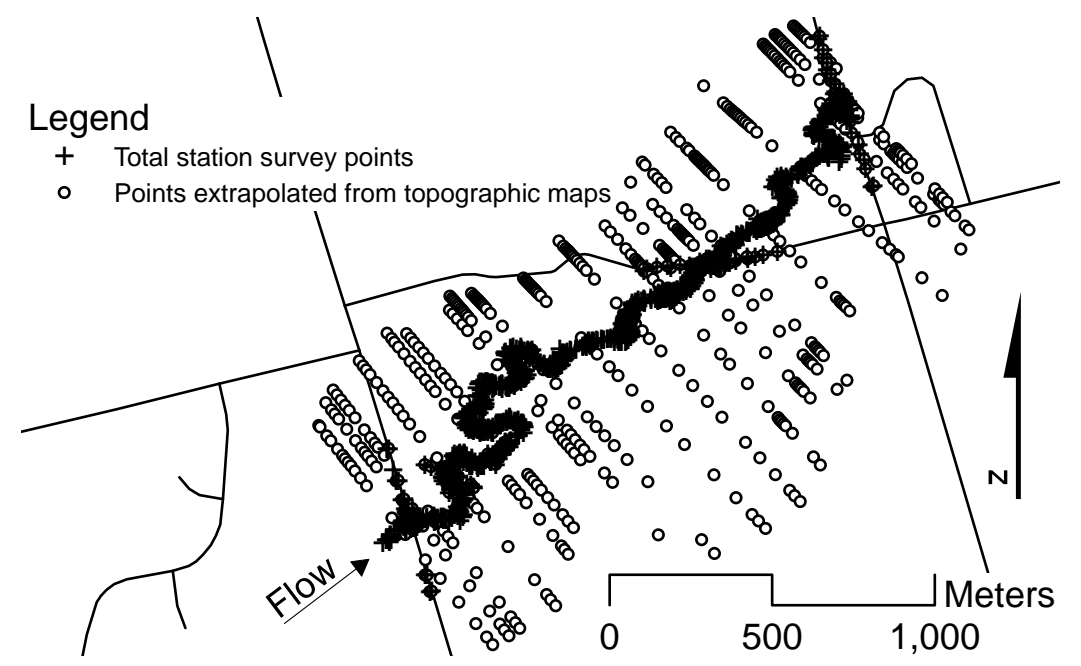

Figure 3.4: Total station field survey and complementary topographic cross-sections of the Whiteman's creek study reach.

A series of cross-sections (Figure 3.4) and a longitudinal profile (Figure 3.5) were surveyed along the study reach using methods consistent with Annable [1996] using a Set 5 E Sokkia ${ }^{\circledR}$ total station, data logger and single-optic prism pole. Total station surveys were geo-referenced to North American Datum (NAD) 1983 UTM Zone $17 \mathrm{~N}$ coordinates acquired with a Trimble Geo XT ${ }^{\circledR}$ GPS unit at the starting and ending control benchmarks of each survey. Elevations were referenced to the Ontario Ministry of Transportation (MTO) benchmark 828082.

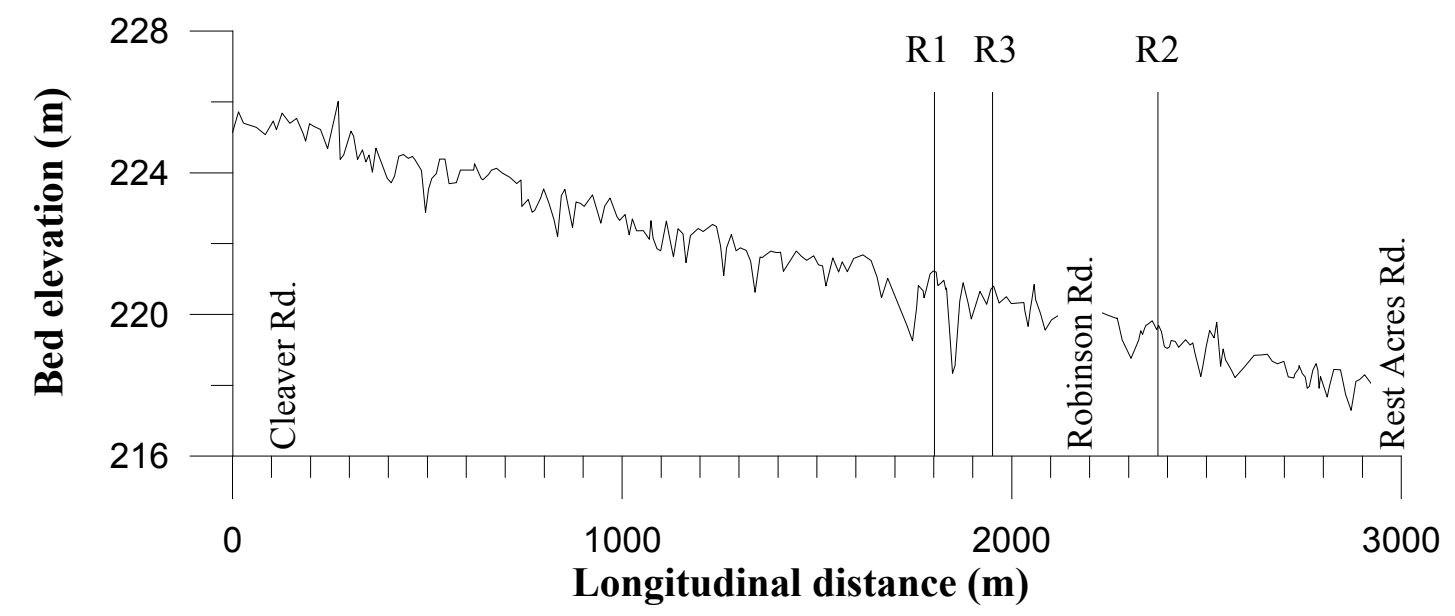

Figure 3.5: Longitudinal profile of Whiteman's creek. R1,R2,R3-High-resolution velocity measurement study riffles $1,2,3$ respectively.

Thalweg and centreline measurements were obtained along the length of the study reach at approximately every bankfull channel width. The maximum inverts 
of pools, notable changes in channel slope, and the tops and bottoms of riffles, and headcuts were also surveyed, consistent with the methods outlined by Annable [1996]. The lengths of riffles and runs, and the inter-riffle/inter-pool spacing were determined from the longitudinal profile. Slopes were determined from the average elevation of three survey points obtained at the tops and bottoms of each morphological feature.

Cross-sections define the geometric boundary of the natural channel perpendicular to flow along the channel and adjacent floodplain. Cross-sections were defined and measured perpendicular to the channel within the upper third of each riffle and extended out into the flood plains in sufficient detail to define cross-sections for undertaking hydraulic analysis using Hydrologic Engineering Center's River Analysis System (HEC-RAS ${ }^{\circledR}$ 4.0) for flood conditions. At each cross-section, characteristics such as top and bottom of banks, bankfull stage, and the channel thalweg were defined, in addition to all notable breaks in slope and terraces identified in the field. Ideally, the extent of each cross-section was surveyed from, at minimum, the top of the valley walls to the channel thalweg. In cases where it was not possible to extend the cross-section to the top of the valley walls, due to line of sight limitations, the extents of the cross-sections along the floodplain were extrapolated using topographic maps at a scale of 1:10000 and Digital Elevation Models (DEMs), once the field surveys were geo-referenced.

\subsection{Sediment sampling}

Sediment samples were collected using the barrel sampling technique (Bunte and Apt, 2001). Three samples were collected around each measured redd (immediately upstream, left and right of the each redd, Figure 3.6). Other samples were collected at the top of each study riffle, and at locations known to be occupied by redds during previous spawning seasons. Grain size analysis was conducted in the laboratory on each sediment sample using dry sieving methods at $0.5 \Phi$ intervals (Friedman and Sanders, 1978) for particles smaller than $32 \mathrm{~mm}$, where

$$
\Phi=-\log _{2} d
$$

Particles greater than $32 \mathrm{~mm}$ were measured and massed individually in the field and segregated into $0.5 \Phi$ intervals. Both field and dry sieve data of each sample were combined and the $d_{5}, d_{16}, d_{25}, d_{50}, d_{75}, d_{84}, d_{95}$ percentiles were determined.

The particle distribution of fluvial sediment tend to approximate a normal distribution when expressed in $\Phi$-intervals (Bunte and Abt, 2001). The graphic arithmetic sorting coefficient is thus used to classify the degree of sorting (Folk and Ward, 1957). The sorting coefficient provided by Inman (1952) is expressed as begin

$$
S_{I}=\left|\frac{\Phi_{84}-\Phi_{16}}{2}\right|
$$




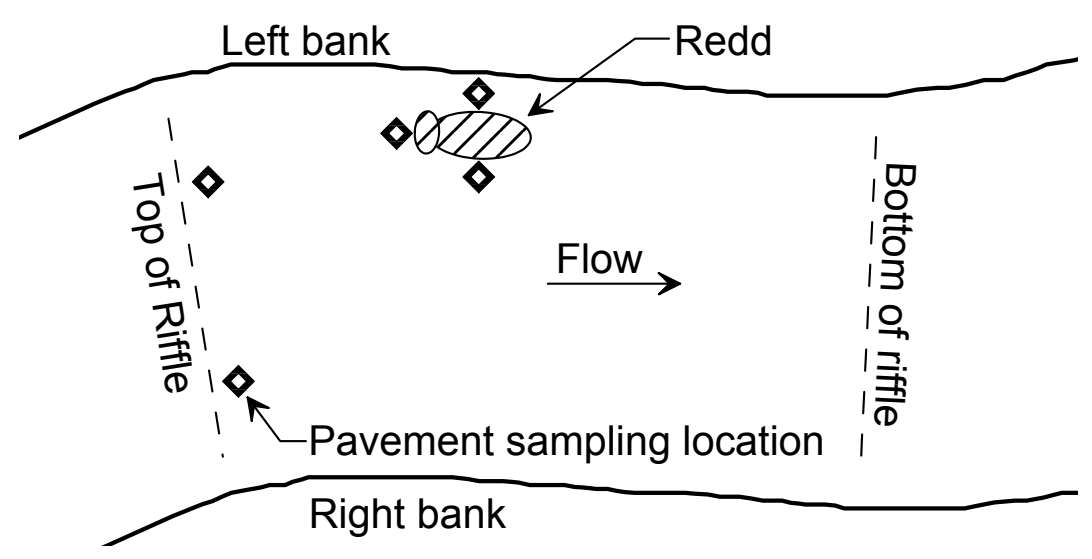

Figure 3.6: Planimetric sediment sampling locations proximal to redds and at the tops of riffles.

and Folk and Ward [1957] provided the alternative form:

$$
S_{F W}=\frac{\Phi_{84}-\Phi_{16}}{4}+\frac{\Phi_{95}-\Phi_{5}}{6.6}
$$

where $\quad S_{I}=$ the Inman [1952] sorting coefficient [-];

$S_{F W}=$ the Folk and Ward [1957] sorting coefficient [-];

$\Phi_{n} \quad=$ the $n^{\text {th }}$ percentile $\Phi$-size $[\Phi$ units].

Sediment analysis outlined by Friedman and Sanders [1978] was used to characterize the bed material samples rather than the fredle index employed by many fishery biologists (Witzel and MacCrimmon, 1983a; Sowden and Power, 1985; Beard and Carline, 1991; Kondolf et al., 1993; Bernier-Bourgault and Magnan, 2002). The fredle index $\left(f_{i}\right)$, expressed as the ratio of the substrate's particle size to its degree of sorting, was developed by Lotspeich and Everest [1981] to analyze the degree of fine reduction during redd construction. Kondolf [2000] noted, however, that the geometric mean in the fredle index should be replaced by the standard form used in engineering and sedimentological practise, where $d_{g}=d_{50}$, since the numerator's role in the fredle index is to assess the central tendency of the sample's distribution. Kondolf [2000] also pointed out that the sorting index ignores all particles smaller than $d_{25}$; therefore, fines most detrimental to embryonic survival, i.e., $d<1 \mathrm{~mm}$ (Phillips et al., 1975; Witzel and MacCrimmon 1983b; Sowden and Power, 1985; Kondolf et al., 1993; Kondolf, 2000), may be overlooked. Further, the fredle index does not account for the sediment's degree of compaction or armouring. Kondolf [2000] suggested that the conventional Inman [1952] sorting index $\left(s_{g}\right)$ should be applied, where

$$
s_{g}=\sqrt{\frac{d_{84}}{d_{16}}} .
$$

The particle gradations were employed to classify the bed material size distribution of each morphological feature, to estimate roughness parameters $\left(n, k_{s}\right)$ 
required for hydraulic analysis, and to calculate critical shear and critical velocity thresholds. The sedimentological definitions of grain size moments were used to provide consistency in comparing various hydraulic, fluid mechanics, and biological linkages.

\subsubsection{Critical particle size}

With the use of a conservative constant value of 0.03 for the critical dimensionless Shield's entrainment function (Equation 2.30), a value said to be "the minimum dimensionless critical shear stress determined for rough beds under fully turbulent flow" (Lacey and Miller, 2004 - quoting Yalin and Karahan, 1979), and known bed shear, the largest particle size that will become entrained has the average diameter of

$$
d_{c}=C \tau_{0},
$$

where $\quad d_{c}=$ the critical particle diameter $[L]$;

$C=0.0021 \mathrm{~m}^{2} \mathrm{~s}^{2} / \mathrm{kg}$.

\subsection{Acoustic Doppler Profiler}

A SonTek ${ }^{\mathrm{TM}}$ Pulse Coherent Acoustic Doppler Profiler $(P C A D P$ ) was employed to measure three-dimensional velocities on a high resolution discretized spatial scale. Measurements were taken over the same locations at different times of the year to obtain results under varying discharge and flow depth conditions.

The PCADP is a downward looking velocity profiler capable of obtaining velocity readings at $1.6 \mathrm{~cm}$ vertical increments ranging between $5 \mathrm{~cm}$ below the PCADP to the channel bed. Three transducers emit sound pulses, otherwise known as beams, $15^{\circ}$ from the PCADP's principal axis (Figure 3.7). Each transducer measures the phase difference between a returning pair of beams that have been reflected off waterborne particles. The combination of the three beam pairs results in a three-dimensional velocity profile which can be transformed into Cartesian coordinates of $u_{x}, u_{y}, u_{z}$. The operation of the PCADP implicitly assumes that there is homogeneity of flow between the three beams at every given depth, where the distance between each beam is roughly $40 \%$ depth of measurement. The relative error associated with the PCADP is dependent on depth of measurement, velocity of water, temperature of water and length of averaging interval. A $30 \mathrm{~s}$ averaging interval over a depth of $1 \mathrm{~m}$ produces 104 beam pairs per sample, resulting in a maximum error of $\pm 0.03 \mathrm{~cm} / \mathrm{s}$. 


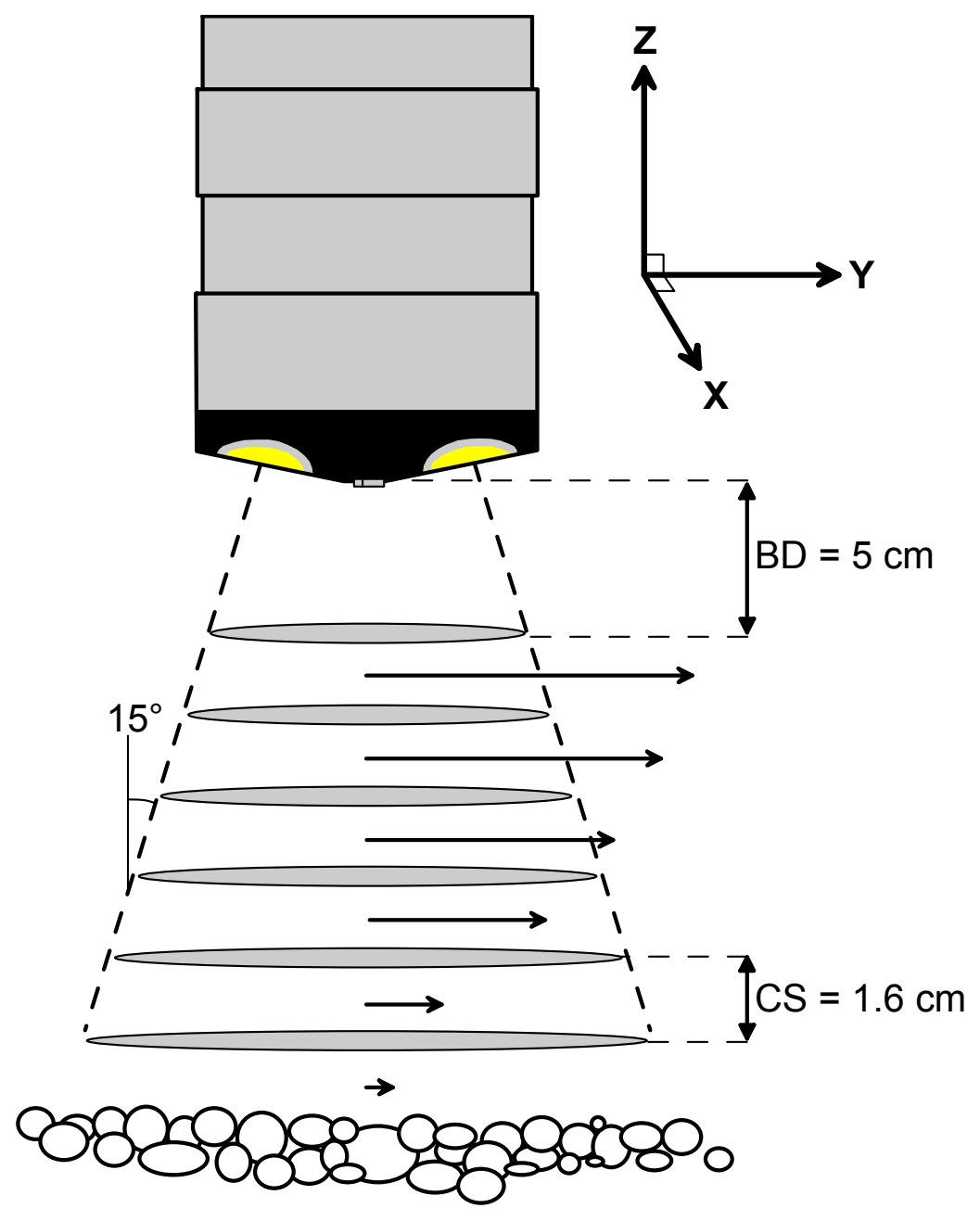

Figure 3.7: PCADP velocity measurements application for sampling depth and resulting velocity profile. CS-cell size; BD-Úblanking distance. 


\subsection{The PCADP Cage}

Application of the PCADP requires a fixed position to accurately obtain velocity profiles. The PCADP is commonly employed in laboratory flumes or at fixed locations in rivers and along shorelines to sample velocity changes over extended periods of time. For the intended application, two-dimensional spatial data was of particular interest at short sampling periods where the discharge could be assumed to be relatively constant.

The PCADP was integrated into a table-like apparatus (referred to as the Cage-Figure 3.8) to obtain velocity profiles on a planimetric spatial discretization of $\Delta x=\Delta y \geq 20 \mathrm{~cm}$. The cage was developed such that the discrete position of each velocity profile could be obtained and geo-referenced to UTM coordinates. At each corner of the cage, four total station prism mounts were integrated into the design such that the cage could be picked up and moved to a different location and geo-referenced to the same spatial coordinate system, as illustrated in Figure 3.9 (by use of a Sokkia ${ }^{\circledR}$ Set $5 \mathrm{E}$ total station). Site survey and cage locations were referenced to geo-referenced standard iron bars $(S I B s)$ that were installed along the banks of the stream to provide permanent survey benchmarks for subsequent surveys.

a)

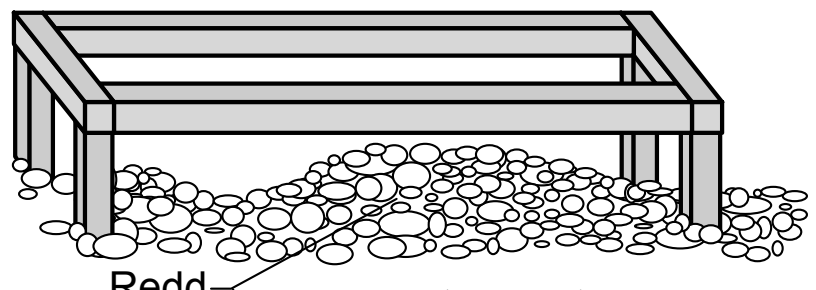

b)

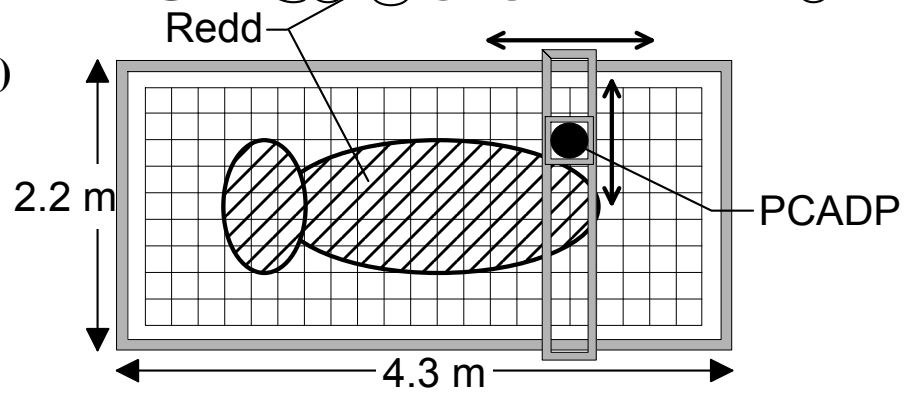

Figure 3.8: a) Oblique and b) plan-view of the cage.

Outriggers were also integrated into the cage design to minimize wake turbulence induced by the upstream legs (Figure 3.10). Given that the longest dimension of the cage is oriented in the direction of flow, the wake formed by the outrigger legs will not enter the sampling area. Typically, when measuring riffle velocities, which ranged between $0.6 \mathrm{~m} / \mathrm{s}$ and $1.0 \mathrm{~m} / \mathrm{s}$, the ratio of the distance downstream to the wake's lateral displacement was approximately 4:1. 


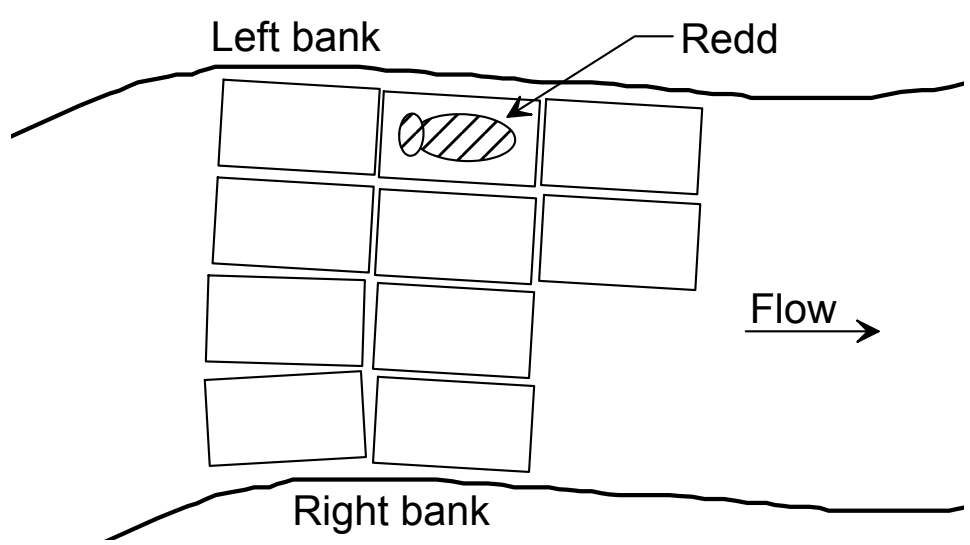

Figure 3.9: Plan view of a riffle reach where multiple cage readings have been undertaken. The shaded area represents a field identified redd.

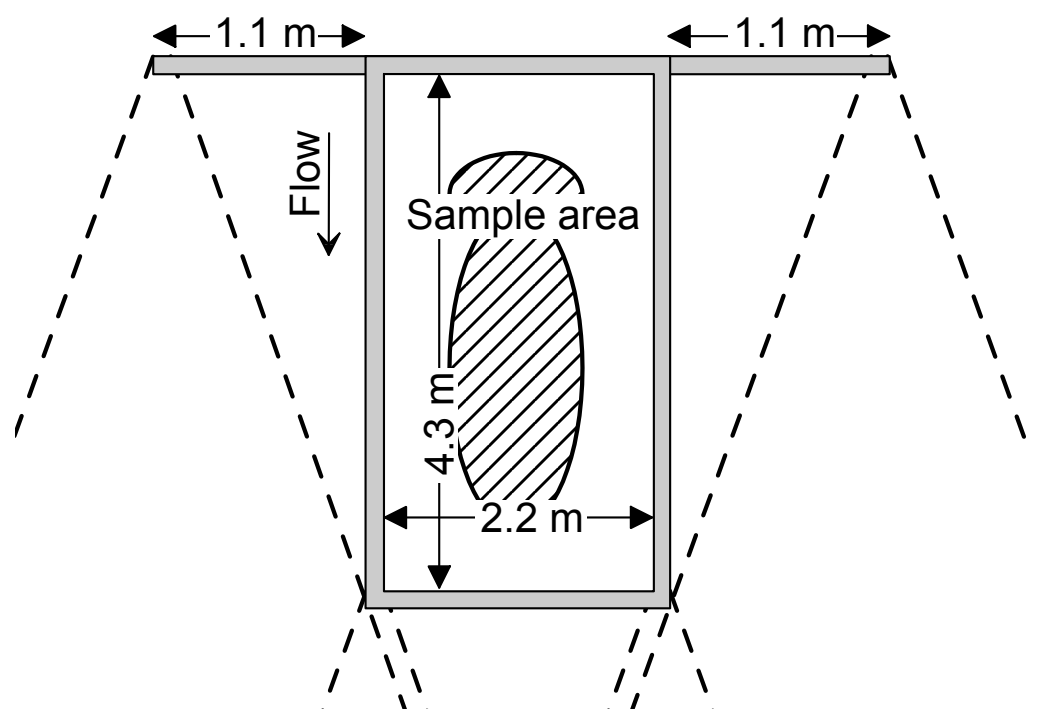

Figure 3.10: The wake caused by outriggers will not interfere with the measurement area. 


\subsection{Post processing and analysis}

\subsubsection{Boundary-layer profiles and local shear}

The PCADP's intended design was to collect velocity profiles from a stationary location over a long duration (days to months). Consequently, post processing software to organize PCADP measurements at multiple spatial locations over shorter periods of time were not commercially available. Discrete field velocity profiles were conducted using 30 second averaging intervals $(A I)$ followed by a 5 second pause required for the repositioning of the PCADP to each cage grid position (i.e., a 35 second profile interval-PRI). Based upon the geo-referenced cage locations, the geo-referenced coordinates of each velocity profile and the elevation of each discrete velocity was assigned. The magnitude of each discrete velocity was numerically computed as a function of the natural logarithm of the height above the streambed, consistent with the Law of the Wall (Equation 2.38). Integrating Equation 2.37, this time without applying the boundary condition $u\left(z_{0}\right)=0$ yields

$$
\bar{u}(z)=a+b \ln z .
$$

From linear regression, the shear velocity was determined by

$$
u_{*}=\kappa b,
$$

and roughness length by

$$
z_{0}=e^{-a / b} .
$$

Linearly regressed profiles with a minimum coefficient of determination of $r^{2}=$ 0.90, with respect to Equation 3.6, were considered, all others were rejected. Further, profiles with less than five velocity measurements per profile, i.e., profiles with less than 5 sample cells, were also eliminated. With the exception of the riffle 1 rainbow trout study (which was conducted in low-flow conditions), $92 \%$ of the remaining 2356 profiles measured exceeded five sample cells, at a cell size of $1.6 \mathrm{~cm}$ (Figure 3.11).

For profiles with $r^{2}<0.90$, up to three outliers were removed until the minimum coefficient of determination $\left(r^{2}=0.90\right)$ was reached. The majority of outliers were found amongst the bottom two cells, a distance of $3.2 \mathrm{~cm}$ above the sediment-water interface, presumably due to turbulence caused by the roughness elements. Under these criteria, $69.1 \%$ of the 2683 total profiles fit the logarithmic trend according to Equation 3.6 and were accepted for further hydrodynamic analysis (Table 3.2).

The majority of boundary-layer profiles exhibited strong uniformity with respect to the law of the wall. By comparing equation 2.38 to 2.39 it can be demonstrated that $U=\bar{u}\left(e^{-1} h\right)$, which is known as the "0.6 depth method," where $e^{-1} h=0.37 h$, 


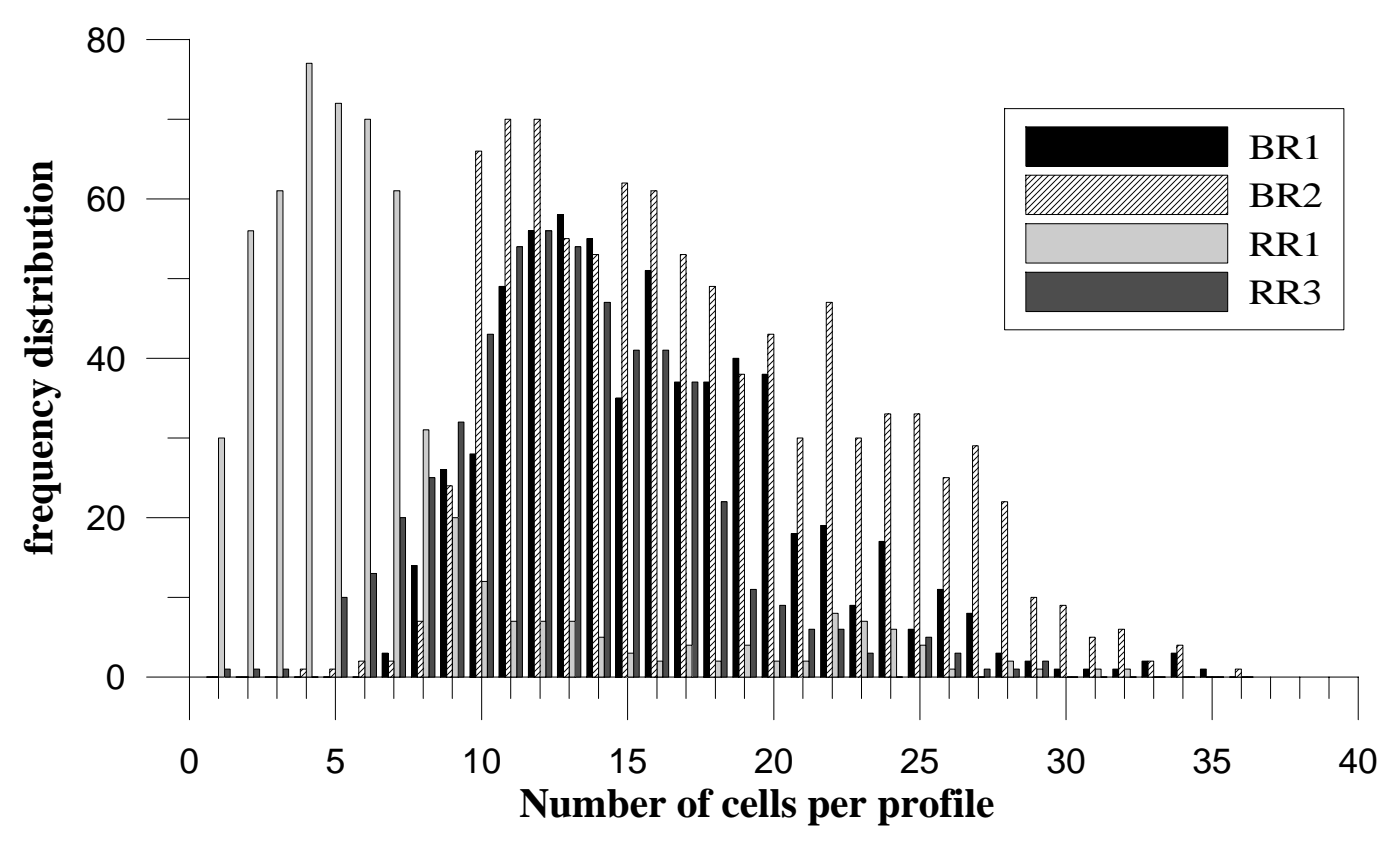

Figure 3.11: Frequency distribution of PCADP profile lengths per study riffle.

(that is, $37 \%$ of the depth from the stream bed). Applying this equality to equation 3.6 yields

$$
U=a+b \frac{h}{e} .
$$

Equation 3.9 provides a method of testing the accuracy of the collected data by plotting mean velocity of every profile against mean profile velocity as a function of profile height, slope, and intercept. Regardless of the location and time of measurement, the mean velocity of 1853 profiles relates to Equation 3.9 with near-perfect agreement, having a coefficient of determination, $r^{2}>0.999$ (Figure 3.12a).

Alternatively, shear velocity calculated from 1853 logarithmic profile slopes (Equation 3.7) shows similar agreement when plotted against shear velocity calculated using Equation 2.39 with known mean profile velocity, profile height, and roughness length, having an $r^{2}=0.998$ (Figure 3.12b). In addition, recall that in deriving Equation 2.39, the assumption $z_{0} \ll h$ was made for simplification. On average, roughness length at all study sites was $\bar{z}_{0} \approx 2.5 \mathrm{~mm}$, yet it did reach a maximum of $z_{0, \max }=50 \mathrm{~mm}$ on several occasions. Thus, high roughness lengths, which correspond to high shear, did achieve lengths where the assumption $z_{0} \ll h$ can no longer hold. Neglecting this assumption the complete form of the Law of the Wall is thus given by

$$
\frac{U}{u_{*}}=\frac{1}{\kappa} \cdot \frac{h-z_{0}}{z_{0}+h \ln \frac{h}{e z_{0}}} .
$$


Table 3.2: Success of acquired profiles from each study riffle at varying minimum acceptable coefficients of determination when fit to Equation 3.6. BR1 signifies Brown trout, Riffle 1.

\begin{tabular}{ccccccc}
\hline$r^{2}$ & BR1 & BR2 & RR1 & RR3 & Total & Percent \\
& & & & & & \\
\hline $50 \%$ & 548 & 919 & 337 & 526 & 2330 & $86.8 \%$ \\
$60 \%$ & 516 & 911 & 329 & 521 & 2277 & $84.9 \%$ \\
$75 \%$ & 447 & 894 & 326 & 510 & 2177 & $81.1 \%$ \\
$90 \%$ & 283 & 794 & 307 & 469 & 1853 & $69.1 \%$ \\
$95 \%$ & 167 & 587 & 275 & 394 & 1423 & $53.0 \%$ \\
$99 \%$ & 19 & 72 & 154 & 119 & 364 & $13.6 \%$ \\
Total & 629 & 943 & 566 & 545 & 2683 & $100.0 \%$ \\
& & & & & & \\
\hline
\end{tabular}
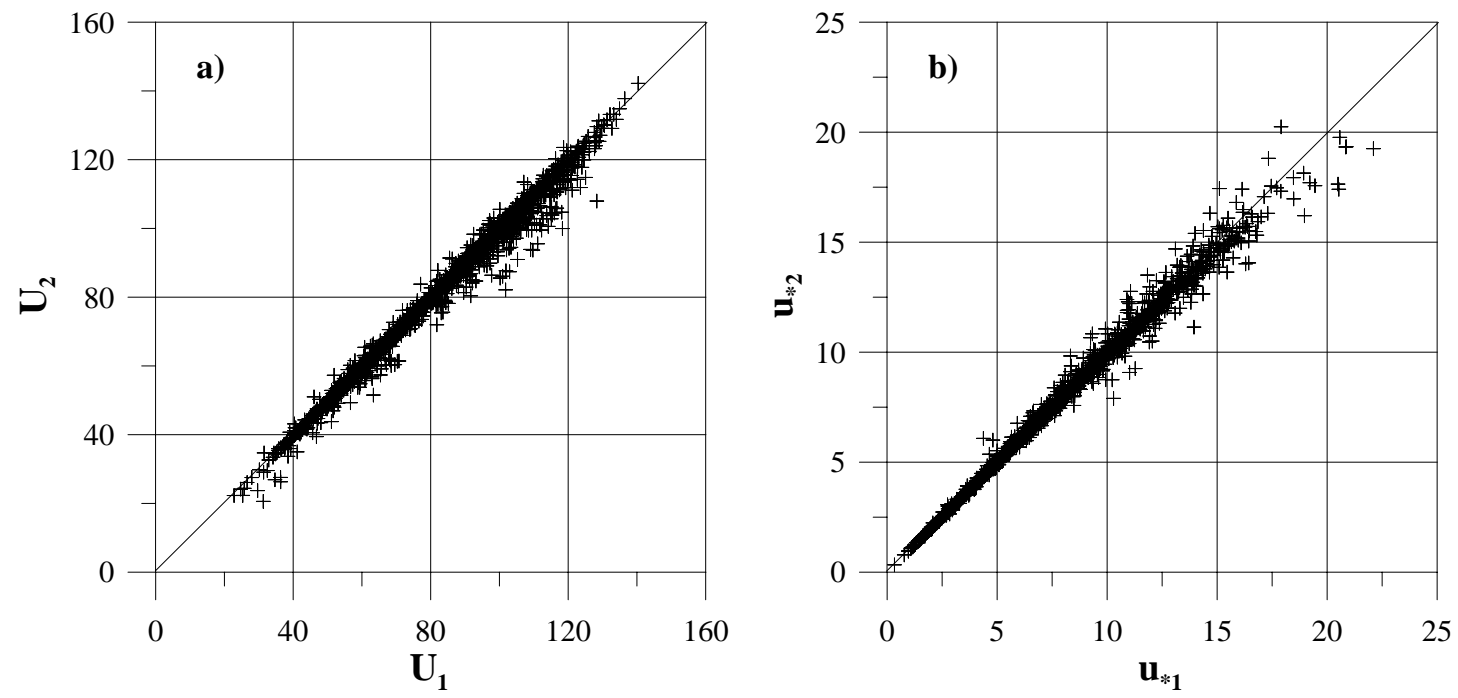

Figure 3.12: a) Empirically-measured mean profile velocity, $U_{1}$, agrees with $U_{2}-$ mean profile velocity as a function of profile height, intercept, and slope (Equation 3.6). $r^{2}>0.999$. b) Shear velocity as a function of velocity profile slopes, where $u_{* 1}=\kappa b$, agrees with $u_{* 2}$ calculated from Equation 3.10 with known mean profile velocity, depth, and roughness length. $r^{2}=0.998 . n=1853$. Units: $\mathrm{cm} / \mathrm{s}$. 


\subsubsection{Local roughness}

Local bed shear determined by boundary-layer profile analysis will be used to approximate local roughness. Roughness can be defined by Darcy-Weisbach friction factor:

$$
f=\frac{8 \tau_{0}}{\rho U^{2}},
$$

where $f=$ Darcy-Weisbach friction factor $[-]$.

Substitution of Equation 2.32 into 3.11 yields

$$
\frac{U}{u_{*}}=\sqrt{\frac{8}{f}},
$$

Which is also equivalent to the right hand side of the integrated form of the Law of the Wall (Equation 2.39). The Darcy-Weisbach friction factor can be related to the Manning's roughness coefficient by

$$
\sqrt{\frac{8 g}{f}}=\frac{h^{1 / 6}}{n} ;
$$

Therefore, by introducing a local Manning's roughness coefficient $\left(n_{l}\right)$, combining Equations 3.12 and 3.13, and using locally-measured shear velocity, local roughness can then be approximated by

$$
n_{l}=\frac{u_{*} h^{1 / 6}}{\sqrt{g} U},
$$

where $n_{l}=$ Local Manning's roughness $\left[T L^{-1 / 3}\right]$.

\subsubsection{Turbulent kinetic energy}

Methods used to define physical habitat are mostly two-dimensional (planform) metrics which implicitly assumes depth-wise homogeneity, in the similar sense that hydraulic equations such as the Manning's equation and DuBoys bed shear equation implicitly assumes planform homogeneity (i.e., uniform flow). To illustrate any depth-wise trends, a modification of turbulent kinetic energy was developed. An alternative to the Reynolds number as a measure of turbulence, mean turbulent kinetic energy per unit mass is used to assess the consistency of time-averaged velocity measurements (Moody and Smith, 2004; Stone et al., 2006; Smith and 
Brannon, 2007):

$$
\bar{e}=\frac{1}{2}\left(\sigma_{x}^{2}+\sigma_{y}^{2}+\sigma_{z}^{2}\right)
$$

where $\quad \bar{e} \quad=$ turbulent kinetic energy per unit mass $\left[L^{2} T^{-2}\right]$;

$$
\begin{aligned}
\sigma_{x}^{2}, \sigma_{y}^{2}, \sigma_{z}^{2} & =\text { variance of velocity in the } x-, y-, z \text {-direction, re- } \\
& \text { spectively }\left[L^{2} T^{-2}\right] .
\end{aligned}
$$

The data collected are thirty-second time-averaged velocities. If the above form is modified where the variance is calculated from the collection of individual threedimensional velocities that constitute a single velocity profile, a water column with a reduced influence from secondary flows will be indicated by a reduced overall turbulent kinetic energy along the depth of the velocity profile. Analyzing the above equation along the profile length yields the mean turbulent kinetic energy per unit area of streambed:

$$
\bar{e}_{a}=\frac{1}{2} \rho h\left(\sigma_{x}^{2}+\sigma_{y}^{2}+\sigma_{z}^{2}\right)
$$

where $\quad \bar{e}_{a} \quad=$ turbulent kinetic energy per unit area $\left[M T^{-2}\right]$, having the S.I. units of $\mathrm{J} / \mathrm{m}^{2}$;

$\sigma_{x}^{2}, \sigma_{y}^{2}, \sigma_{z}^{2}=$ depth-averaged variance of velocities in the $x-, y-$, $z$-direction, respectively, which constitute one complete profile $\left[L^{2} T^{-2}\right]$. 


\section{Chapter 4}

\section{Results}

Brown trout redds were located at five separate riffles within the study reach, however, only two of these riffles were chosen for detailed hydrodynamic analysis, namely riffle 1 (R1) and riffle 2 (R2), (Figure 4.1). The choice of these two study riffles was, to some extent, based on access, however, and most importantly, they were chosen mainly because they demonstrated high spawning activity, with multiple redds present with further evidence of superimposition and abandoned/incomplete redd attempts. Riffles 1 and 2 were also active with rainbow trout spawning in the spring of that year, identified during the preliminary site selection process. Hence, based on the observed spawning activity, these two riffles were deemed preferred spawning grounds.

Discharge at Whiteman's creek during the spring of 2007 was unseasonably low, and this was reflected in the lack of rainbow trout redd production when compared to the 2006 season. Rainbow trout redds could only be identified along two riffles (R1 and R3-Figure 4.1), and thus were chosen for PCADP analysis.

Cage-PCADP analysis was performed in a patch-work process, gathering velocity data above and proximal to constructed redds (Figure 4.2). Vertical velocity profile measurements were evenly distributed typically at a spacing of $60 \mathrm{~cm}$, with the exception of profiles measured above redds, where the sample density was increased to a $20 \mathrm{~cm}$ grid spacing. The choice of spacing was to maximize the overall sampling area within the least amount of time, in order to minimize effects caused by changes in discharge.

\subsection{Sediment analysis}

Sediment analysis at Whiteman's creek is summarized in Table 4.1. All sediment samples were poorly sorted, based on the samples' gradation standard deviation $\left(s_{g}=\sqrt{d_{84} / d_{16}}\right)$, and the samples' graphic arithmetic coefficient (Folk and Ward, 1957; Bunte and Abt, 2001). The sorting coefficients calculated using the twopercentile Inman [1952] method (Equation 3.2), or the four-percentile Folk and 


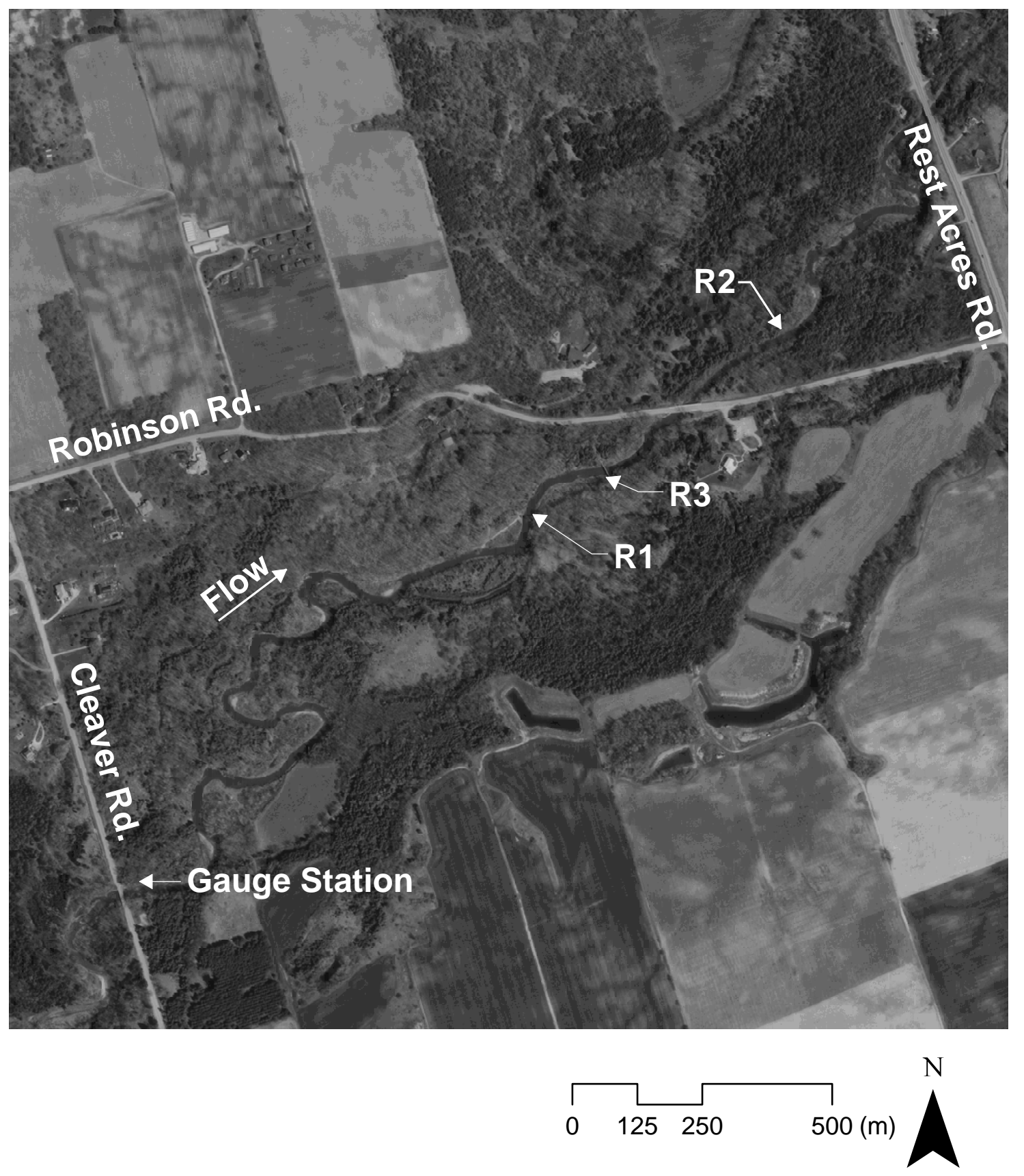

Figure 4.1: Aerial photograph of study site outlining locations of the detailed PCADP hydrodynamic analysis. R1 refers to Riffle $\mathbf{1 .}$ 


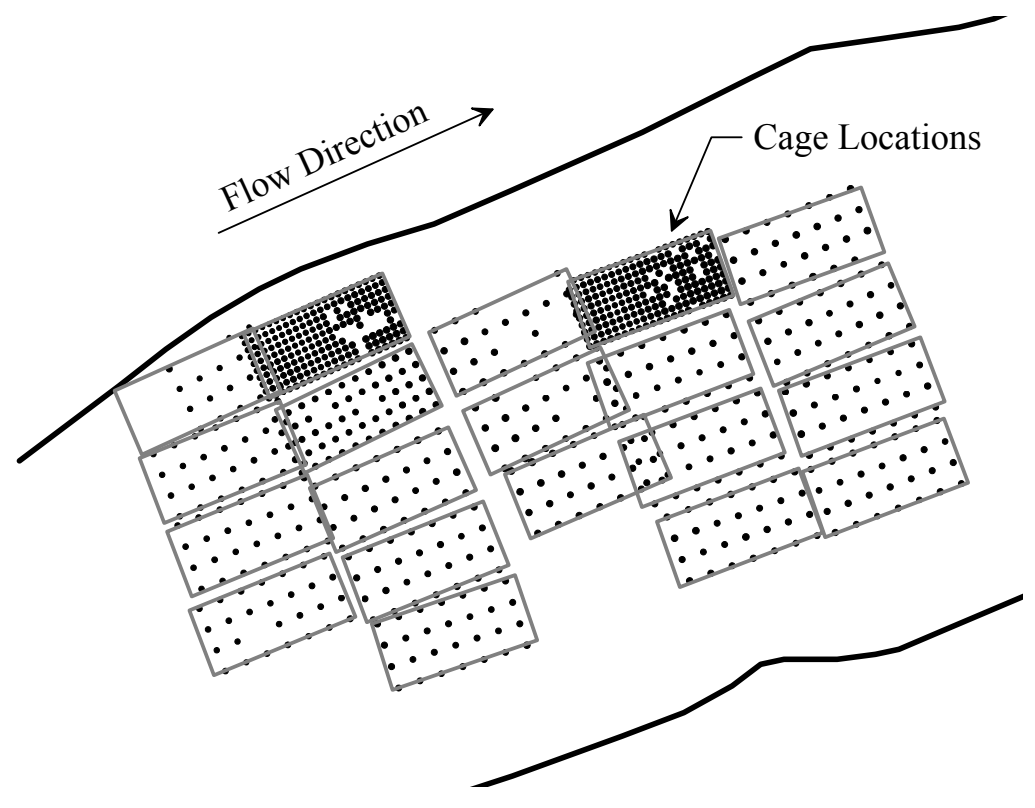

Figure 4.2: PCADP sample distribution at riffle 2 during the brown trout spawning season (fall 2006). In a patch-work fashion, 20 cage were placed along the study riffle, totalling 943 vertical velocity profiles, each consisting of 39 sample cells, for a grand total of 36,777 point velocity measurements.

Ward [1957] method (Equation 3.3) yielded the exact results (Table 4.1). Approximately $5 \%$ by mass of all samples consisted of fines less than $1 \mathrm{~mm}$ in diameter, the size deemed detrimental to fry development (Kondolf et al., 1993). When comparing the particle distribution of near-redd samples and top-of-riffle samples, little difference in particle distribution is apparent. Particle size distribution was also consistent with the sediment distribution reported by Hartley [1999] for Whiteman's Creek riffle substrate.

Table 4.1: Aggregate sediment analysis of three riffle sites at Whiteman's creek. B-2006 brown trout survey; $\mathbf{R}-2007$ rainbow trout survey. All units are mm.

$$
\begin{array}{lllllllllll}
d_{5} & d_{16} & d_{25} & d_{50} & d_{65} & d_{75} & d_{84} & d_{90} & d_{95} & s_{g} & S_{I}
\end{array}
$$

The three methods of approximating Manning's $n$ listed in Julien [1998] (Equations 2.20-2.22) were inconsistent. Equation $2.22\left(n=0.038 \sqrt[6]{d_{90}}\right)$, however, best 
approximated local Manning's roughness determined through boundary-layer analysis $\left(n_{l}-\$ 3.5 .2\right)$ listed in Table 4.3. Although the values of the local Manning's roughness coefficient are low with respect to Morisawa [1968], Newbury and Gaboury [1993], and Julien [1998], they did match observed conditions when applied to HECRAS $^{\circledR}$ analysis at low-flow conditions (§4.4).

Equivalent sand roughness height $\left(k_{s}\right)$-back-calculated from the mean measured roughness length, where $k_{s}=33 z_{0}$, was inconsistent with the conventional Hey [1979] or Bray [1980] approximations. Bray [1980] introduced the coefficient

$$
C_{n}=\frac{k_{s}}{d_{n}},
$$

where $\quad d_{n}=$ grain size at which $n \%$ of the sample is finer $[L]$;

$C_{n}=$ Bray coefficient [-].

In fact, $k_{s}$ most resembled Einstein's [1950] original approximation of $k_{s}=$ $d_{65}$, yet more closely resembled $k_{s}=d_{84}$ (Table 4.2). Both Hey [1979] and Bray [1980] defined the relationship between $k_{s}$ and $d_{n}$ based on the Einstein-Keulegan equation, where the DuBoys bed shear equation was used to estimate shear velocity, where $u_{*}=\sqrt{g R S}$. Hey [1979] and Bray [1980] empirical data was collected from UK gravel-bed streams and Alberta gravel-bed streams, respectively; hence, since their approximation agreed with one-another, $k_{s}=3.5 d_{84}$ was made convention. Based on the data collected for this study, the use of any of Bray's [1980] coefficients would have greatly overestimated bed shear; hence these relationships may be region specific and are to be used in channels of similar dimension within basins of similar hydrologic characteristics.

Table 4.2: Bray coefficients calculated by Equation 4.1 using six pavement samples and 143 velocity profiles measured within a $1 \mathrm{~m}$ buffer surrounding two rainbow trout redds, based on Equation 4.1. Standard deviations are given between parentheses.

\begin{tabular}{llllll}
\hline$z_{0}(\mathrm{~mm})$ & $C_{50}$ & $C_{65}$ & $C_{75}$ & $C_{84}$ & $C_{90}$ \\
\hline $2.0(3.0)$ & 2.0 & 1.5 & 1.2 & 1.0 & 0.9 \\
\hline
\end{tabular}

\subsection{Riffle-scale hydrodynamics}

Table 4.3 summarizes the average redd characteristics of 1853 vertical profiles measured during four sampling periods over three riffles (two for brown trout, and two 
for rainbow trout). Temperatures listed in Table 4.3, measured by the PCADP, increased throughout the day between the ranges specified. Because the PCADP sensors had to submerged, and a $5 \mathrm{~cm}$ buffer cell is required to minimize PCADP wake disturbance (Figure 3.7), actual depth-averaged velocity $(U)$ had to be interpolated using the Law of the Wall and known flow depth, shear velocity, and roughness length, assuming that the logarithmic profile extends to the water surface. Mean profile velocity $\left(U_{p}\right)$ represents the average of measured velocity cells that constitute one single profile, measured within the profile length $\left(h_{p}\right)$.

Table 4.3: Mean measured data collected from the four study riffles. Flow is estimated from stage-discharge rating curves. $\dagger-$ Bed shear calculated using Equation 2.41 and $\ddagger$-Equation 2.25. Standard deviations are given between parentheses.

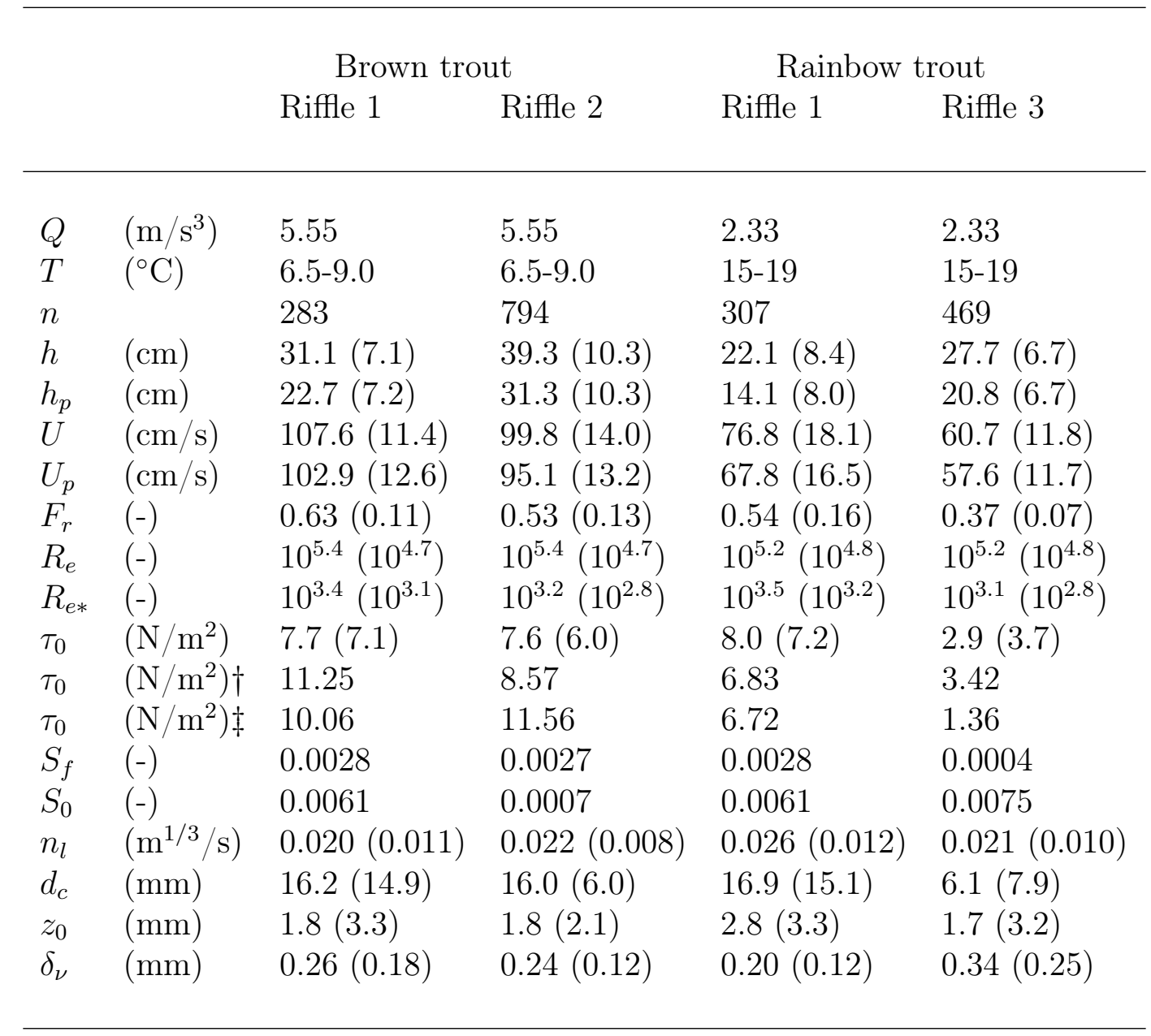

The Froude number measured at all riffles is within the range expected by Jowett [1993]. On average, Froude numbers were greater than the values collected from other redd-related studies (Figure 4.3). Although demonstrating little change among study riffles, the Reynolds number showed high variation (where the standard deviation is found to be one order of magnitude less than the mean), and appears to be most dependent on discharge. In all cases, $R_{e} \gg 2500$, hence flow 
is turbulent. The grain shear Reynolds number $\left(R_{e *}\right)$ was consistent at all study reaches yet experiences an even greater variation than $R_{e}$. In all cases, $R_{e *} \gg 70$, hence hydraulically-rough flow is present.

Three methods of calculating bed shear are compared in Table 4.3. First, actual local bed shear, related to the velocity profile slope, experienced the greatest variation, where its standard deviations is close to their mean values, i.e., having a relative error close to unity (Bevington and Robinson, 1992). The distribution of the measured bed shear was positively skewed at all riffles. Second, marked $\dagger$, bed shear is calculated based on the Einstein-Kuelegan equation (2.41) with known mean velocity, depth, and allowing $k_{s}=d_{65}$ (Einstein, 1950). Third, marked $\ddagger$, bed shear is calculated based on the DuBoys bed shear equation (2.25) with known depth and friction slope calculated from HEC-RAS ${ }^{\circledR}$ simulations (§4.4). Overall, the two methods of estimating bed shear using Equations 2.25 and 2.41 faired quite well in estimating mean measured shear. Also shown in Table 4.3, with the exception of RR1, actual bed shear was slightly overestimated by Equations 2.25 and 2.41, which is reasonable considering the positively skewed bed shear distribution. Within Table 4.3 Duboys bed shear $\left(\tau_{0} \ddagger\right)$ for RR3 must be disregarded since the HEC-RAS ${ }^{\circledR}$ simulation of RR3 produced unreasonable values at the low flow conditions experience during PCADP data collection. Once discharge approached bankfull, the HEC-RAS ${ }^{\circledR}$ simulation of RR3 predict reasonable values of shear.

Manning's $n$ calculated using the local Manning roughness coefficient $\left(n_{l}-\S 3.5 .2\right)$ yielded values far less than Arcement and Schneider's [1989] prediction of Manning's $n$ for Whiteman's creek, which was similar to approximations listed in both Morisawa [1968] and Newbury and Gaboury [1993], where $n \approx 0.050$. Equations 2.20-2.22 was closer to the local values, yet was still an overestimation. When applying the mean local roughness coefficient to the HEC-RAS ${ }^{\circledR}$ simulation, the model produced hydraulic values that best resembled observed conditions and best fit the $02 \mathrm{~GB} 008$ rating curve.

Critical particle sizes calculated during the time of sampling roughly averaged 16 $\mathrm{mm}$; therefore, in general, $d>d_{16}$ were not at risk of entrainment at flow conditions during data collection. Table 4.4 outlines other critical conditions based on the sediment character present at each study riffle, as described in \$2.3.2. Contrasting the critical velocities and critical shear of Table 4.4 to HEC-RAS ${ }^{\circledR}$ analysis $(§ 4.4)$ shows that critical conditions roughly coincide with bankfull conditions, consistent with Emmett and Wolman [2001]. In all cases, $d_{c}>1 \mathrm{~mm}$, the particle size deemed detrimental to redd success.

Table 4.3 reveals that hydraulically rough turbulent flow was present at all study riffles, where $R_{e *} \gg 70$ and $\delta_{\nu} \ll d$ (see $\S 4.1$ ). In addition, $z_{0} \ll h$ verifies that, on average, the assumption holds when integrating Equation 2.38 and the most-familiar Einstein-Keulegan forms (2.35 and 2.41).

In addition to the results of Hartley [1999] (§3), the meander geometry of Whiteman's creek and Log Pearson type III analysis (IACWD, 1982) revealed the following characteristics: $Q_{b f}=39.8 \mathrm{~m}^{3} / \mathrm{s}$ (based on WSC-02GB008 flow data, 
Table 4.4: Summary of critical shear velocity $(\mathrm{m} / \mathrm{s})$, critical velocity $(\mathrm{m} / \mathrm{s})$ and critical shear $\left(\mathrm{N} / \mathrm{m}^{2}\right)$.

\begin{tabular}{lccccccc}
\hline & & & & & & & \\
& $u_{* c}$ & $U_{c}$ & $U_{c}$ & $\begin{array}{c}\tau_{c} \\
\rho u_{* c}^{2}\end{array}$ & $790 d_{50}$ & $\begin{array}{c}\tau_{c} \\
1260 d_{50}\end{array}$ & $630 d_{50}$ \\
Equation: & 2.35 & 2.36 & 2.32 & & 2.33 & \\
\hline & & & & & & & \\
BR1 & 0.16 & 1.60 & 1.28 & 24.0 & 39.1 & 62.4 & 31.2 \\
BR2 & 0.15 & 1.58 & 1.28 & 22.3 & 36.3 & 57.8 & 28.9 \\
RR1 & 0.16 & 2.36 & 1.13 & 24.0 & 39.1 & 62.4 & 31.2 \\
RR3 & 0.14 & 1.47 & 1.17 & 20.1 & 32.6 & 52.0 & 26.0 \\
& & & & & & & \\
\hline
\end{tabular}

1961-2005, where $Q_{b f}=Q_{1.5}$-Bedient and Huber, 2002), $Q_{100}=98.4 \mathrm{~m}^{3} / \mathrm{s}$, $S_{0}=0.257 \%$, valley length surveyed $=1960.6 \mathrm{~m}$, length of thalweg surveyed $=$ $2988.4 \mathrm{~m}, \Omega=1.52$, radius of curvature $r_{c}=35.3 \mathrm{~m}$, and meander belt width $=$ $184.8 \mathrm{~m}$.

\subsection{On the physical habitat of spawning brown and rainbow trout}

Figure 4.3 contrasts a collection of depths and depth-averaged velocities proximal to redds from the current and previous studies. Figure 4.3 also includes Reynolds and Froude numbers which are similar to Figure 2.3 but now include the summary of investigation included in this research. Whether comparing depth or velocity, the reviewed literature shows results that vary widely and is ultimately dependent on the discharges present during the time of sampling. It must be noted that the measured values presented in Figure 4.3 are all within channels that can be waded, limiting the upper limits of investigation.

\subsubsection{Local-scale spawning assessment}

To quantify inter-riffle spawning preference, the profiles gathered were divided into five classes: profiles measured over the pit (Pit), over the tailspill (TS), within a $1 \mathrm{~m}$ buffer proximal to each redd (Buf.), in areas where redd construction was attempted yet abandoned (Att.), and all other remaining profiles (Other) - as shown in Figures 4.4-4.6. In all cases, the measured three-dimensional velocity field exhibited a high degree of spatial variability. Mean profile velocities (Figure 4.4a) measured within the areas selected for spawning are indistinguishable from the remaining profiles, with the exception of profiles measured over redd pits, where mean 

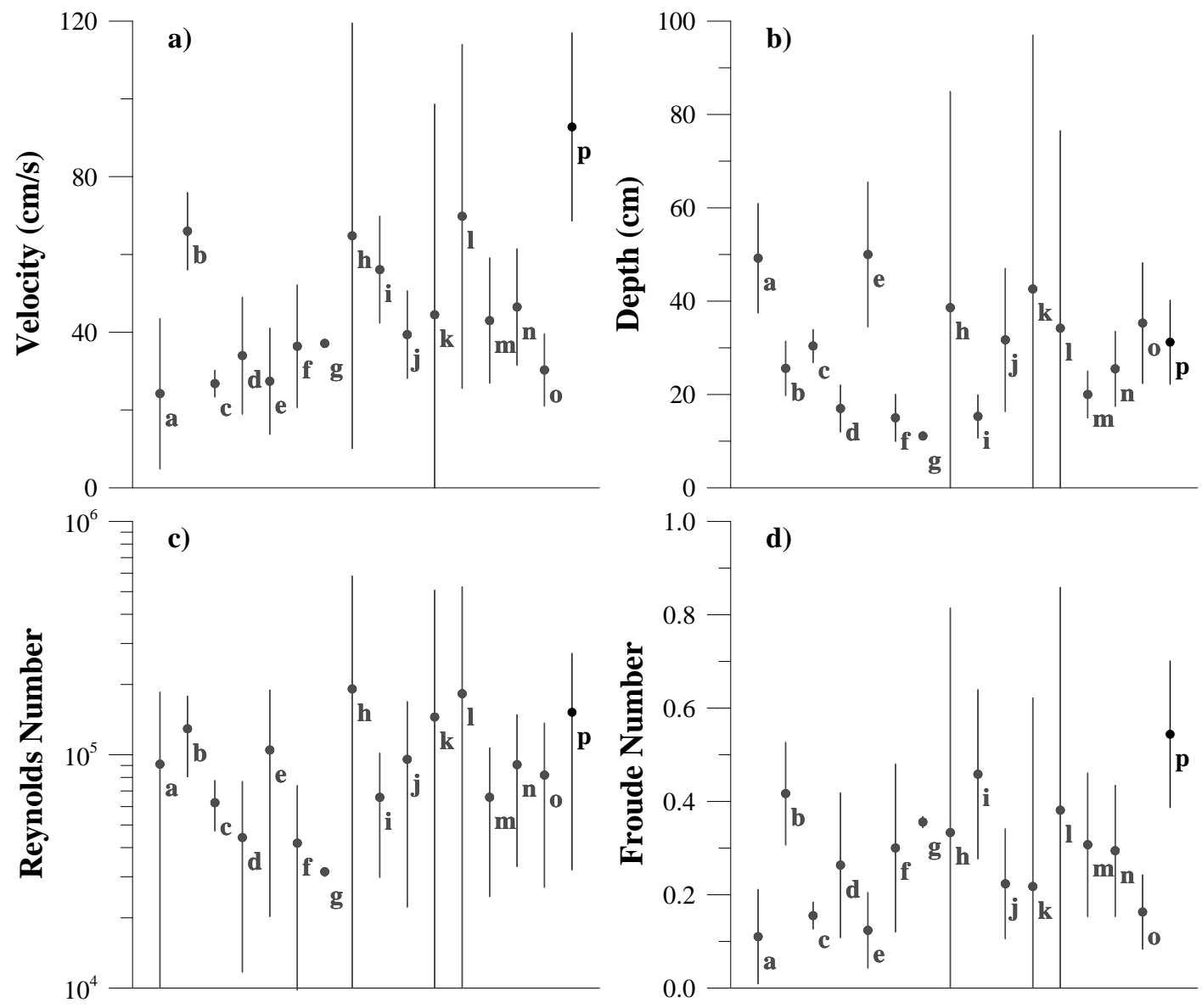

Figure 4.3: Hydraulic data collected proximal to redds from various works listed in Table 4.5. a) Average velocity, b) depth, c) Reynolds Number, and d) Froude Number. Bars indicate \pm standard deviation. 
Table 4.5: List of sources as labelled in Figure 4.3.

a. Bernier-Bourgault and Magnan, 2001, (brook trout), $n=16$

b. Briggs, 1953, (steelhead trout), $\mathrm{n}=12$

c. Essington et al. 1998, (brown trout), $\mathrm{n}=$ No Data

d. Grost et al., 1990, (brown trout), $n=80$

e. Heggberget, 1991, (brown trout), $\mathrm{n}=125$

f. Kondolf et al., 1993, (brown \& rainbow trout), $n=25$

g. Ottaway et al., 1981, (brown trout), $\mathrm{n}=264$

h. Sams and Pearson, 1963, (steelhead trout), $n=49$

i. Schmetterling, 2000, (cutthroat trout), $n=32$

j. Shirvell and Dungey, 1983, (brown trout), $\mathrm{n}=118$

k. Smith, 1973, (brown trout), $\mathrm{n}=115$

l. Smith, 1973, (rainbow trout), $\mathrm{n}=51$

m. Sorenson et al., 1995, (brown trout), $\mathrm{n}=12$

n. Witzel and MacCrimmon, 1983, (brown trout), $\mathrm{n}=110$

o. Zimmer and Power, 2005, (brown trout), $\mathrm{n}=159$

p. This study, (brown \& rainbow trout), $n=1001$

profile velocities decreased due to the sudden drop in bed elevation (Figure 4.4b). The Reynolds number (Figure 4.4c) again exhibits little correlation with redd positioning, with the exception of BR1, which is most likely due to measurement error, since measurements were taken over a two-day period. The Froude number (Figure $4.4 d$ ) shows less inter-riffle variation, yet again, shows little correlation to redd positioning. The Froude numbers ranged within values expected for gravel bed riffles studied during wadable flow conditions except for RR1, where supercritical flow was present above the tailspill and within the $1 \mathrm{~m}$ redd-buffer, possibly due to the shallow low-flow conditions present at the time of sampling, where measurable velocity profile points were limited.

Shear-related variables $\left(\tau_{0}, u_{*}, R_{e *}, d_{c}\right)$ demonstrate a minor, yet distinguishable decrease in areas chosen by spawning fish (TS, Buf., and Att. of Figure 4.5), and appears to show some dependence on the Froude numbers present (e.g., contrast the reduction in $F_{r}$-Figure $4.4 \mathrm{~d}$-of RR3 with measured shear-Figure 4.5 ). All shearrelated variables, however, demonstrate the greatest variation, having relatively high standard deviations, especially when water depths are shallow. Particle sizes at risk of being entrained at low flow conditions are, in all cases, below the $25^{\text {th }}$ percentile by mass of the pavement sampled (Figure $4.5 d$ ). In addition, all critical particle sizes were above $1 \mathrm{~mm}$, the particle size hazardous to fry development; therefore, fines hazardous to fry development should not have been able to settle, even at the low flow conditions present during sampling. The grain shear Reynolds number $\left(R_{e *}\right)$ does not demonstrate any positive correlation with redd site selection 
- $\mathrm{BR} 1 \cdot \mathrm{BR} 2 \cdot \mathrm{RR} 1 \times \mathrm{RR} 3$
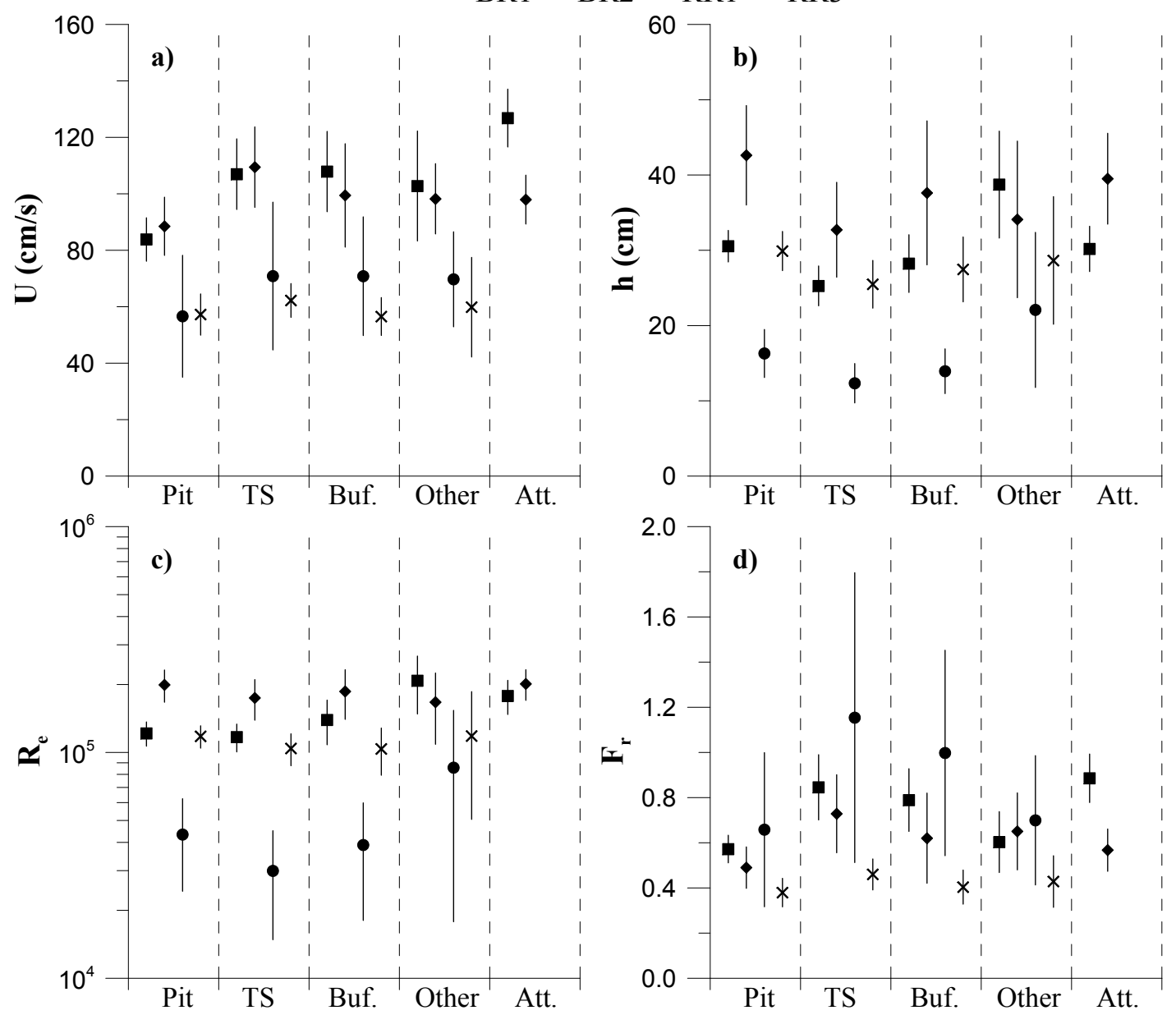

Figure 4.4: Averages of a) mean profile velocity, b) water depth, c) Reynolds number, and d) Froude number stratified by riffle location. Whiskers indicate \pm standard deviation. BR1 signifies Brown trout Riffle 1, RR1 signifies Rainbow trout Riffle 1. 

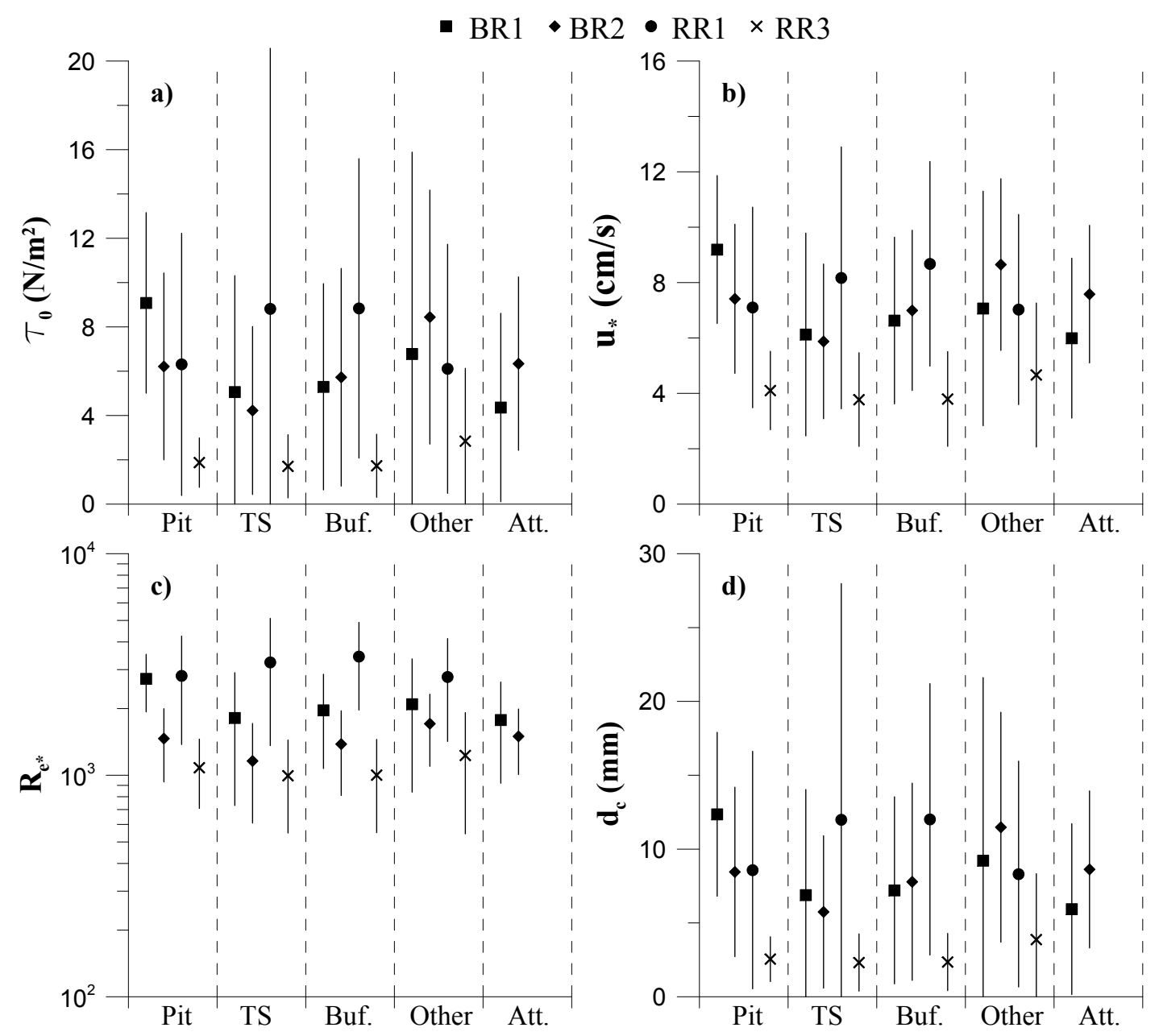

Figure 4.5: Averages of a) bed shear, b) shear velocity, c) grain shear Reynolds number, and d) critical particle size stratified by riffle location. Whiskers indicate \pm standard deviation.

(Figure $4.5 c$ ). Most importantly, $R_{e *}$ was consistently well above the threshold of 70, which characterizes hydraulically rough turbulent flow conditions (Shields, 1936) at all study sites.

Turbulent kinetic energy per unit area of streambed (Equation 3.16) proves to be the most revealing hydrodynamic characteristic that differentiates chosen redd locations from the surrounding riffle. Figure 4.6 illustrates that there is a considerable decrease in secondary flow above and surrounding the tailspill. Locations surrounding attempted, yet uncompleted, redd construction also show the same trend, suggesting a pre-spawning criterion of consistently linear flow. The high variation of the profiles categorized as "other" in Figure 4.6 illustrate two important characteristics of the measured flow regimes: First, it shows that assuming depth-wise homogeneity (e.g., when employing the use of two-dimensional planform hydraulic models) is a major simplification. Second, the degree of depth-wise heterogeneity is, again, highly variable spatially in the planform perspective. Together, as expected, 
the flow fields, measured in wadeable/low-flow conditions, exhibit high spatial variability in all three spatial dimensions. Turbulent kinetic energy per unit area of streambed was lowest above redd tailspills, perhaps adding further protection to the redd form throughout its existence. Locations where spawning brown trout performed initial cutting yet later abandoned their site consistently shows similar hydrodynamic characteristics to areas surrounding completed redds; further confirming that some aspect of local physical habitat dictates redd site selection.

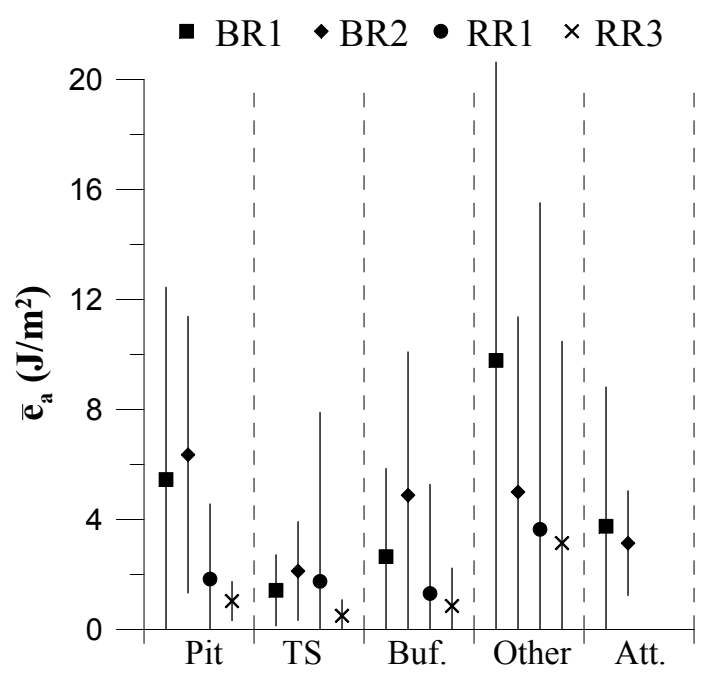

Figure 4.6: Mean turbulent kinetic energy per unit area of streambed stratified by riffle location. Whiskers indicate \pm standard deviation.

Critical swimming velocities $\left(u_{\text {crit }}\right)$, discussed in $\S 2.2 .1$, are calculated using HEC-RAS ${ }^{\circledR}$ one-dimensional average hydraulic metrics of $U, h$, and $\tau_{0}$ at discharges occurring at the time of spawning. Depth-averaged velocities, however, are not the velocities that spawning fish are actually exposed to and thus cannot be compared directly with $u_{\text {crit }}$. The velocities fish are exposed to are nearest to the sediment-water interface, where, due to bed shear, the velocities are notably reduced; this reduction in velocity is commonly described in biology as the focal- or nose-level velocity (Stratzner et al., 1988). This nose-level velocity $\left(u_{f}-[L / T]\right)$ is here assumed to occur at $7.5 \mathrm{~cm}$ above the streambed, a median value between the $5 \mathrm{~cm}$ assumed by Ottaway et al. [1981] and Sorenson et al. [1995] and the $10 \mathrm{~cm}$ assumed by Orcutt et al. [1968], Smith [1973], Witzel and MacCrimmon [1983a], and Bernier-Bourgault and Magnan [2002]. Therefore, nose-level velocities defined as $u_{f}=\bar{u}(z=7.5 \mathrm{~cm})$, are calculated from the Law of the Wall (§2.3.3), where roughness length is determined by

$$
z_{0}=h e^{-\left(\frac{U \kappa}{u_{*}}+1\right)}
$$

and is illustrated in Figure 4.7.

In this study, the 2006 brown trout spawning season coincided with flows greater than baseflow, $\left(Q>12 \mathrm{~m}^{3} / \mathrm{s}\right)$, which reoccurs at this reach roughly once a year. 

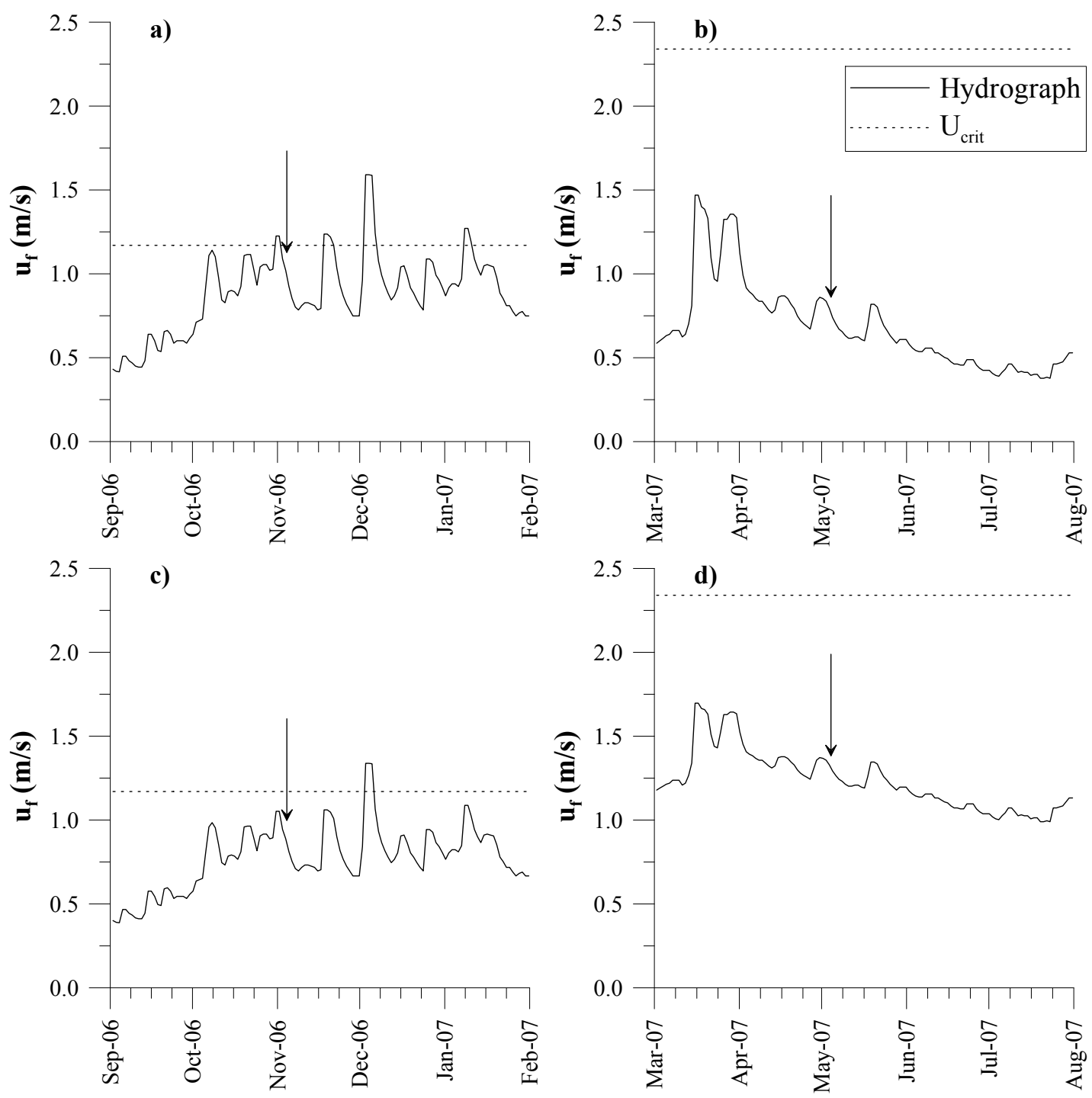

Figure 4.7: HEC-RAS ${ }^{\circledR}$ predicted nose-level velocities, where $u_{f}=\bar{u}(0.075)$, at study sites a) BR1, b) RR1, c) BR2, and d) RR3, superimposed by critical swimming speeds of brown trout $-u_{c r i t, b}$ and rainbow trout- $u_{c r i t, r}$. Arrows indicate likely time of spawning, based on field survey. 


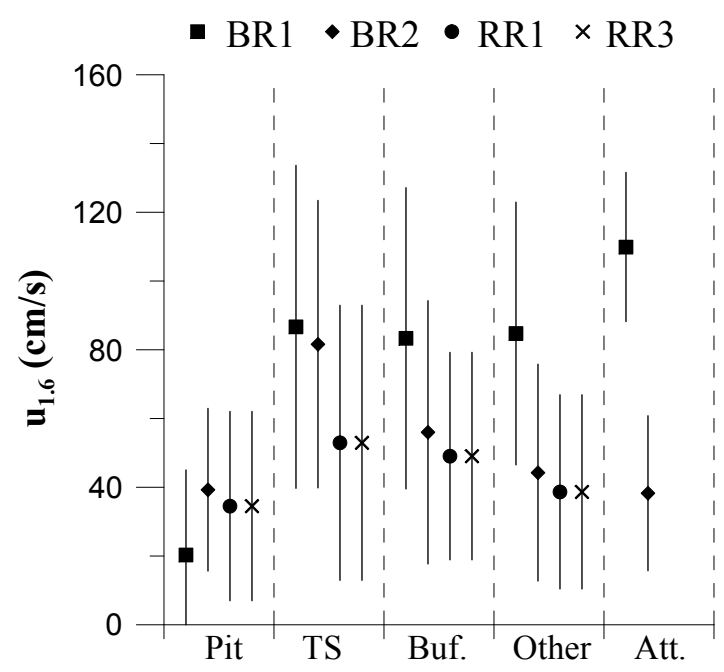

Figure 4.8: Average velocity from $1.6 \mathrm{~cm}$ above the streambed $\left(u_{1.6}\right)$, stratified by riffle location. Whiskers indicate \pm standard deviation.

Near-bank velocities of riffle 1 were in excess of $1.4 \mathrm{~m} / \mathrm{s}$ and all study riffles were unwadeable. Turbidity in Whiteman's creek at the time of spawning prevented any off-shore redd identification. From Figure 4.7, it is evident that at the time of spawning, neither species were restricted due to channel nose-level velocities.

Reiser [1976] and Schmetterling [2000] observed that velocities significantly increased over the tailspill and decreased within the pit, relative to the approach velocities, an observation consistent with Figure 4.4a. Jones and Ball [1954], Grost et al. [1990], and Beard and Carline [1991] noted pooling, a significant reduction of velocity, within the pit below the original undisturbed streambed grade. Pit pooling is important in the fish attaining high fertilization success as it enables the female's ova and the male's milt to settle to the bottom of the pit without being swept away by the currents. Orcutt et al. [1968], Reiser [1976], and Ottaway [1981] observed that pit velocities ranged between $0.3-1.0 \mathrm{~m} / \mathrm{s}$, and were also observed to be notably slower than the surrounding riffle velocities. Schmetterling [2000] further added that the presence of low-velocity pits provided the female with a place to rest while remaining in close proximity to the redd, despite the higher surrounding velocities. Skin-velocities measured $1.6 \mathrm{~cm}$ above the streambed $\left(u_{1.6}\right)$, showed a significant difference between pit and tailspill (Figure 4.8), consistent with the documented observations mentioned.

Hobbs [1937], Burner [1951], and Stuart [1953a] observed fertilized eggs entering the interstitial spaces of the tailspill, which led them to subject redds to dye tracing experiments to examine pathway connections within the tailspill. Stuart [1953a] observed dye entering the redd at the upstream end of the tailspill and exiting downstream of the redd's crest, flowing through regions occupied by fertilized eggs. $\mathrm{Wu}$ [2000] realized that the works of Thibeaux and Boyle [1987] and Jobson and Carey [1989], regarding the hyporheic exchange among bedforms analogous in shape to the tailspill, found substantial interstitial flow within the bedform, as illustrated 
in Figure 4.9. Interstitial flow within the bedform is attributed to flux variations at the sediment-water interface, consistent with Bernoulli's principle.

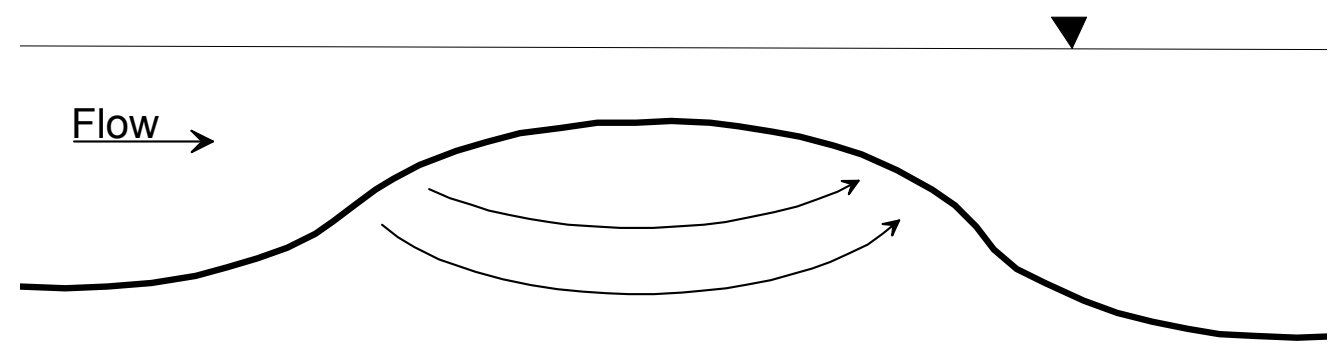

Figure 4.9: Interflow and hyporheic exchange within the longitudinal form of the tailspill. Modified from Cooper [1965], Vaux [1968], Thibeaux and Boyle [1987], Elliott and Brooks [1997a,b], Packman et al. [1997], and Wörman et al. [2002].

Although pressure gradients were never measured, velocity gradients were consistent with the aforementioned bedform studies. This differential velocity may create the pressure differential required to provide a mechanism for driving the interstitial flow necessary for embryonic success, similar to interflow and hyporheic exchange among bedforms. This observation, however, requires further investigation.

Hobbs [1937] and Burner [1951] also found a reduction in velocities within the pit, but maintained that the pit flows were circulating (Figure 4.10). These observations were based upon ova moving toward and settling closest to the upstream end of the pit, against the direction of the approaching flow. Upon further inspection with potassium permanganate crystals, Hobbs [1937] and Burner [1951] observed that the water within the pit quickly mixed with the dye, an observation they attributed to circular currents; however, neither study physically measured the presence of circular currents.

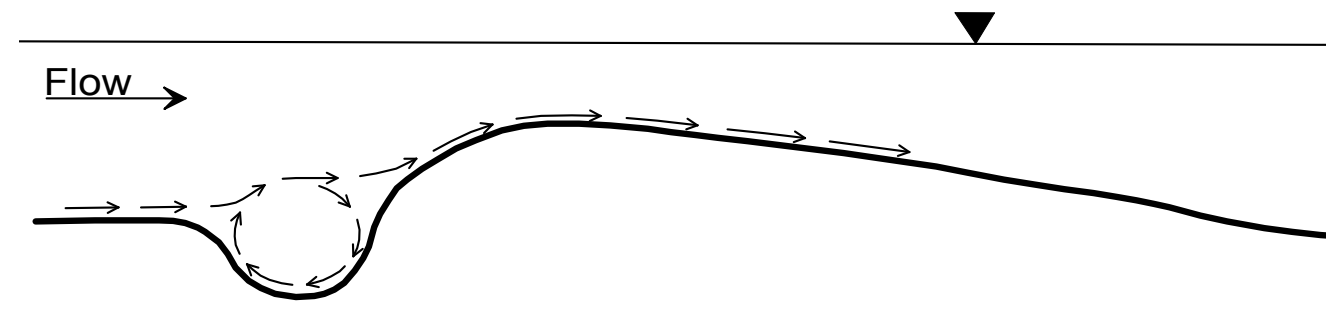

Figure 4.10: Illustration of circular flow within the pit as proposed by Hobbs [1937], Burner [1951] and Reiser [1976].

From the profile data collected, $z$-direction (vertical) velocities were analyzed to identify the presence of circular flow within the pit. For each profile, the average of the collected $z$-direction velocity standard deviations $\left(\sigma_{z}\right)$ is presented in Figure 4.11. If circular flow is present, there should be a notable increase in $\sigma_{z}$ for profiles 


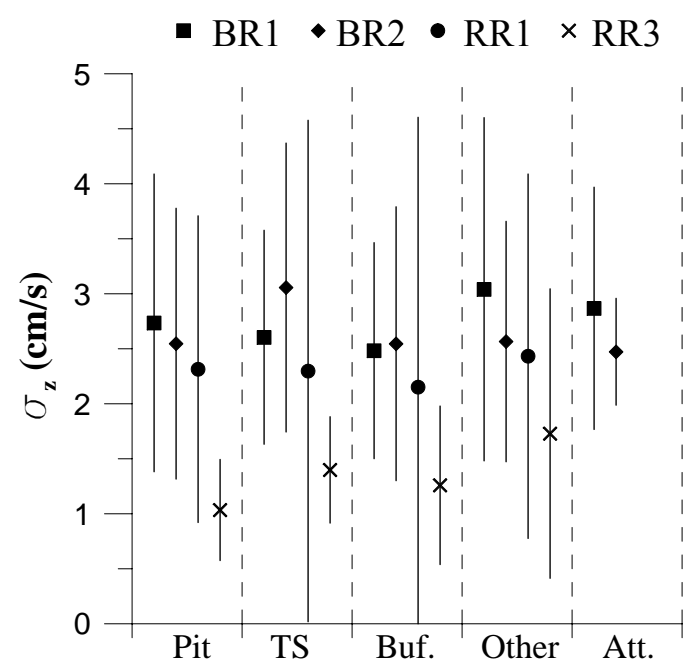

Figure 4.11: Averages of profile vertical velocity standard deviation stratified by riffle location. Whiskers indicate \pm standard deviation.

measured at pit locations, since circular flow illustrated in Figure 4.10 implies that an increase change in $z$-direction velocities $\left(u_{z}\right)$ within the pit below the original streambed grade. According to this described method of analysis, circular flow was not present within any of the pits measured for the current study.

\subsection{One-dimensional hydraulic reach-scale analysis}

The collected data presents an opportunity to compare local-scale hydrodynamics to the predictive capabilities of reach-scale hydraulic metrics employed by onedimensional models such as HEC-RAS ${ }^{\circledR}$ (commonly used by river engineers for flood flow analysis and used in this study), and PHABSIM ${ }^{\circledR}$ (employed by lotic ecologists for habitat suitability analysis, a module of the instream flow incremental methodology-IFIM-Bovee, 1982; Stalkner et al., 1995). Through HEC-RAS ${ }^{\circledR}$ analysis, hydraulic conditions at high discharge events that would normally be unsuitable for wadeable field measurements can be simulated and analyzed at each spawning riffle. Figures 4.12 through 4.14 provide an illustrative method of viewing HEC-RAS ${ }^{\circledR}$ results. For 100 simulations the discharge ranging from $0<Q \leq$ $Q_{100}$ at equally distributed intervals, HEC-RAS ${ }^{\circledR}$ results of each cross-section are represented by a box-and-whisker plot.

Figure 4.12 illustrates unit stream power, total bed shear, and total velocity predicted along the Whiteman's creek study reach. Essentially, if bankfull conditions coincide with the maximum values of the reported variables in Figure 4.12, bankfull discharge would be considered the effective discharge, and floodplain connectivity can be assessed. Figure 4.13 illustrates channel bed shear and channel Froude numbers along with the study reach longitudinal profile. HEC-RAS ${ }^{\circledR}$-simulated channel metrics are the conditions expected to occur directly on spawning riffles, which can 
be analyzed at various discharge events. Three road crossings are present within the modeled reach and are located on Figure 4.13c.

Unit stream power (Equation 2.28), on average, remained fairly constant throughout the reach, except in cases where road crossings are located. For most crosssections, with the exception of road crossings, $\omega_{\text {max }} \approx \omega_{b f}$, revealed that maximum sediment transport coincides with bankfull discharge. The distribution of total bed shear was slightly more-varied; however, all three spawning sites in addition to two other sites known to host spawning (located at a longitudinal distance of $900 \mathrm{~m}$ and $1200 \mathrm{~m}$ ) had their maximum shear occur at bankfull flow. Hence, redd site selection at Whiteman's creek appears to coincide with locations with adequate floodplain access.

HEC-RAS ${ }^{\circledR}$ analysis also reveals that for 100 different discharge simulations ranging between $0<Q \leq Q_{100}, \tau_{0, \max }$ for study riffles 1,2 , and 3 are $34.3 \mathrm{~N} / \mathrm{m}^{2}$, $29.8 \mathrm{~N} / \mathrm{m}^{2}$, and $31.8 \mathrm{~N} / \mathrm{m}^{2}$, resulting in a critical particle size $d_{c, \max }$ of $72.0 \mathrm{~mm}$, $62.6 \mathrm{~mm}$, and $66.8 \mathrm{~mm}$, respectively. Thus, up to a 100-year flood, riffles 1 and 2 are at risk of having particles of the smallest $65^{\text {th }}$ percentile becoming entrained, while riffle 3 is at risk of have $95 \%$ of the sediment becoming entrained. It must be noted, however, that since the redds' substrate could not be directly measured, it is likely that, through redd construction, a process that reduces the substrate fine content, $d_{c}$ will be overestimated. Table 4.6 summarizes bed shear $\tau_{0}$ and critical particle size $\left(d_{c}\right)$, calculated using Equation 3.5, at simulated discharges $Q_{b f}$ and $Q_{100}$, and at $Q=46.1 \mathrm{~m}^{3} / \mathrm{s}$-the highest discharge that occurred at Whiteman's Creek throughout the entire study period.

Table 4.6: Bed shear $\left(\mathrm{N} / \mathrm{m}^{2}\right)$ and critical particle size ( $\left.\mathrm{mm}\right)$ simulated using HEC$\mathrm{RAS}^{\circledR}$ at $Q_{b f}, Q_{100}$, and at the maximum discharge at Whiteman's creek throughout the time of sampling $\left(Q_{\max }=46.1 \mathrm{~m}^{3} / \mathrm{s}\right)$.

\begin{tabular}{lcccccr}
\hline & \multicolumn{2}{c}{$Q_{\max }$} & \multicolumn{2}{c}{$Q_{b f}$} & \multicolumn{2}{c}{$Q_{100}$} \\
& $\tau_{0, \max }$ & $d_{c, \max }$ & $\tau_{0, b f}$ & $d_{c, b f}$ & $\tau_{0,100}$ & $d_{c, 100}$ \\
& & & & & & \\
\hline & & & & & & \\
Riffle 1 & 25.3 & 53.1 & 27.0 & 56.7 & 40.9 & 85.9 \\
Riffle 2 & 16.7 & 35.1 & 22.1 & 46.4 & 42.5 & 89.3 \\
Riffle 3 & 24.9 & 52.3 & 35.4 & 74.3 & 48.2 & 101.2
\end{tabular}

Average total velocities remained fairly constant along the surveyed reach near the study riffles (again, with the exception of road crossings), which is expected since the reach has a consistent longitudinal slope and flood plain access. At all known spawning sites, channel velocity exceeded rainbow trout critical swimming velocity $\left(u_{c r i t, r}\right)$ generally at $Q \geq Q_{b f}$. It appears, however, that brown trout are 


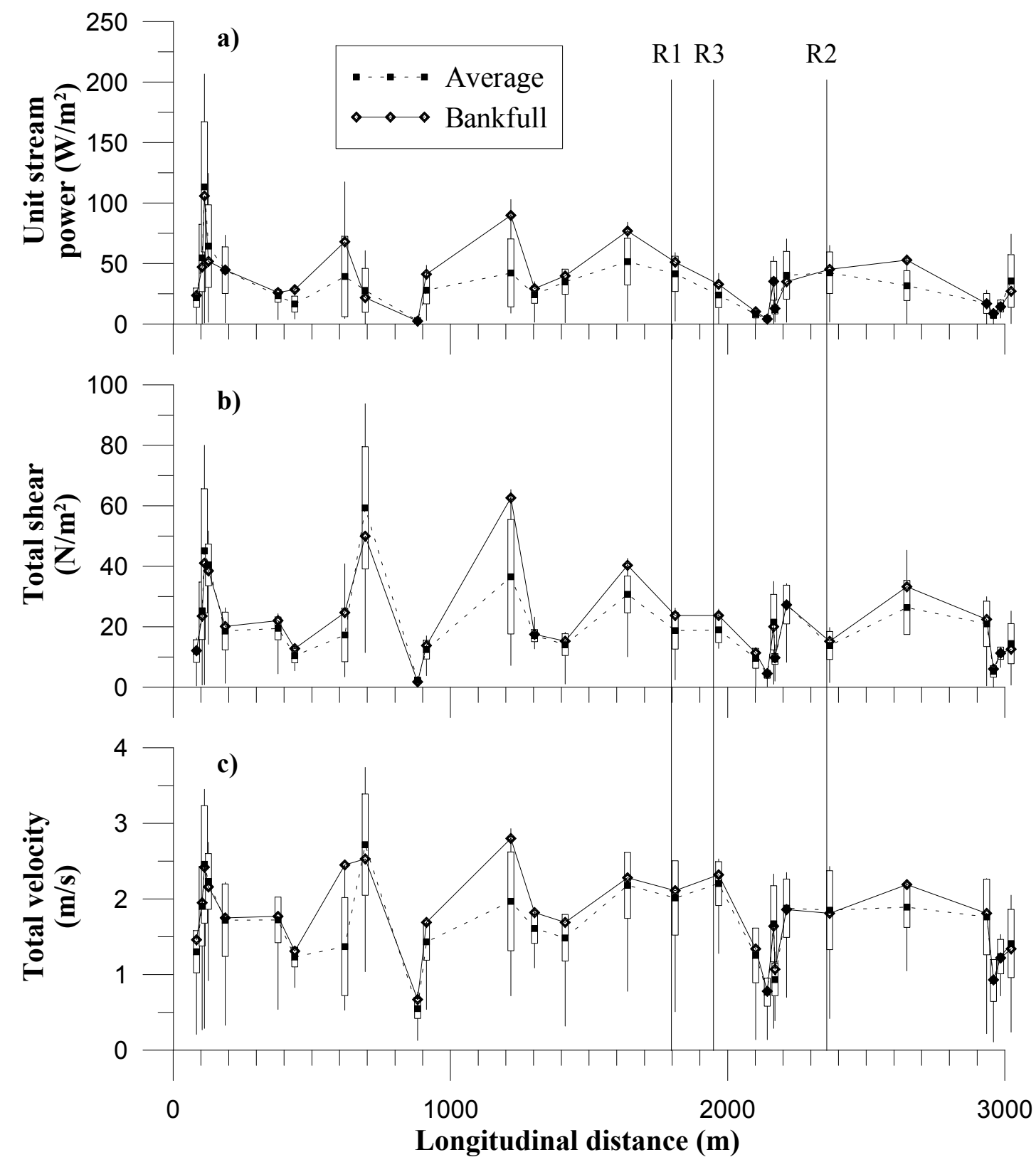

Figure 4.12: Longitudinal trend for Whiteman's creek as predicted by HEC-RAS ${ }^{\circledR}$. Total velocity, total shear, and unit stream power per unit area were modeled from $0 \leq Q \leq Q_{100}$ at 100 equal event discharges. Box limits are \pm standard deviation; whisker limits are minimum and maximum values. Locations of study sites are indicated. 

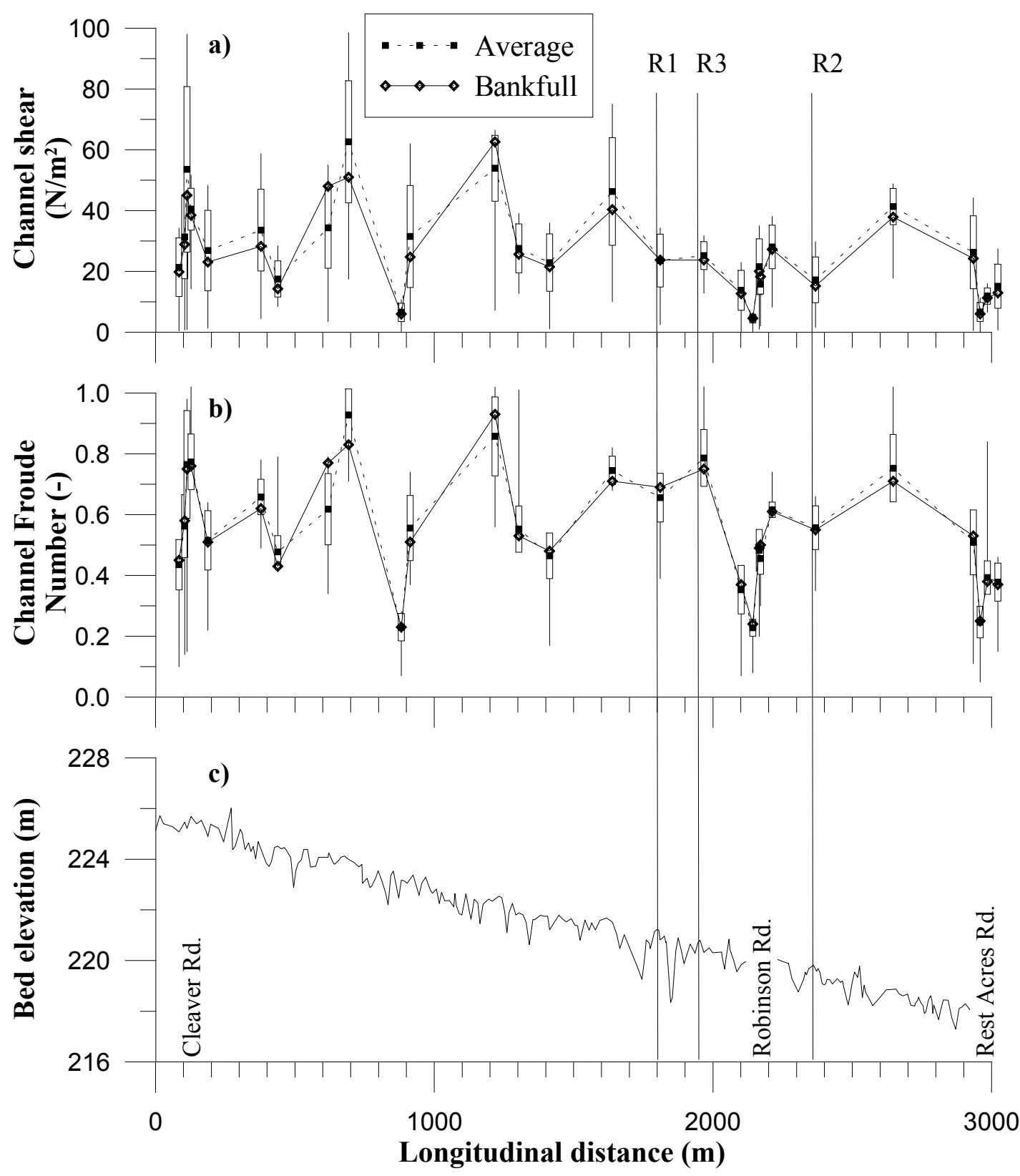

Figure 4.13: Longitudinal trend for Whiteman's creek as predicted by HEC-RAS ${ }^{\circledR}$. a) Channel shear and b) channel Froude Number were modeled from $0 \leq Q \leq Q_{100}$ at 100 equal event discharges. Box limits are \pm standard deviation; whisker limits are minimum and maximum values. Locations of study sites are indicated. c) Study reach longitudinal profile. 


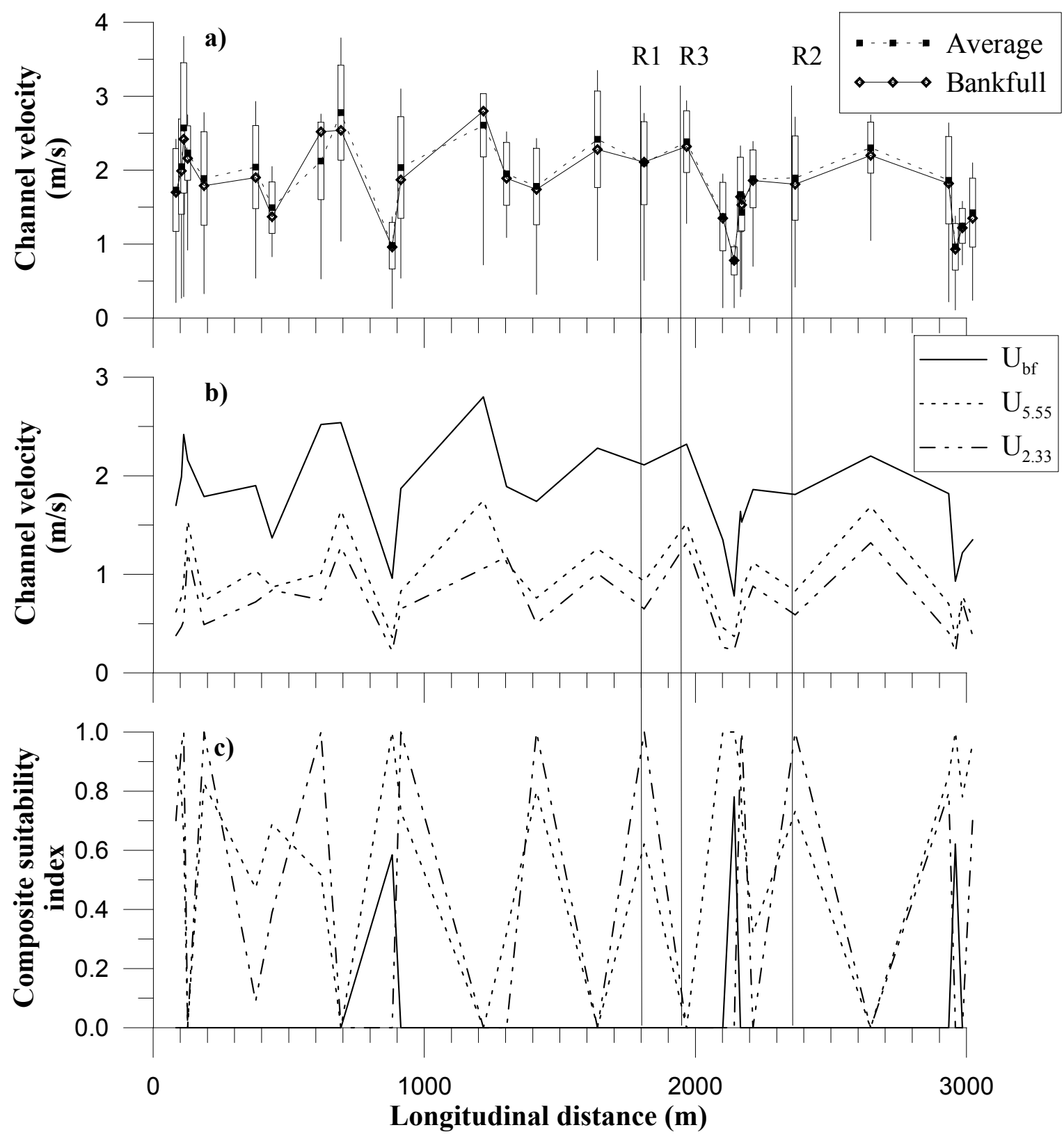

Figure 4.14: Longitudinal trend for Whiteman's creek as predicted by HEC-RAS ${ }^{\circledR}$. a) Channel velocity was modeled from $0 \leq Q \leq Q_{100}$ at 100 equal event discharges. Box limits are \pm standard deviation; whisker limits are minimum and maximum values. Locations of study sites are indicated. b) Predicted channel velocity at $Q=Q_{b f}, Q=5.55 \mathrm{~m}^{3} / \mathrm{s}$, and $Q=2.33 \mathrm{~m}^{3} / \mathrm{s}$-corresponding to the discharges experienced during PCADP sampling periods. c) Riffle-scale composite habitat index calculated from HEC-RAS ${ }^{\circledR}$ predicted channel velocity and shear at $Q=Q_{b f}$, $Q=5.55 \mathrm{~m}^{3} / \mathrm{s}$, and $Q=2.33 \mathrm{~m}^{3} / \mathrm{s}$. 
limited by the flow conditions present, where a $u_{c r i t, b} \approx 1.2 \mathrm{~m} / \mathrm{s}$ would be overcome during most of the simulated flow conditions.

Composite habitat indices $\left(C_{i}\right)$, based in the geometric mean method-Equation 2.10-and using the HEC-RAS ${ }^{\circledR}$ predicted channel velocities and depths, were calculated for each cross-section at discharges $Q=Q_{b f}, Q=5.55 \mathrm{~m}^{3} / \mathrm{s}$, and $Q=2.33$ $\mathrm{m}^{3} / \mathrm{s}$ (Figure $\left.4.14 \mathrm{c}\right)$ ). These indices appeared to switch drastically at each successive morphological feature, where it appears that, at Whiteman's Creek, every other riffle is suitable for spawning at low flow conditions. The indices also tended to decrease with increasing discharge; whereas for during bankfull discharge events $\left(Q=Q_{b f}\right)$, with the exception of three locations, $C_{i}$ was nil for the entire reach. Weighted Usable Area (WUA) for spawning rainbow and brown trout, calculated using Equation 2.8 and the composite habitat indices presented in Figure 4.14c, is presented for the entire surveyed reach, following the methods of Waddle [2001] (Figure 4.15). Results from the WUA analysis demonstrate that suitable habitat should exist at discharges well above bankfull. The only discrepancy between this method (incorporating HEC-RAS ${ }^{\circledR}$ ), and the WUA normally calculated using PHABSIM ${ }^{\circledR}$, is that the depths and velocities are taken as the cross-sectional averages; therefore, slower and shallower sections of the channel, which may exist near the banks, are ignored. If the near bank velocities and depths were to be incorporated (following the methods of Waddle [2001], the WUA values should only increase. Thus, the method used in this thesis should be considered a conservative estimate.

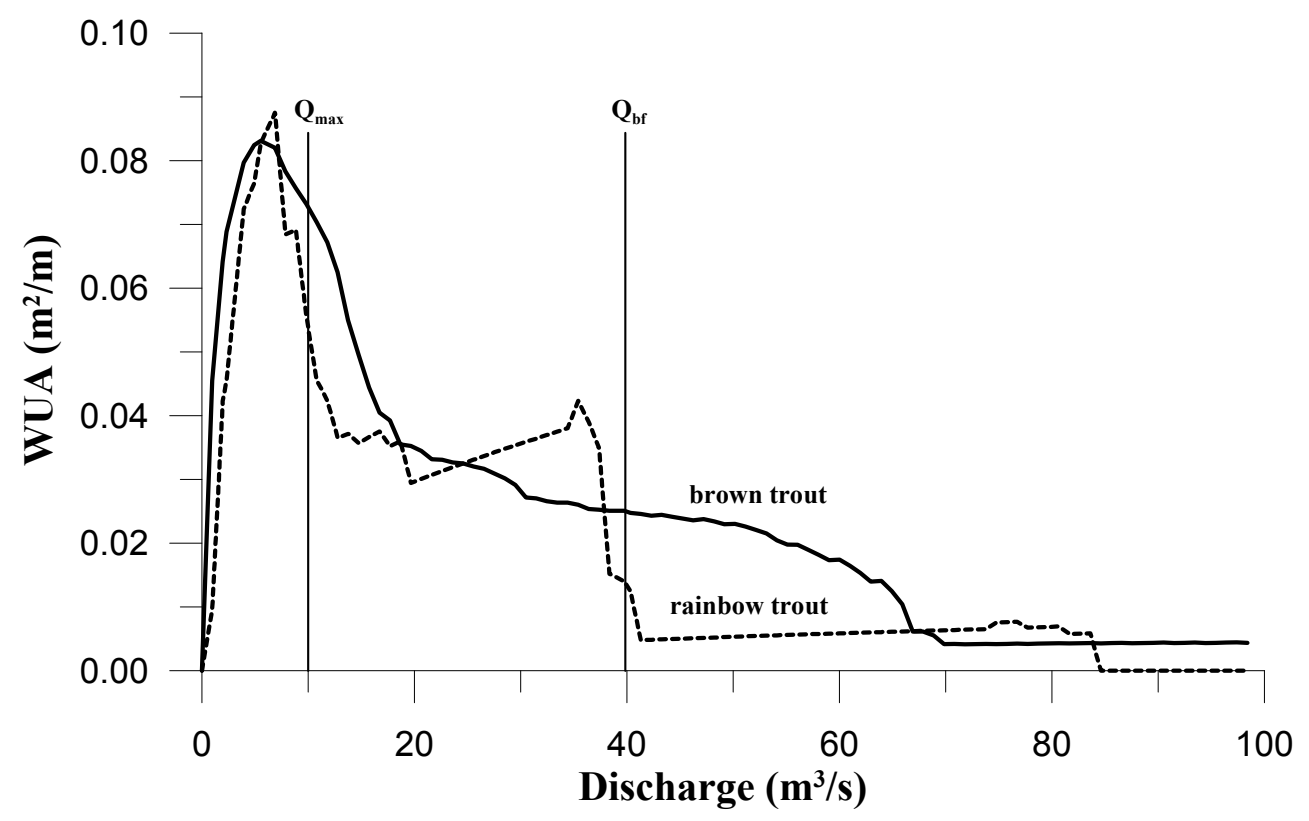

Figure 4.15: Brown and rainbow trout Weighted Usable Area at Whiteman's Creek. $Q_{\max }$ is the discharge related to the maximum wadeable velocity.

Overall, the HEC-RAS ${ }^{\circledR}$ predictions of hydraulic conditions did a fair job of 

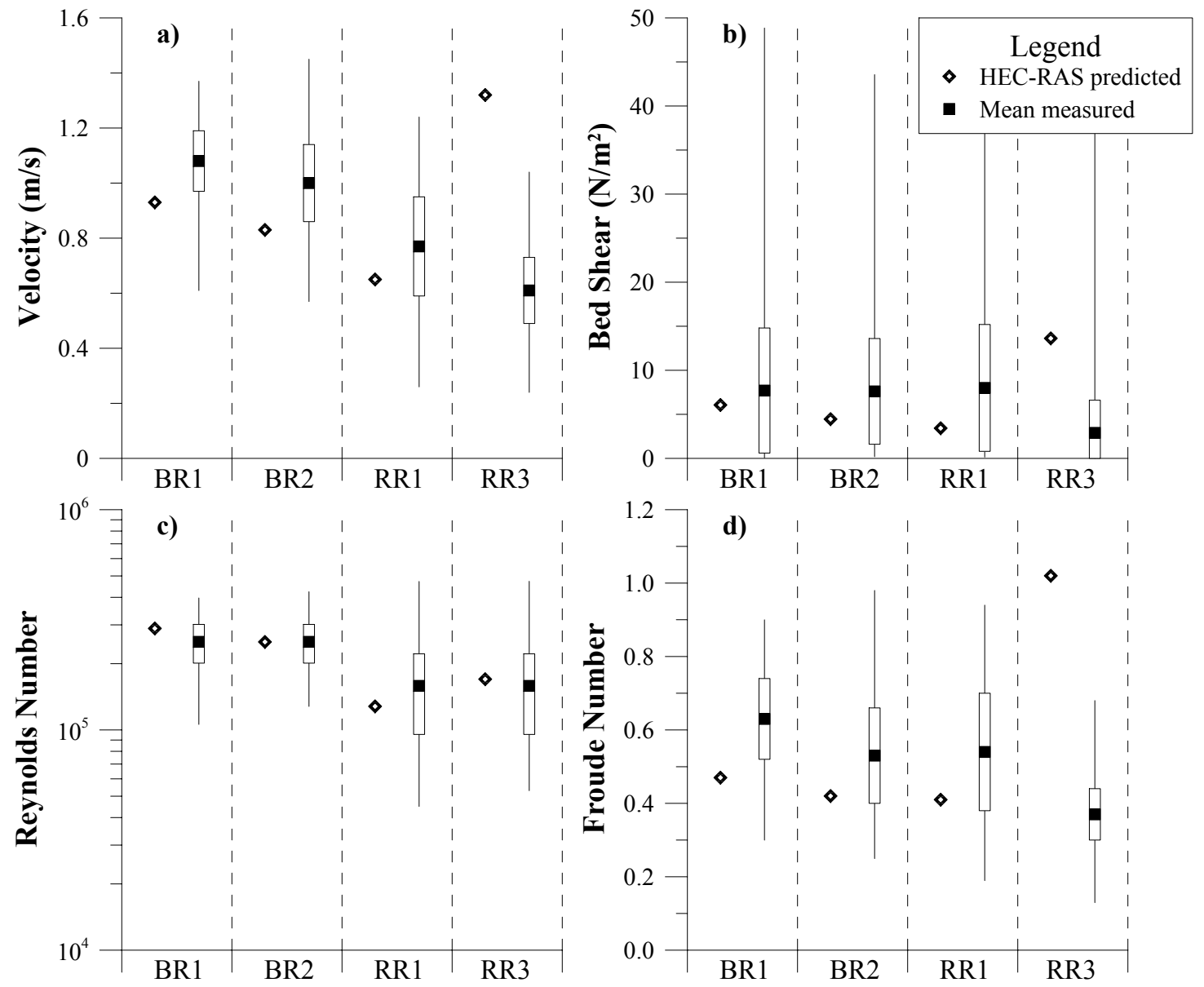

Figure 4.16: Comparison of HEC-RAS ${ }^{\circledR}$ predictions to a) mean measured velocity, b) mean measured bed shear, c) Reynolds number, and d) Froude number, at each study riffle at experienced discharge (BR1, BR2-Q $=5.55 \mathrm{~m}^{3} / \mathrm{s} ; \mathrm{RR} 1$, $\left.\mathrm{RR} 3-Q=2.33 \mathrm{~m}^{3} / \mathrm{s}\right)$. Box indicates \pm standard deviation. Whiskers indicate minimum/maximum measured values. 
predicting measured shear, velocity, and depth at flow conditions present during the time of sampling (Figure 4.16). Channel velocity predicted by HEC-RAS ${ }^{\circledR}$, at the flow conditions present while sampling, was underestimated by more than a standard deviation of the empirical measurements. (Results at RR3 must be disregarded at the low flow conditions $\left(Q<10 \mathrm{~m}^{3} / \mathrm{s}\right)$ due to unrealistic HECRAS $^{\circledR}$ outputs.) Shear, on the other hand, was predicted quite well, considering the high variation of the empirical data.

\subsection{Riffle-scale spawning assessment}

Hydrodynamic characterization up to this point has revealed high variation of measured data. Two-dimensional planform analysis was performed to investigate the spatial distribution of the hydrodynamic properties typically used in physical habitat assessment. All of the study riffles revealed a high degree of spatial heterogeneity, as expected according to Giller and Malmqvist's [1998] definition of lotic systems. What is most revealing is that the field measurements can vary within short distances, and that during the time of sampling this heterogeneity was indistinguishable through visual observation. It must be added that these field measurements, and similar to the methods of the literature reviewed, were taken in safe, calm, and wadeable conditions and will not provide insight to the hydrodynamics during high flow events.

As an example of riffle heterogeneity, Figures 4.17 and 4.18 illustrate the spatial distribution of depth-averaged velocities, where an increase of roughly $40 \mathrm{~cm} / \mathrm{s}$ can occur within a few meters, regardless of redd construction activity. The velocities measured at redd locations and at areas of attempted redd construction are not specific to the location selected by the brown and rainbow trout; thus, the use point-velocities would have been inconclusive. Similar conclusions can be made with respect to Froude number (Figures 4.19 and 4.20). Profile velocity and Froude number, however, consistently increased above the tailspill and decreased within the pit, with respect to the surrounding velocity profiles. The hydraulics atop areas where redd construction was attempted were similar to that found atop redd tailspills. Froude number distribution is quite similar to the velocity distribution. Pits can be characterized as having Froude numbers range from 0.30-0.45, whereas tailspills typically exhibits Froude numbers approaching unity. Rainbow trout redds at RR3, being the exception, is characterized by a consistently low $F_{r}$, perhaps as a result of the relatively low local bed slope, low velocity, and high depth. The extent of the variation of both mean velocity, Froude number, and depth were within expected ranges, however, from Figures 4.17 and 4.18 the planform distribution of this variation appears to be quite random. Therefore, it cannot be said the variation is dependent of channel form, where increased velocities expected near the thalweg and away for the banks would be the cause this variation.

The Reynolds number begins to show a trend toward relatively low-turbulent regimes surrounding redd locations (Figures 4.21 and 4.22). At any point, flows 
along each riffle were turbulent, where $R_{e} \gg 2500$. It is not clear how Reynolds number affected redd-site selection. At every study riffle, redds and redd-attempts were located away from the regions of relatively high $R_{e}$-this is most apparent with rainbow trout (Figure 4.22). Brown trout (Figure 4.21), on the other hand, were less discriminate to high $R_{e}$ conditions. Riffle BR1 (Figure 4.21a) showed a significant decrease in $R_{e}$ occurring above the constructed redd. What is interesting is that this change in Reynolds conditions above the BR1 redd is unobservable from a velocity (Figure 4.17a) or a Froude number (Figure 4.19a) perspective. One explanation is that the BR1 measurements occurred on two separate days where profiles measured over the complete redd and above the attempted redd directly to the west were measured a day before the remaining profiles. Whiteman's Creek discharge decreased between the dates November 6 and November 5, 2006 from $6.4 \mathrm{~m}^{3} / \mathrm{s}$ to $5.3 \mathrm{~m}^{3} / \mathrm{s}$. Another possibility is that the redd form itself caused the reduction in $R_{e}$. BR2 shows that the two (relatively large) redds are situated with pockets of low $R_{e}$. Whereas, RR1 and RR3 redd placement seemingly avoided areas of high $R_{e}$ altogether.

Mean turbulent kinetic energy per unit area of streambed is the most revealing hydraulic metric to characterize areas surrounding chosen redd sites (Figures 4.23 and 4.24). It is clear that the brown and rainbow trout sought areas with reduced turbulence, not only in areas surrounding their redds, but in areas that appeared to be abandoned after initial cutting attempts, where redd abandonment is then presumed to be caused by unsuitable sediment conditions, species behaviour, etc. As expected, areas of high turbulent kinetic energy coincided with areas with large objects or bank restrictions disturbing the channels flow. For example, BR1 and RR1 demonstrated high turbulence associated with the form of the left bank, and BR2 and RR3 exhibited locally high turbulent kinetic energy from the presence of large objects obstructing the flow: e.g., a leaning tree rooted into a failing bank (BR2-Figure 4.23b); and a large boulder situated mid-riffle (RR3-Figure 4.24b).

Like Froude number to velocity, the distribution of bed shear is similar to that of turbulent kinetic energy, presumably because there is a reduction in radial shear stress $\left(\tau_{r}\right)$ that exists in the presence of secondary flow. Thus, similar to turbulent kinetic energy, redds were constructed (and attempted) in areas of reduced bed shear. With the exception of RR1, bed shear tended to reduce in the presence of the tailspill, which, hypothetically, is beneficial to preserving the redd form. The values of bed shear collected in this study are a direct measurement of boundarylayer flow.

Flow, even at the local scale, exhibits notable heterogeneity between individual measurements, consistent with Emery et al. [2003]. High degrees of heterogeneity must be acknowledged and accepted when assessing physical habitat using local metrics. To illustrate this further, composite habitat suitability indices were calculated using the geometric mean method (Equation 2.10). For spawning brown and rainbow trout, suitability factors were determined according to Figure 2.4 for velocity, depth, and temperature for each vertical velocity profile, and the mean particle size determined at each study riffle. The four suitability factors calculated 
for every vertical profile were then combined into a composite suitability index and is illustrated in Figures 4.27 and 4.28.

Figures 4.27 and 4.28 illustrates the composite suitability index determined from the collected data applied in a planform fashion. Notice the same degree of variation these reach-scale indices demonstrate when applied to local-scale measurements. These figures reveal that during a given day of local physical habitat sampling, the use of habitat suitability curves applied using local-scale metrics could vary widely over small spatial distances. There also appeared to be no correlation with local-scale composite suitability indices and redd-site selection; whereas, from the HEC-RAS ${ }^{\circledR}$ analysis, a larger reach-scale perspective, high composite suitability values did, in fact, coincide with most spawning locations.

It must be stressed that these habitat suitability curves developed for the Instream Flow Incremental Methodology (IFIM-Bovee, 1982; Stalnaker et al., 1995) were intended for reach-scale habitat suitability assessment; therefore this author, in agreement with Lamouroux and Souchon [2002] and Souchon and Capra [2004], questions the applicability of HSI coupled with multi-dimensional hydraulic models. Of all the metrics tested, HSI/WUA (i.e., habitat suitability models) showed the least correlation to redd-site preference at the local-scale, even though the models did predict spawning locations at the reach-scale. In addition, and of concern, high composite suitability values at times occurred where turbulent kinetic energy and bed shear were at their highest. Perhaps, at the time of spawning, when flow conditions were undoubtedly different, these composite suitability plots would have appeared quite differently. Presumably then, if averaged across each study riffle, composite suitability values would yield important information with regards to spawning behaviour; nevertheless, this implies that HSI must be restricted to reach-scale assessments, as originally intended. 


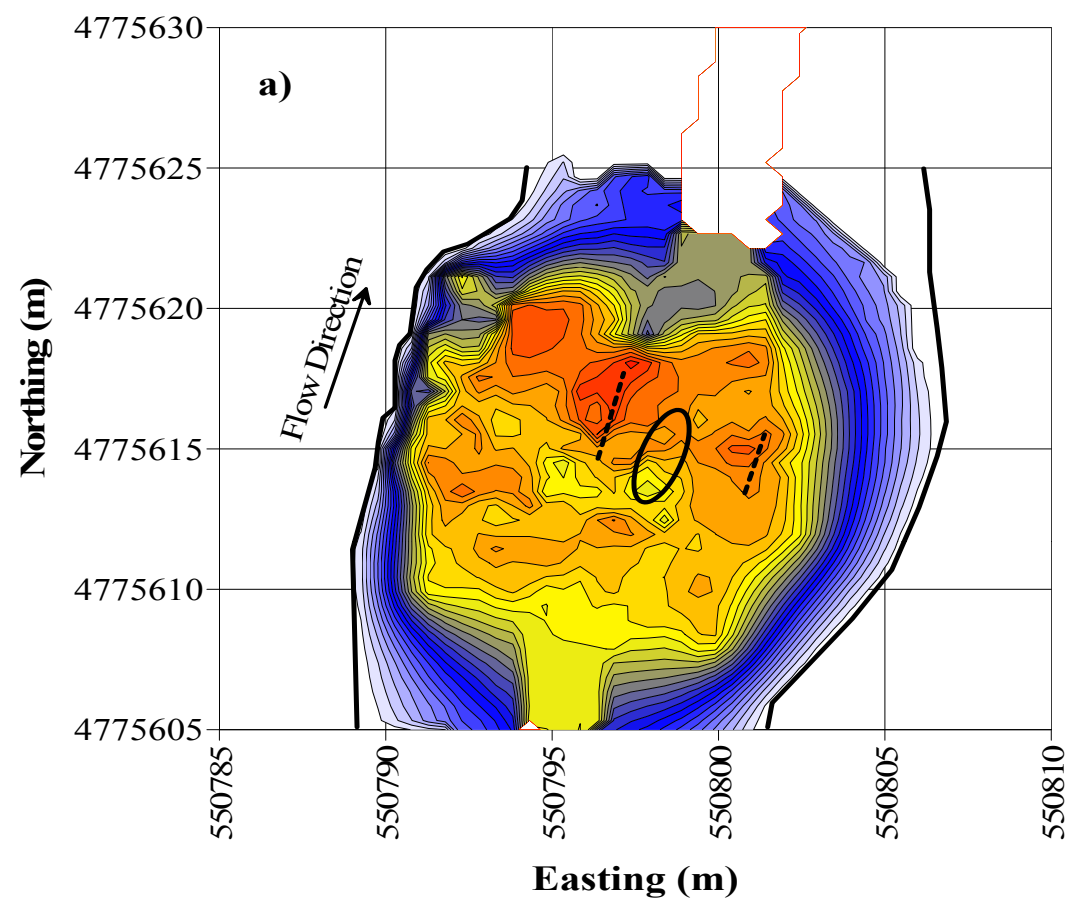

Legend:

$\mathrm{U}(\mathrm{cm} / \mathrm{s})$
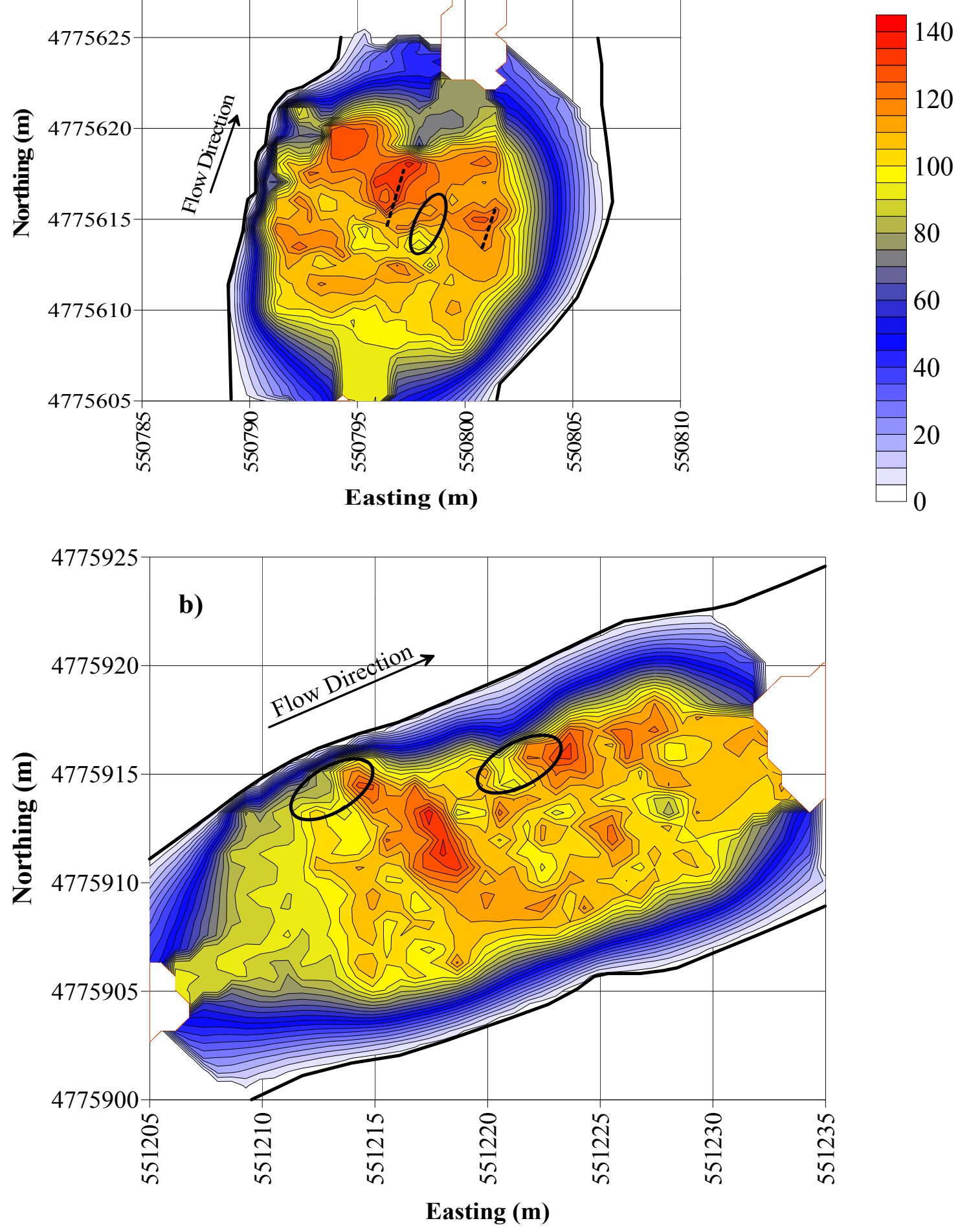

Figure 4.17: Mean profile velocity surrounding brown trout redds at $Q \approx 5.55 \mathrm{~m}^{3} / \mathrm{s}$. a) Riffle 1 and b) Riffle 2. Ellipse(s) - redd (pit and tailspill) location(s); Dashed lines-Abandoned redd construction. 


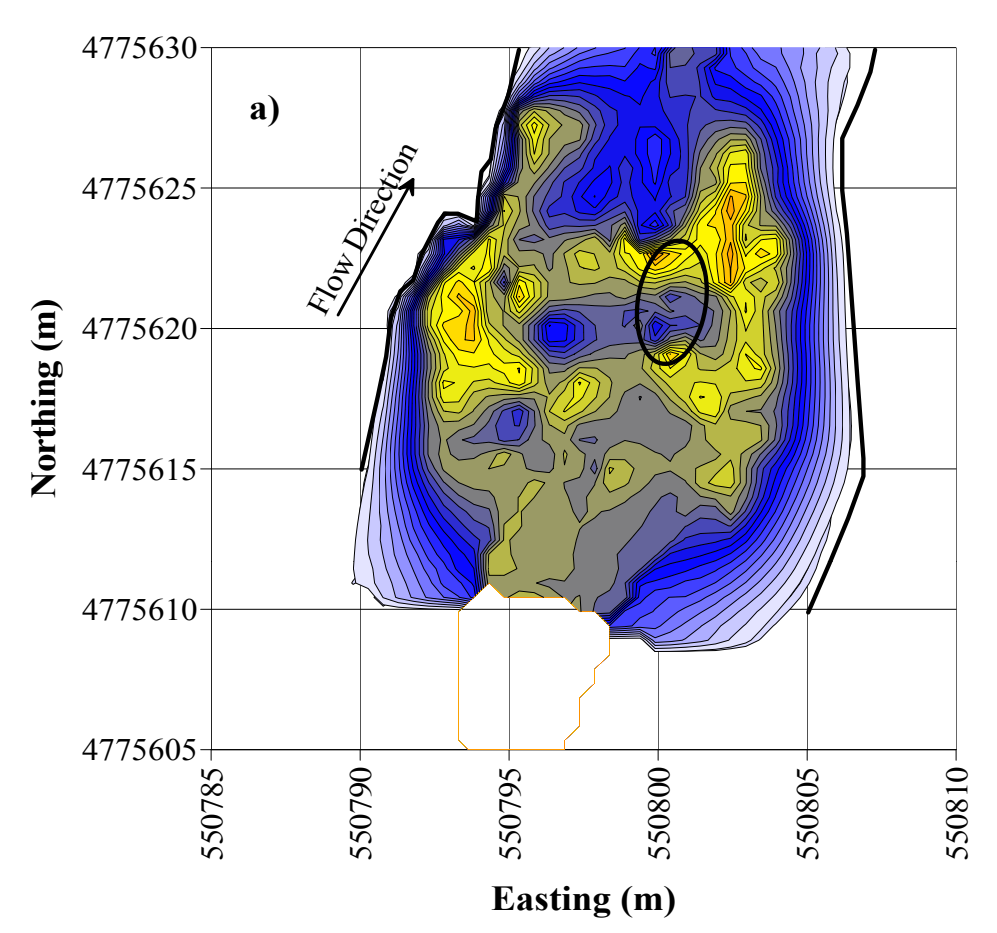

Legend:

$\mathrm{U}(\mathrm{cm} / \mathrm{s})$
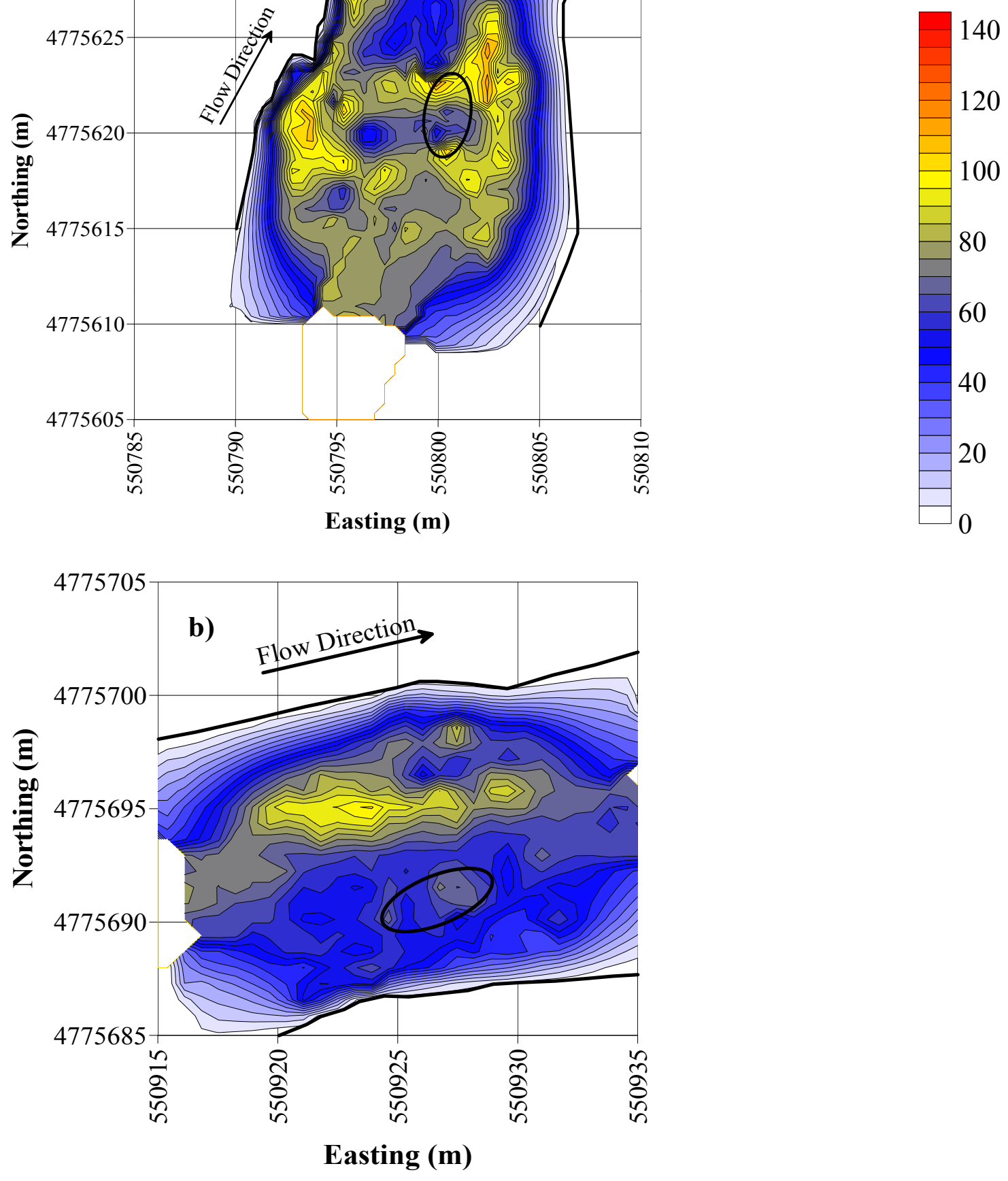

Figure 4.18: Mean profile velocity surrounding rainbow trout redds at $Q \approx$ $2.33 \mathrm{~m}^{3} / \mathrm{s}$. a) Riffle 1 and b) Riffle 3. Ellipse - redd (pit and tailspill) location. 


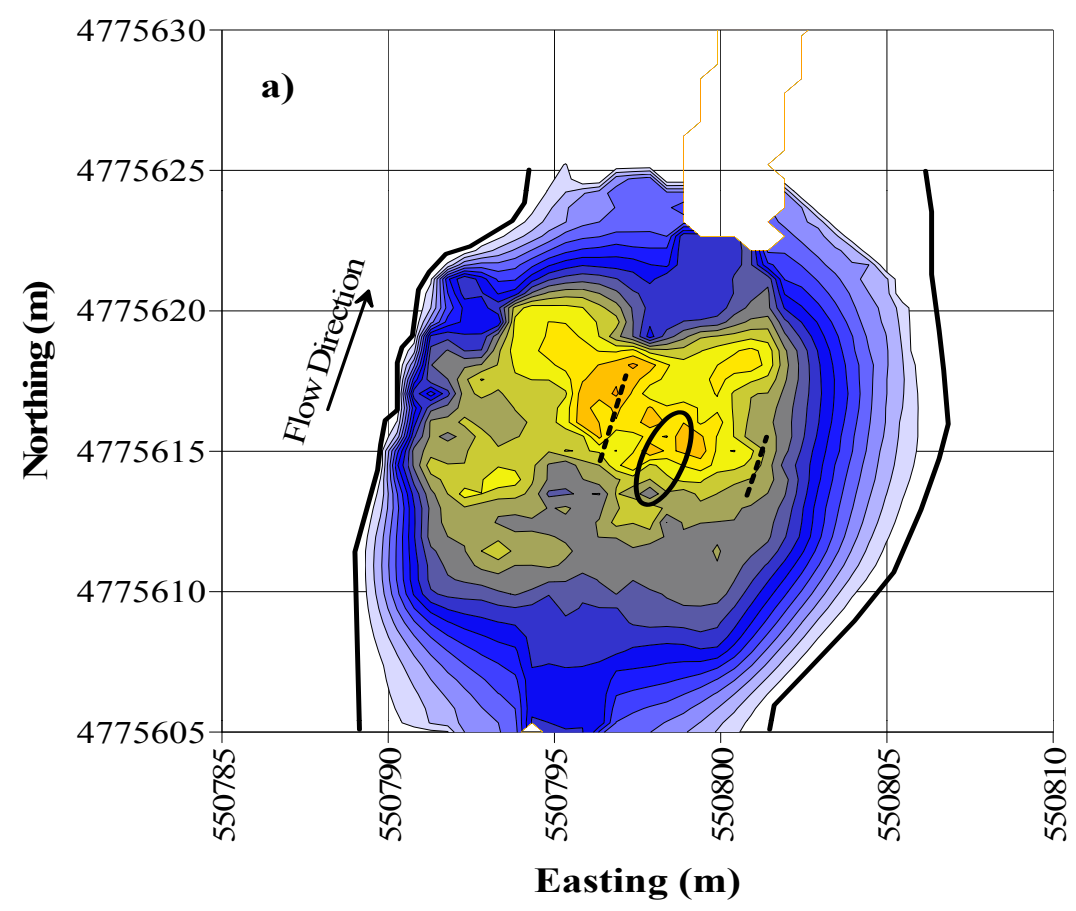

Legend:

Froude number (-)
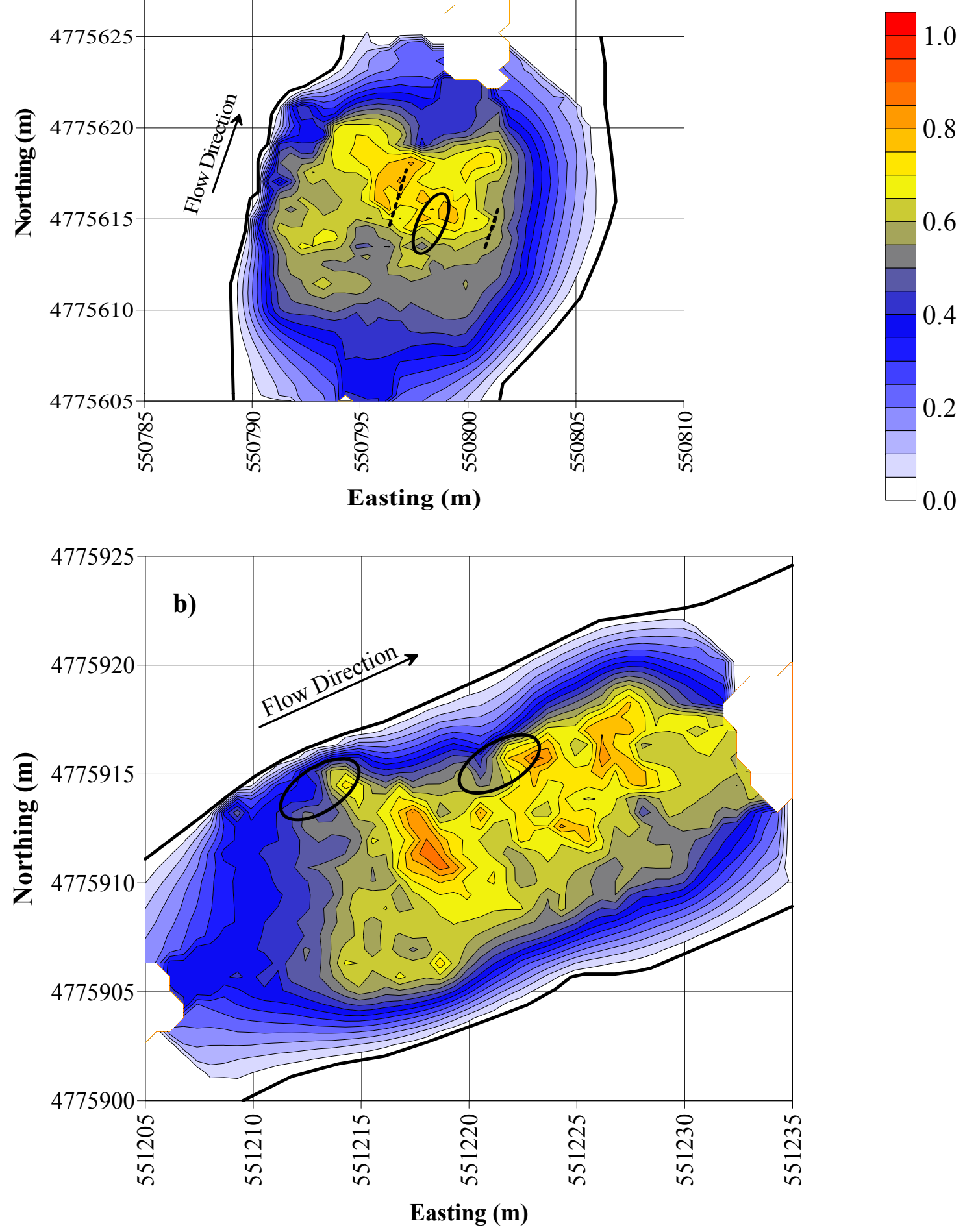

Figure 4.19: Froude number surrounding brown trout redds at $Q \approx 5.55 \mathrm{~m}^{3} / \mathrm{s}$. a) Riffle 1 and b) Riffle 2. Ellipse(s) — redd (pit and tailspill) location(s); Dashed lines-Abandoned redd construction. 
Legend:

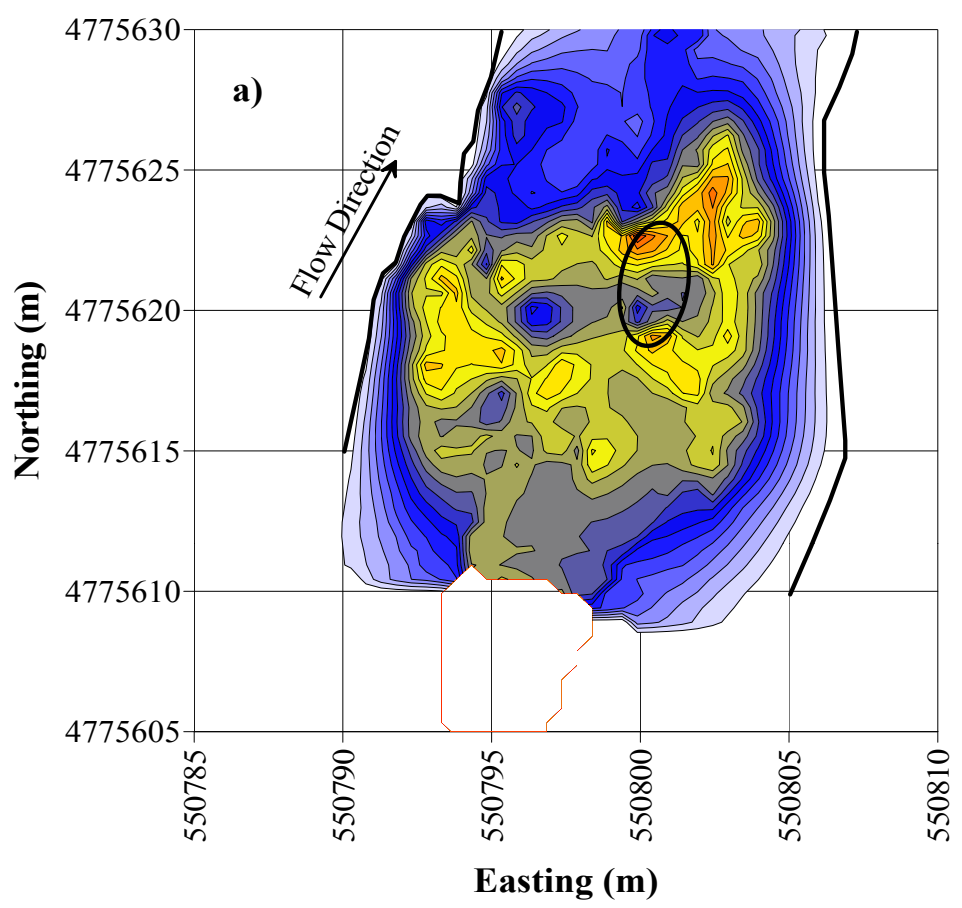

Froude number $(-)$
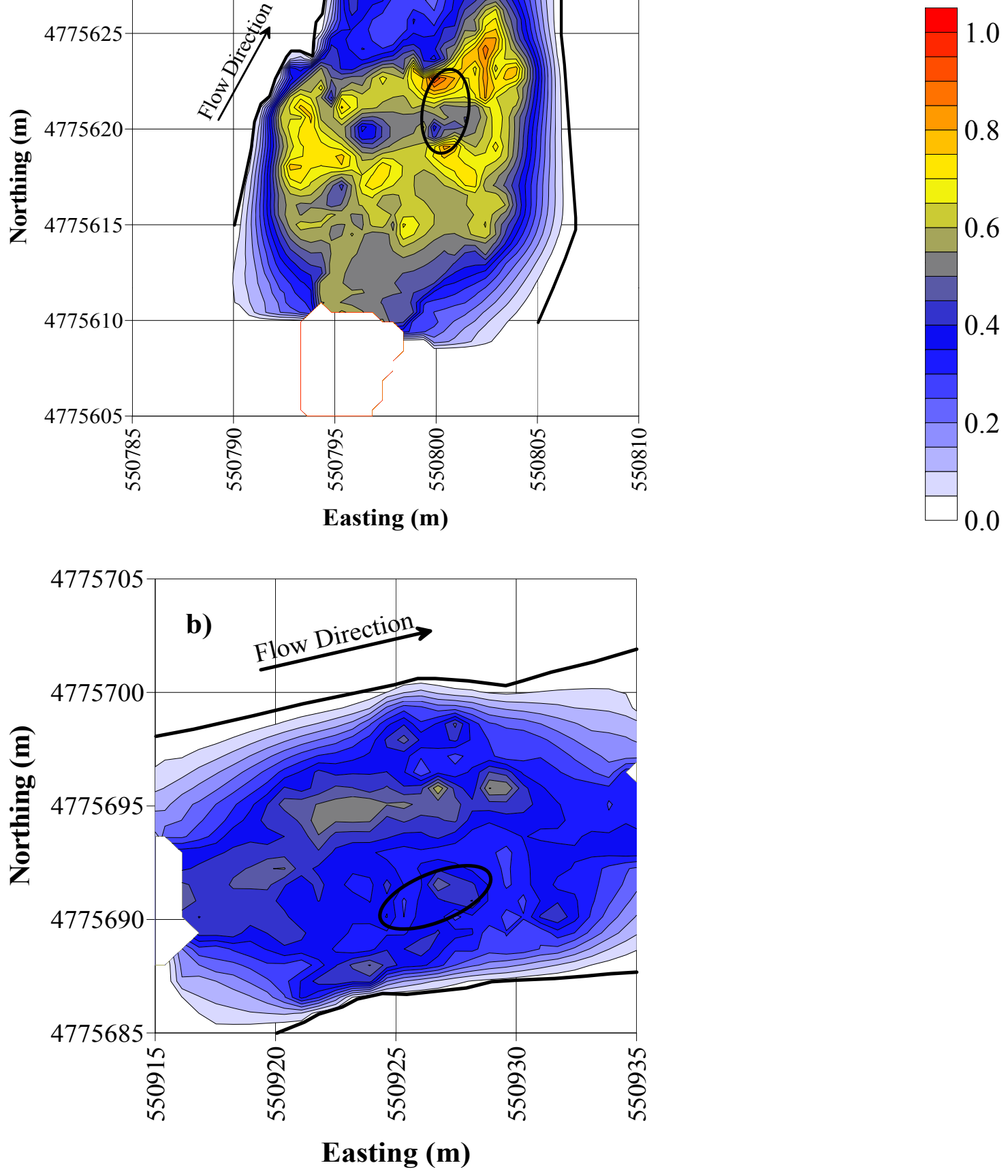

Figure 4.20: Froude number surrounding rainbow trout redds at $Q \approx 2.33 \mathrm{~m}^{3} / \mathrm{s}$. a) Riffle 1 and b) Riffle 3. Ellipse - redd (pit and tailspill) location. 


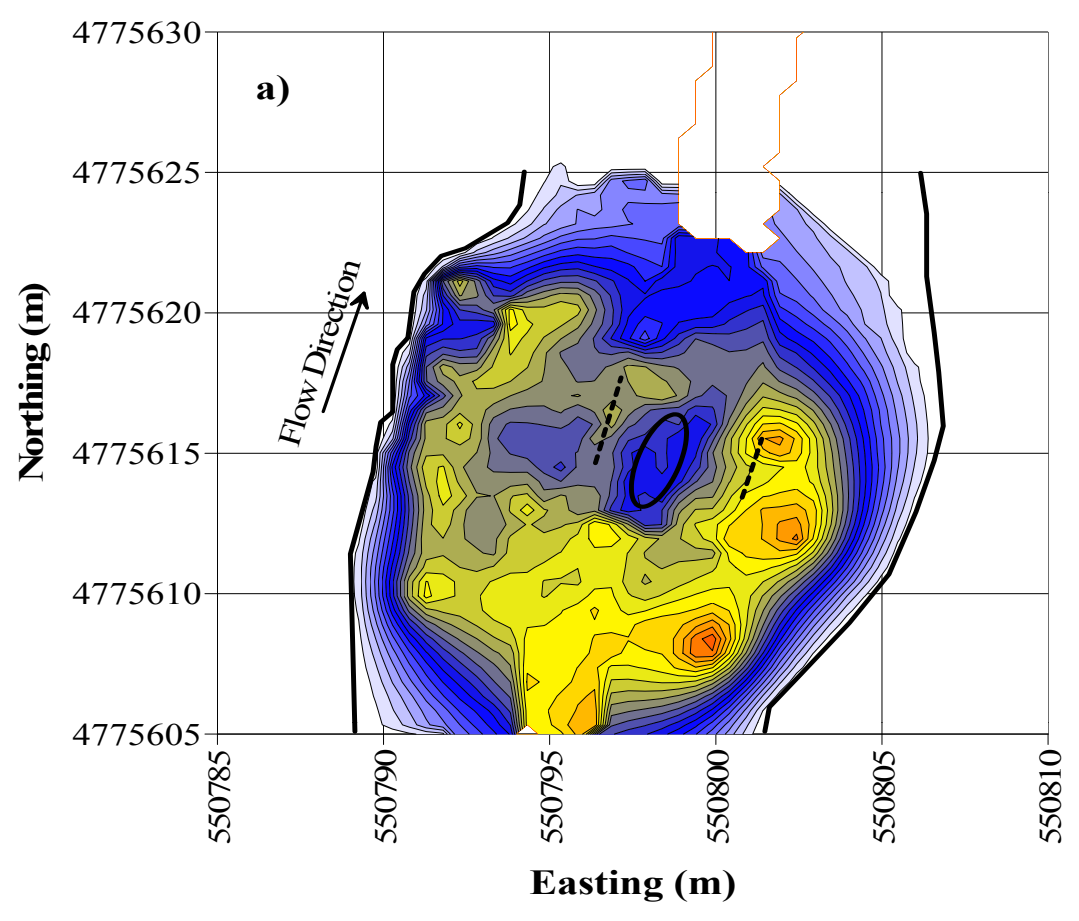

Legend:

Reynolds number (-)

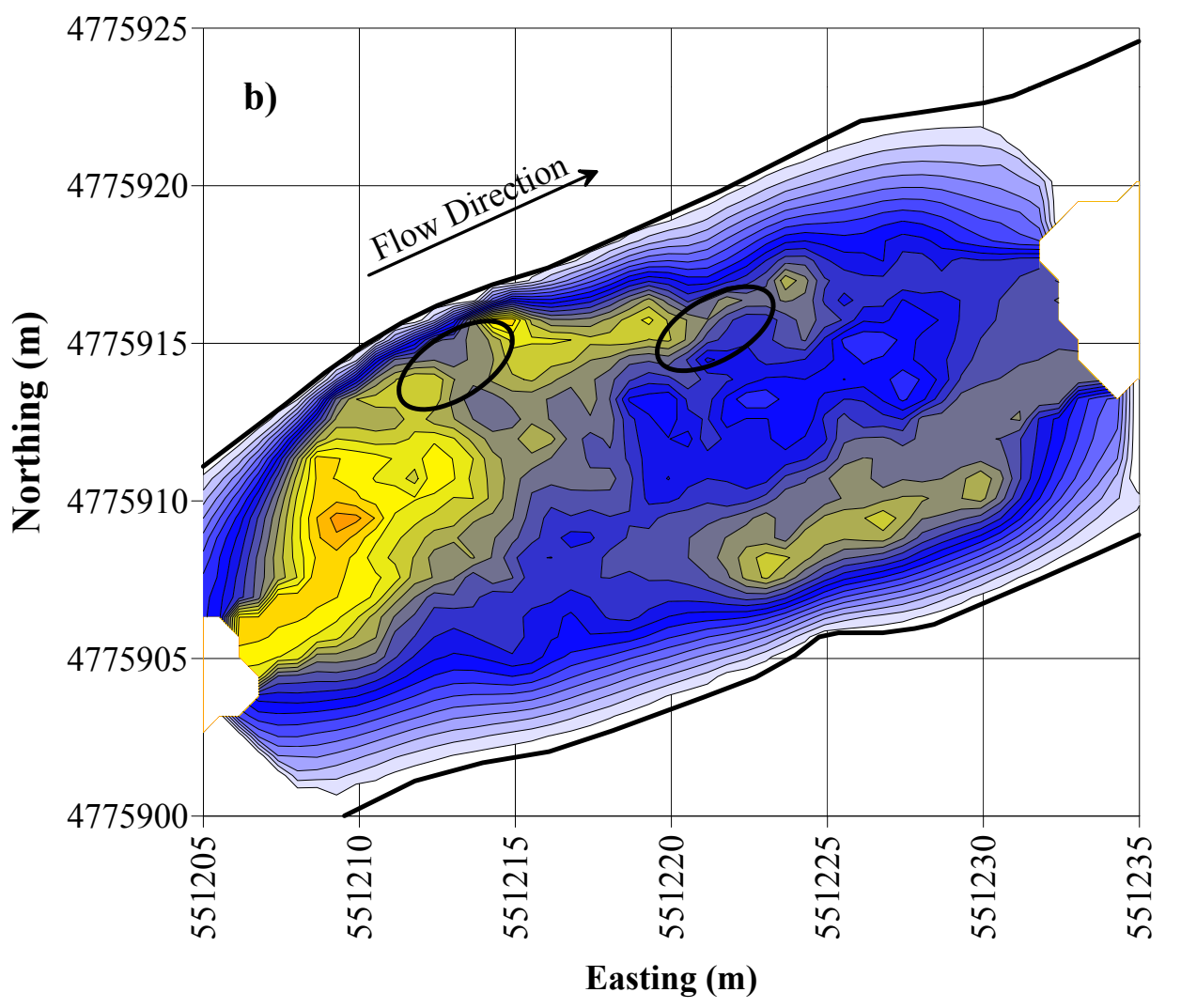

Figure 4.21: Reynolds number surrounding brown trout redds at $Q \approx 5.55 \mathrm{~m}^{3} / \mathrm{s}$. a) Riffle 1 and b) Riffle 2. Ellipse(s) - redd (pit and tailspill) location(s); Dashed lines-Abandoned redd construction. 
Legend:

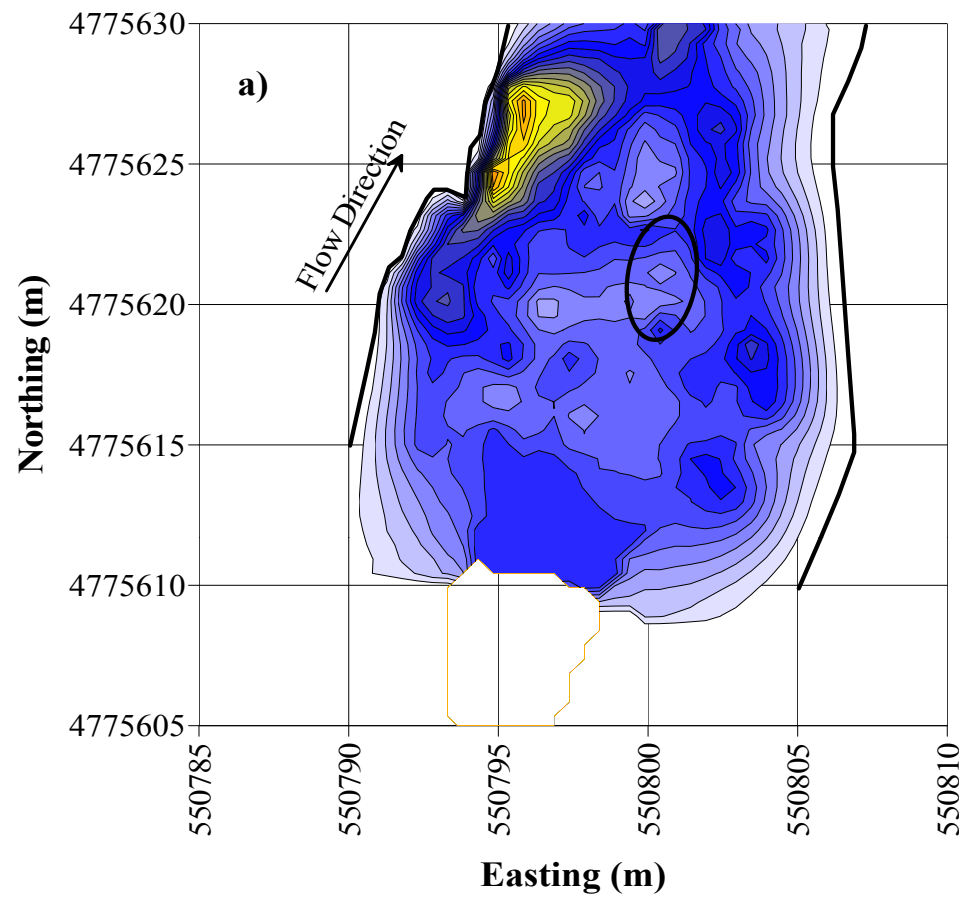

Reynolds number (-)
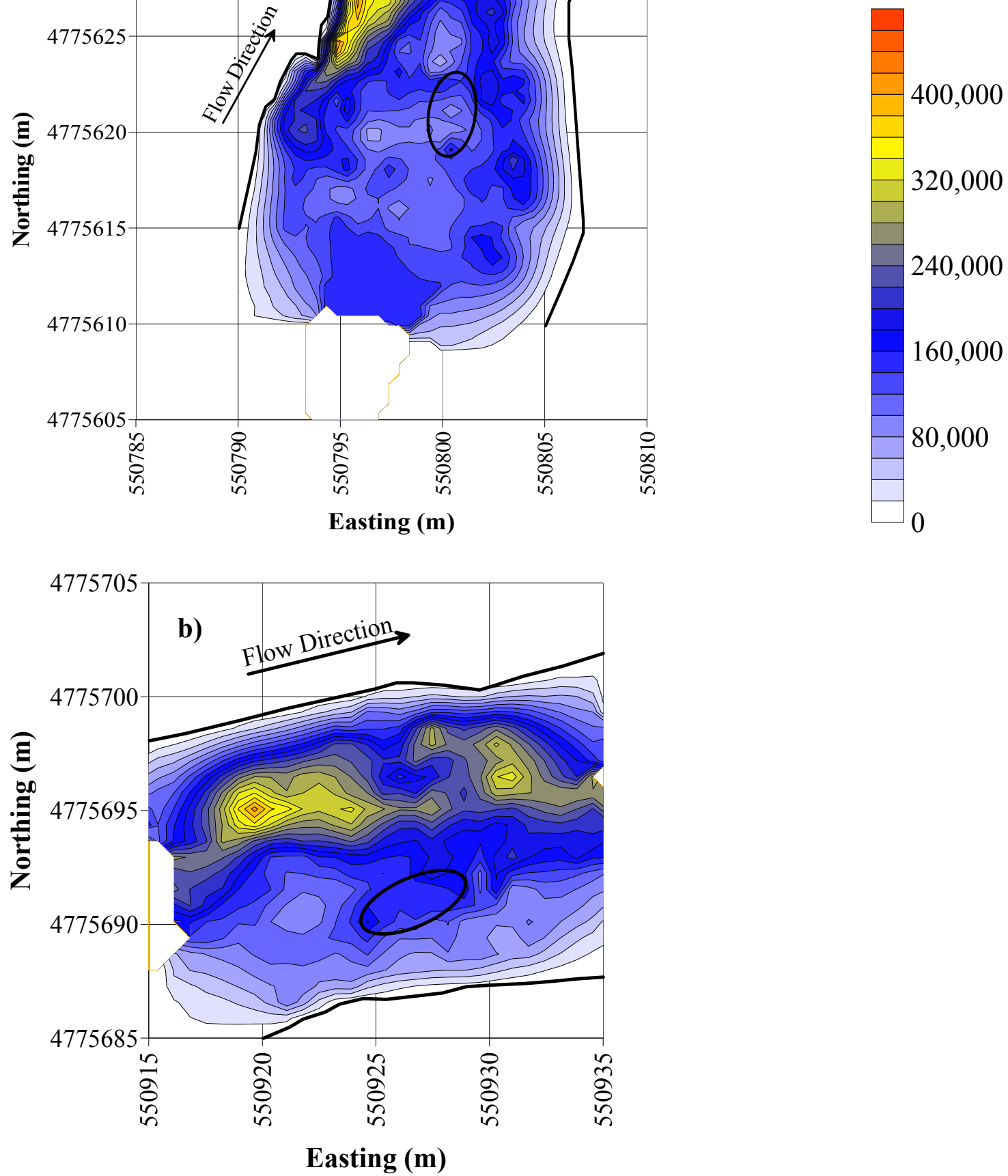

Figure 4.22: Reynolds number surrounding rainbow trout redds at $Q \approx 2.33 \mathrm{~m}^{3} / \mathrm{s}$. a) Riffle 1 and b) Riffle 3. Ellipse - redd (pit and tailspill) location. 


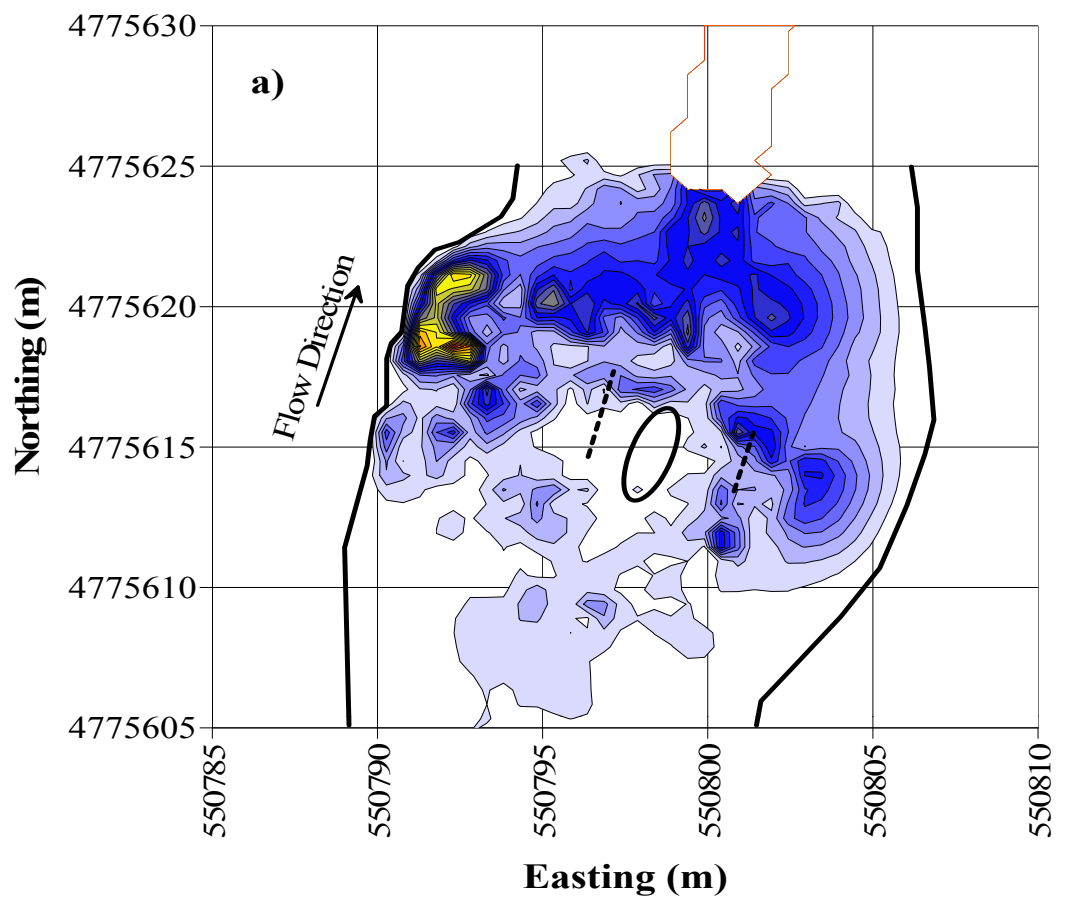

Legend:

$\bar{e}_{a}\left(J / m^{2}\right)$
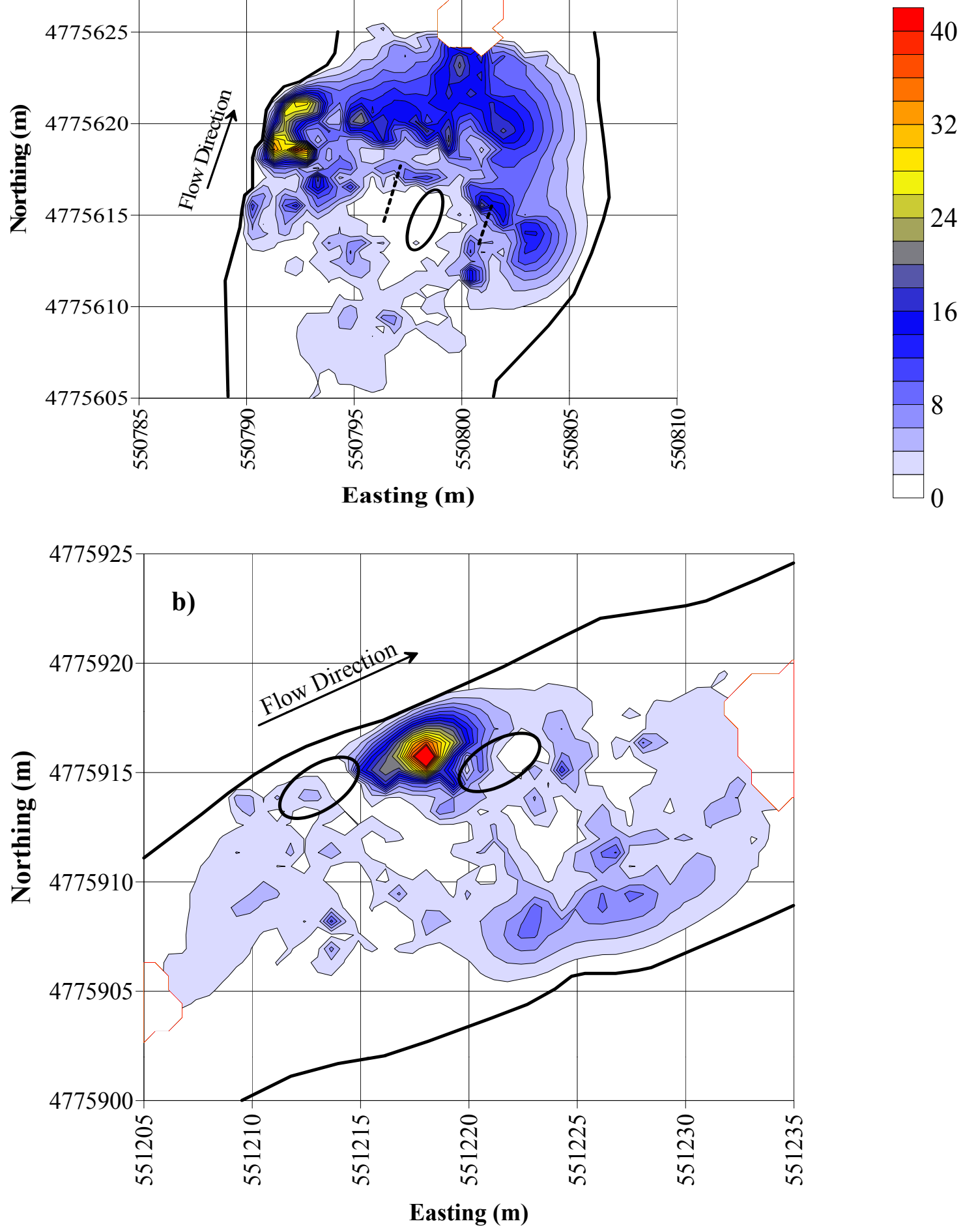

Figure 4.23: Turbulent kinetic energy per unit area surrounding brown trout redds at $Q \approx 5.55 \mathrm{~m}^{3} / \mathrm{s}$. a) Riffle 1 and b) Riffle 2. Ellipse(s)—redd (pit and tailspill) location(s); Dashed lines-Abandoned redd construction. 

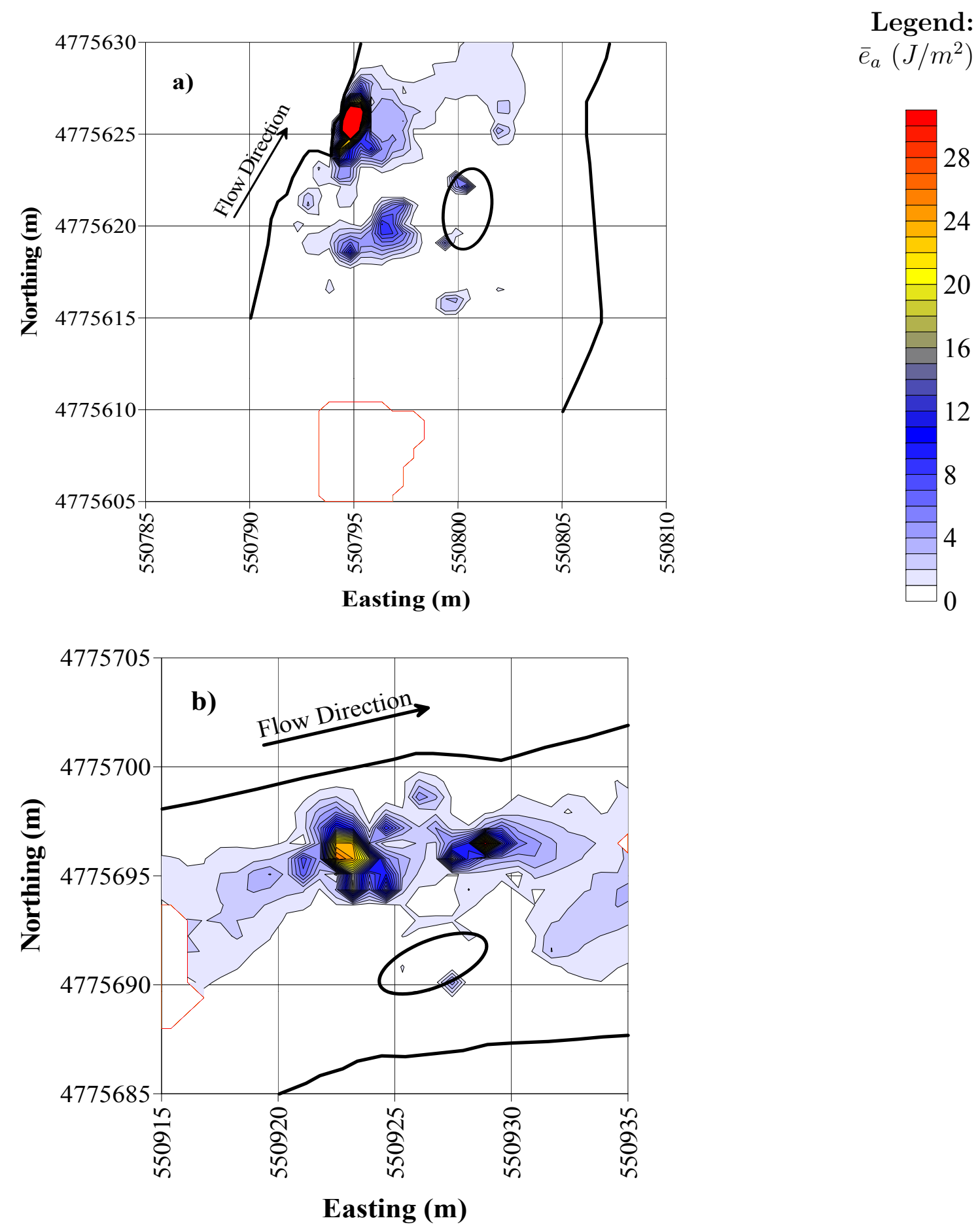

Figure 4.24: Turbulent kinetic energy per unit area surrounding rainbow trout redds at $Q \approx 2.33 \mathrm{~m}^{3} / \mathrm{s}$. a) Riffle 1 and b) Riffle 3. Ellipse -redd (pit and tailspill) location. 


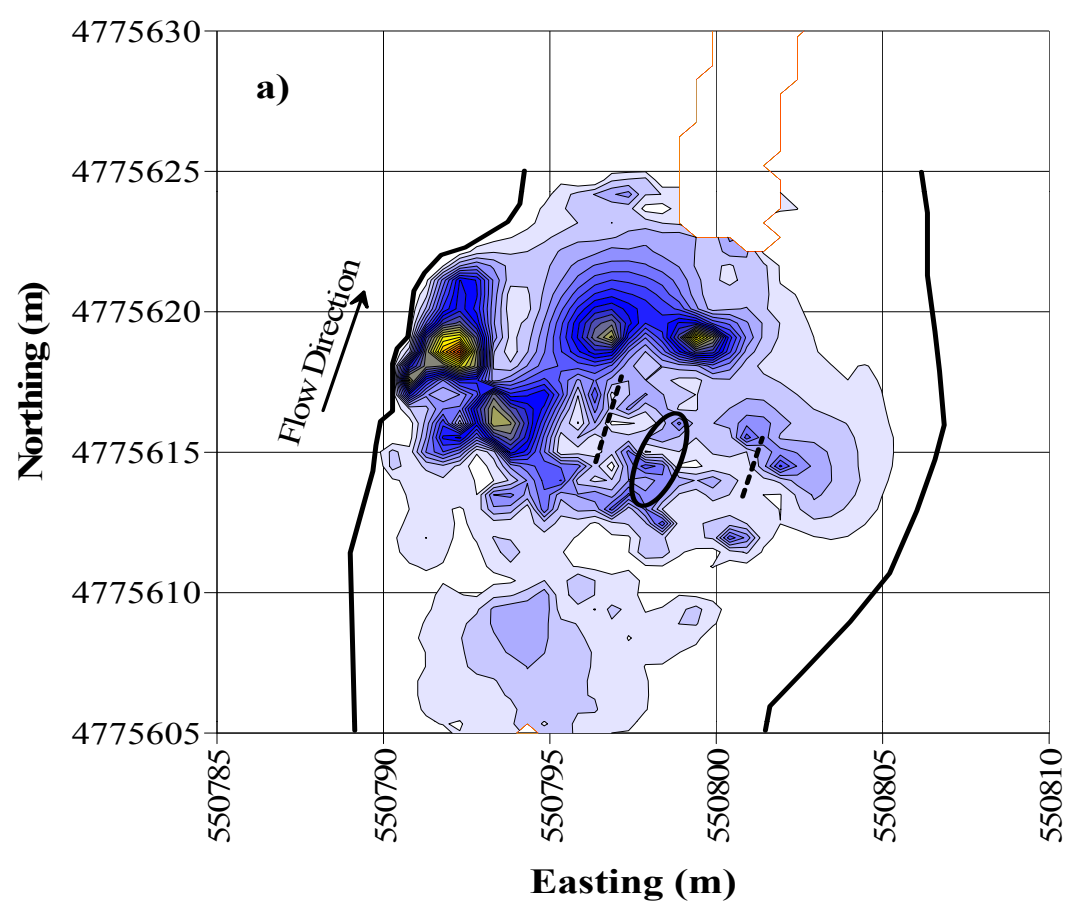

Legend:

Bed shear $\left(N / m^{2}\right)$

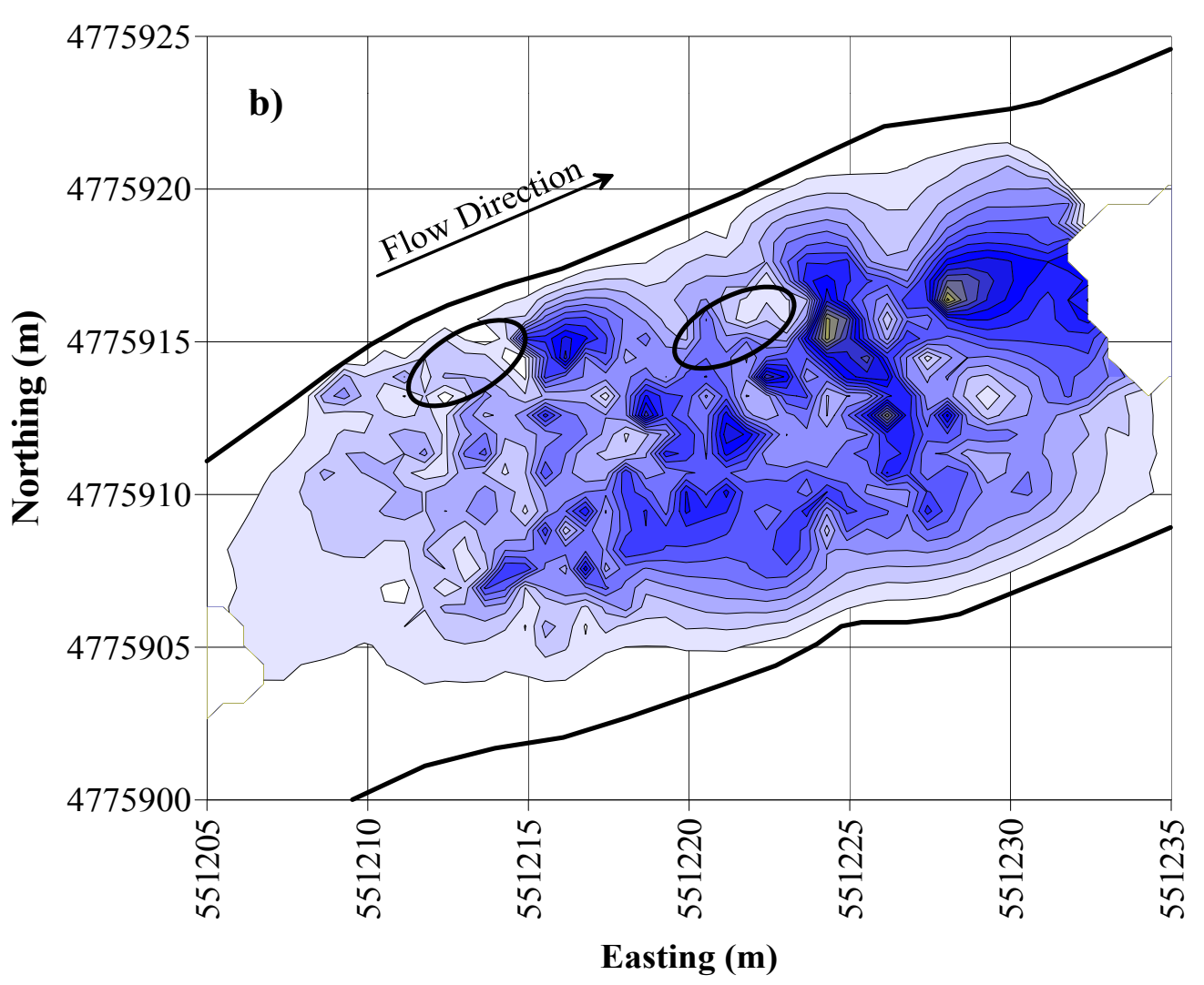

Figure 4.25: Bed shear surrounding brown trout redds at $Q \approx 5.55 \mathrm{~m}^{3} / \mathrm{s}$. a) Riffle 1 and b) Riffle 2. Ellipse(s) - redd (pit and tailspill) location(s); Dashed linesAbandoned redd construction. 
Legend:

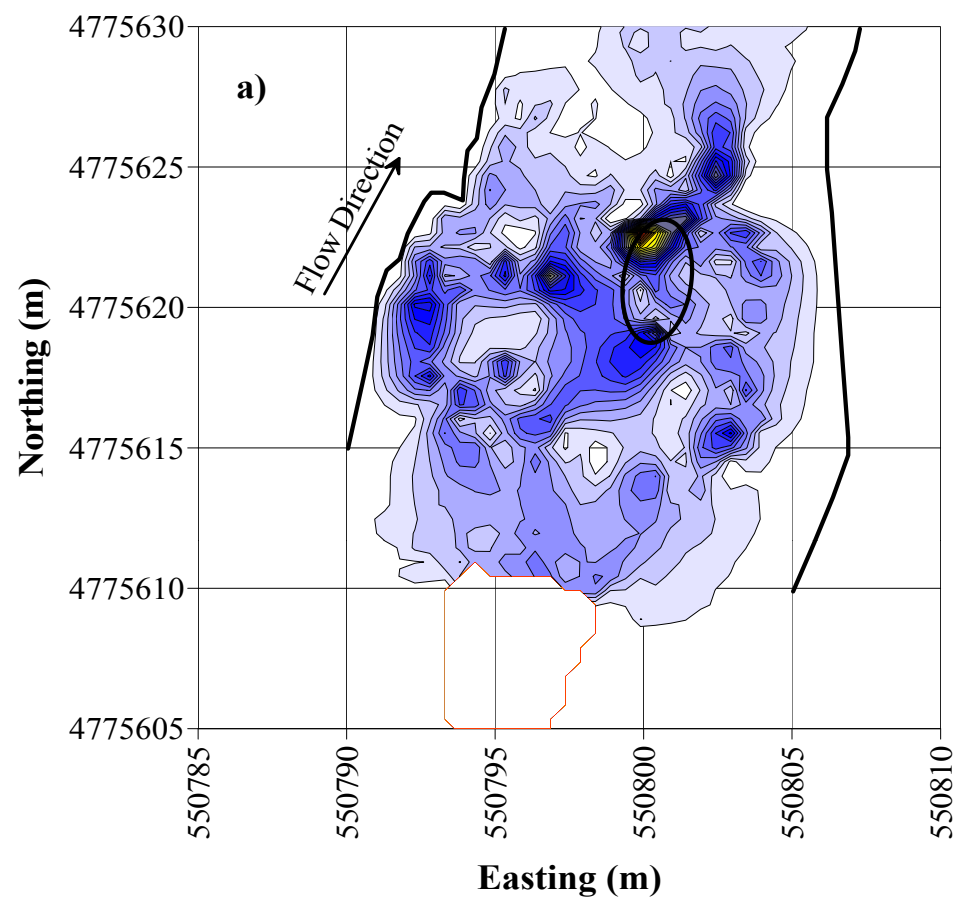

Bed shear $\left(N / m^{2}\right)$
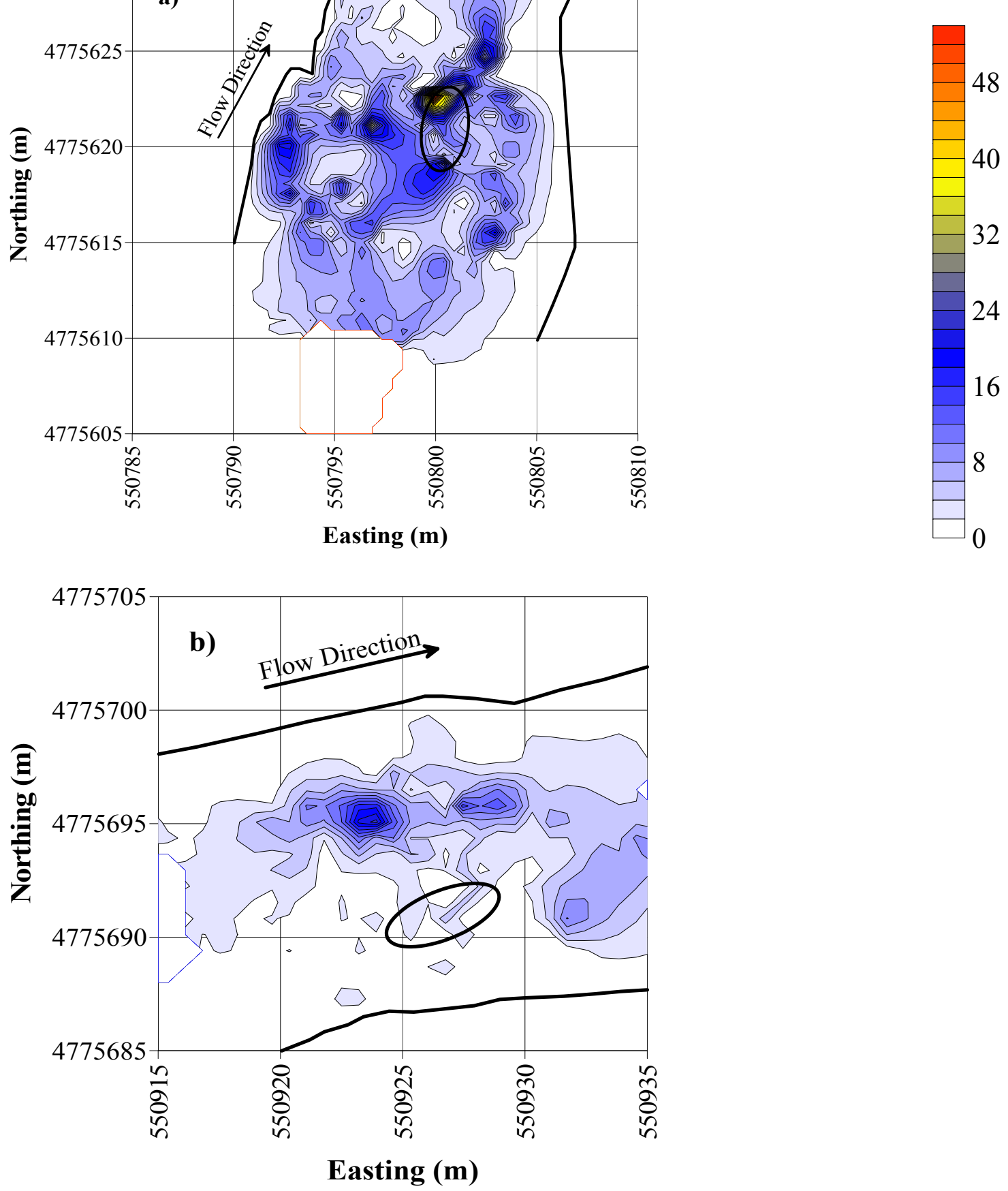

Figure 4.26: Bed shear surrounding rainbow trout redds at $Q \approx 2.33 \mathrm{~m}^{3} / \mathrm{s}$. a) Riffle 1 and b) Riffle 3. Ellipse - redd (pit and tailspill) location. 


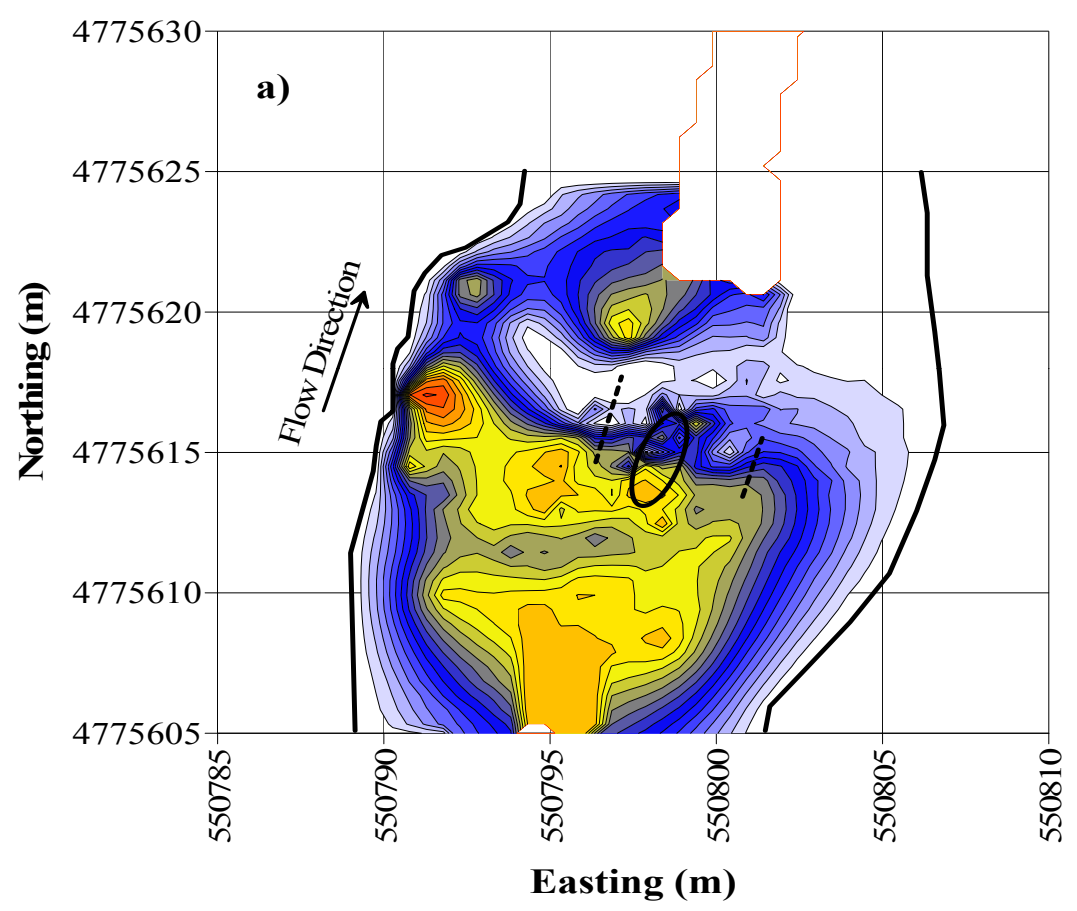

Legend:

$C_{i}(-)$
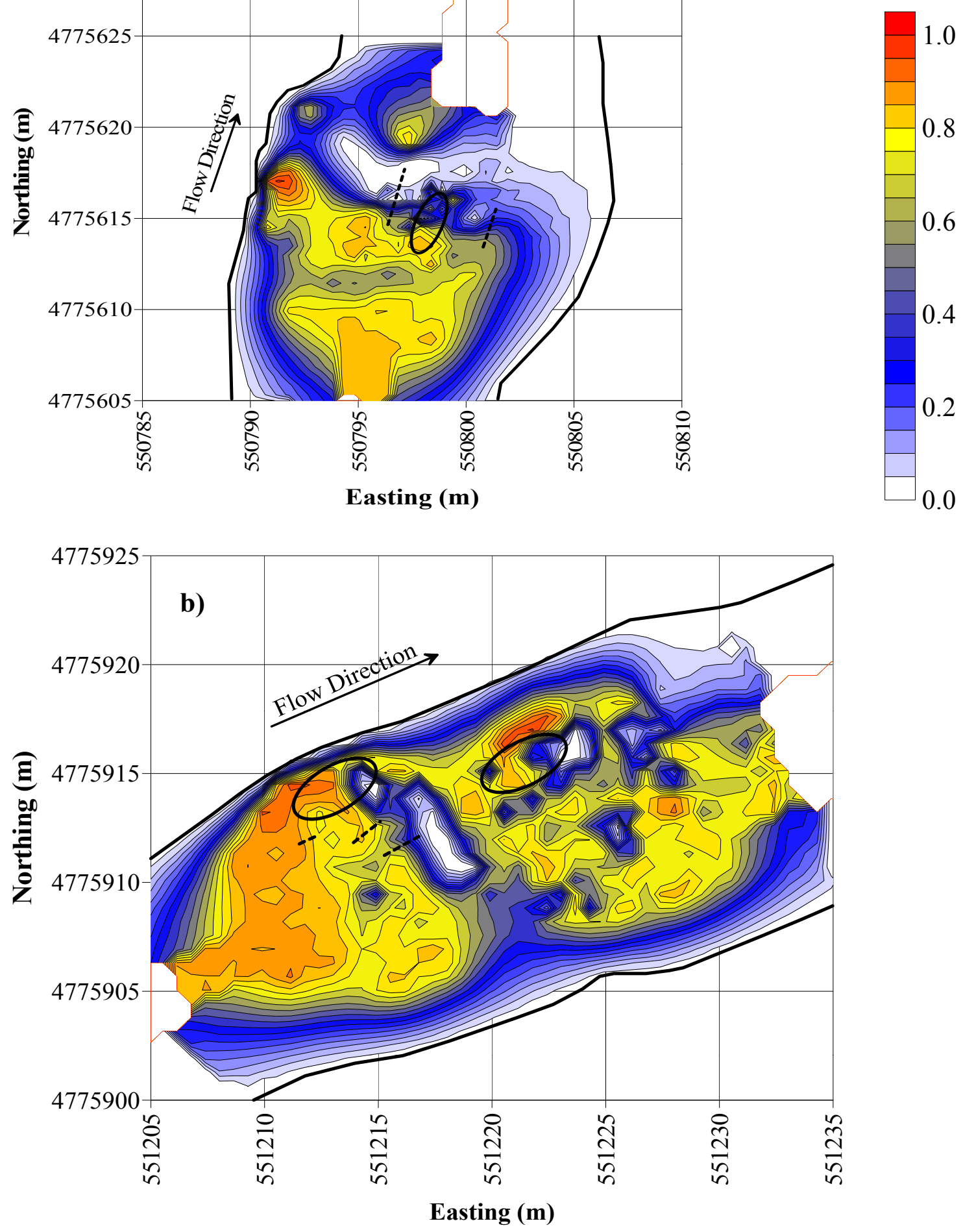

Figure 4.27: Composite suitability index surrounding brown trout redds at $Q \approx$ $5.55 \mathrm{~m}^{3} / \mathrm{s}$. a) Riffle 1 and b) Riffle 2. Ellipse(s) — redd (pit and tailspill) location(s); Dashed lines-Abandoned redd construction. 

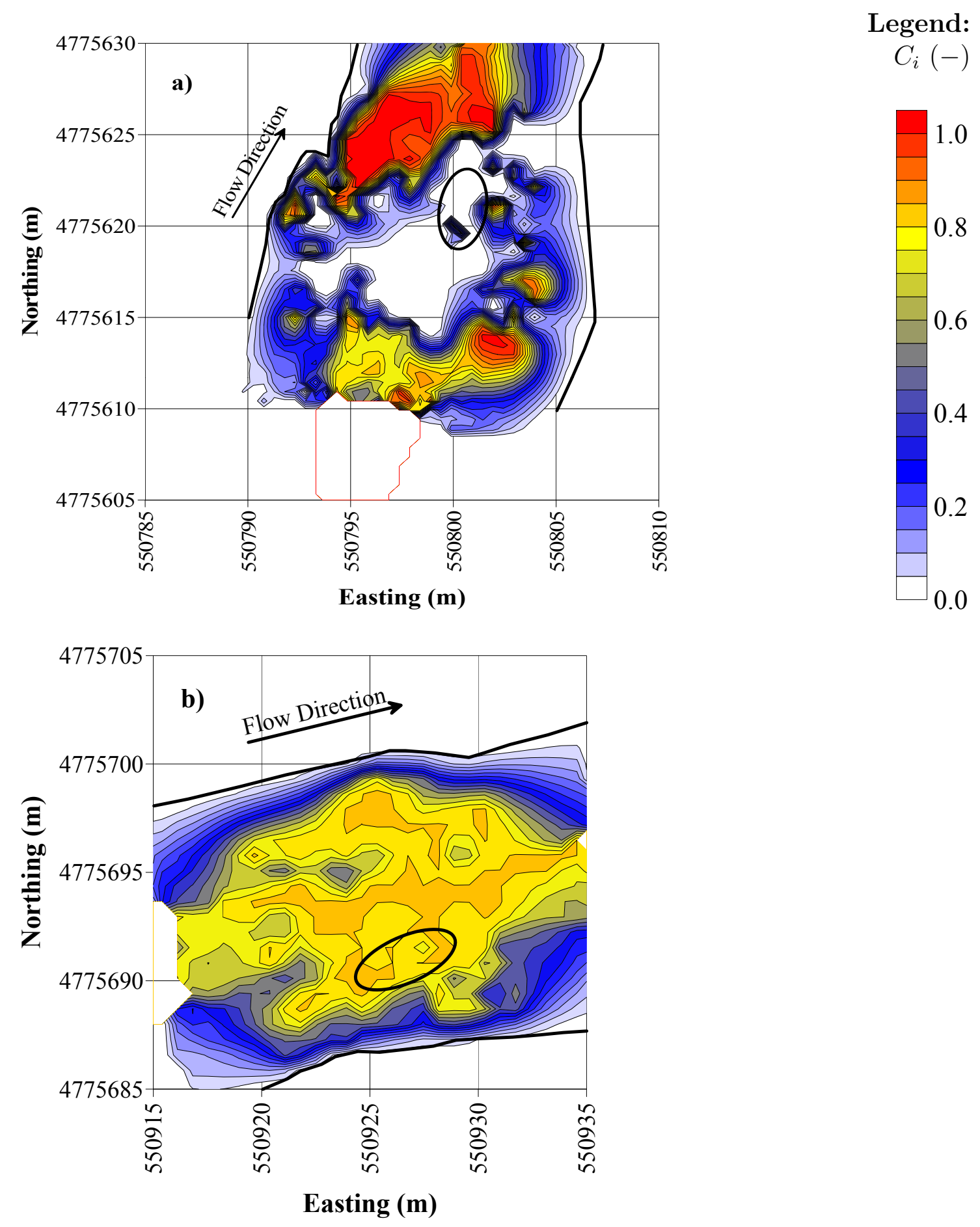

Figure 4.28: Composite suitability index surrounding rainbow trout redds at $Q \approx$ $2.33 \mathrm{~m}^{3} / \mathrm{s}$. a) Riffle 1 and b) Riffle 3. Ellipse - redd (pit and tailspill) location. 


\section{Chapter 5}

\section{Conclusions}

A high-resolution investigation studying the hydrodynamic characteristics of redds and surrounding habitat has been undertaken in attempts to identify physical metrics, at varying scales, that relate physical habitat to redd-site selection. Metrics of velocity, Reynolds number, Froude number, bed shear, turbulent kinetic energy, and depth were used to quantify the hydraulic characteristics at the various scales. Results show that there is tremendous spatial variability in all metrics and that the only parameter that consistently demonstrated any spatial correlation with the location of redds was turbulent kinetic energy per unit area of stream bed. Turbulent kinetic energy per unit area never exceeded $15 \mathrm{~J} / \mathrm{m}^{2}$ in close proximity to redds whereas values typically ranged between $1 \mathrm{~J} / \mathrm{m}^{2}<\bar{e}_{a}<50 \mathrm{~J} / \mathrm{m}^{2}$ elsewhere on the riffles. The low turbulent kinetic energy per unit area is related to flow regimes where little turbulence is present and flow is essentially unidirectional.

At the redd-scale, the lowest turbulent kinetic energy per unit area existed atop the tailspills, where the flow passing over the elongated teardrop form showed an increase in the linearity of flow. From a fluid dynamics perspective, the teardrop form is known to produce the lowest amount of drag per unit volume, as long as the fluid flow is moving along the teardrop's principal axis (Vogel, 1994). Low turbulent kinetic energy per unit area also existed in areas of close proximity to the identified redds and at locations where redd-construction commenced, yet, for reasons unknown, was later abandoned.

At the riffle-scale, the metrics used to quantify the fluid properties varied widely, often with a relative error close to unity. At low-flow wading conditions, the heterogeneity of riffle hydraulics is evident, and its spatial distribution varies over short distances $(<1 \mathrm{~m})$. For example, the riffles measured frequently observed up to 40 $\mathrm{cm} / \mathrm{s}$ variations in velocity within a $1 \mathrm{~m}$ planometric discretization. This variability, however, was not specific to any particular channel feature (e.g., increased velocity did not necessarily coincide with the location of the thalweg); instead, the variability appeared to be randomly distributed, both laterally and longitudinally across each study riffle.

A preliminary weighted usable area assessment for the entire $3 \mathrm{~km}$ study reach 
was performed to quantify the overall habitat quality for spawning rainbow trout and brown trout. Discharges deemed optimal for the spawning fishes coincided quite well with the discharges that occurred when redd construction was initiated. However, there is question as to whether the weighted useable area results actually reflect the safe/wading conditions present during the collection of data used to create the habitat suitability indices, perhaps generating a spurious result. Habitat suitability indices used in developing the reach-scale weighted usable area analysis were applied at riffle-scale resolution similar to two-dimensional hydraulic models. Habitat suitability indices at this scale showed the same degree of spatial variation and did not indicate likely redd locations. It should be noted that habitat suitability indices were initially intended to be used as a reach-scale metric (USGS, 2001) and the results of this thesis suggest that they should remain so.

Two notable limitations existed in this study which merit future research. The first relates to the flow conditions within which measurements were taken. All measurements were acquired in flows that were limited by safe wading conditions. Based upon the one-dimensional modelling that was conducted, velocities, bed shear, and the other hydraulic metrics will continue to increase with increasing discharge. As the discharge increases to thresholds that begin to impact channel form, the changes in flow regime should also impact the redds. High resolution measurements under these flow regimes would significantly contribute to furthering the fluid mechanics linkages between the aquatic habitat conditions and channel form over a wide range in flow regimes.

The second notable limitation in this work was in the a priori measurement of redds assuming that there is a direct correlation between fluid characteristics and redd-site selection preferences. The locations where redds were constructed and measured were not measured prior to redd selection and construction. Only locations with evidence of abandoned redd construction which were measured were the closest to the pre-construction conditions. To further develop linkages between redd-site selection and any relevant hydraulic parameters, studies should be conducted which measure the hydrodynamic properties of the channel pre- and postredd construction. Such studies may then identify any relevant properties which can further link the hydrodynamic properties of running waters to redd-site selection. 


\section{References}

ALLEN, J.D., 1995, Stream Ecology: Structure and Function of Running Waters, Springer.

ANNABLE, W.K., 1996, Database of morphologic characteristics of watercourses in Southern Ontario, Ontario Ministry of Natural Resources, 212 pp.

ANNEAR T., I. CHISHOLM, H. BEECHER, A. LOCKE, AND 12 OTHER AUTHORS, 2004, Instream Flows for Riverine Resource Stewardship, revised edition, Instream Flow Council, Cheyenne, WY.

ARCEMENT JR., G.J., V.R. SCHNEIDER, 1989, Guide for selecting Manning's roughness coefficients for natural channels and flood plains, U.S.G.S. Watersupply paper 2339, 44 pp.

BAGNOLD, R.A., 1980, An Empirical Correlation of Bedload Transport Rates in Flumes and Natural Rivers, Proceedings of the Royal Society of London. Series A, Mathematical and Physical Sciences, 372, pp. 453-473.

BAINBRIDGE, R., 1962, Training, speed and stamina in trout, Journal of Experimental Biology, 39, pp. 537-555.

BEARD JR., T.D., R.F. CARLINE, 1991, Influence of spawning and other stream habitat features on spatial variability of wild brown trout, Transactions of the American Fisheries Society, 120, pp. 711-722.

BERNIER-BOURGAULT, I., P. MAGNAN, 2002, Factors affecting redd site selection, hatching, and emergence of brook charr, Salvelinus fontinalis, in an artificially enhanced site, Environmental Biology of Fishes, 64, pp. 333-341.

BEVINGTON, P.R., D.K. ROBINSON, 1992, Data Reduction and Error Analysis for the Physical Sciences, 2nd ed. Boston; New York: McGraw-Hill.

BLANCHFIELD, P.J., M.S. RIDGWAY, 1996, Use of seepage meters to measure groundwater flow at brook trout redds, Transactions of the American Fisheries Society, 125, pp. 813-818. 
BLANCHFIELD, P.J., M.S. RIDGWAY, 1997, Reproductive timing and use of redd sites by lake-spawning brook trout (Salvelinus fontinalis), Canadian Journal of Fisheries and Aquatic Sciences, 54, pp. 747-756.

BONHAM, K., 1976, Specific gravity of salmon eggs, Transactions of the American Fisheries Society, 2, pp. 351-352.

BOVEE, K.D., 1982, A guide to stream habitat analysis using the instream flow incremental methodology, Instream Flow Information Paper 12. US Fish and Wildlife Service, 246 pp.

BRAY, D.I., 1980, Evaluation of effective boundary roughness for gravel-bed rivers, Canadian Journal of Civil Engineering, 7, pp. 392-397.

BRIGGS, J.C., 1953, The behaviour and reproduction of salmonid fishes in a small coastal stream, State Of California Department Of Fish And Game Marine Fisheries Branch, Fish Bulletin, 94, pp. 62.

BROWN, C.J.D., 1971, Fishes of Montana, Montana State University, Big Sky Books, Bozeman.

BUCHANAN, T.J., W.P. SOMERS, 1969, Discharge measurements at gaging stations, US Geological Survey Techniques of Water-Resources Investigation, book 3, chapter A8, 73 pp.

BUNN, S.E., A.H. ARTHINGTON, 2002, Basic principles and ecological consequences of altered flow regimes for aquatic biodiversity, Environmental Management, 30(4), pp. 492-507.

BUNTE, K., S.R. ABT, 2001, Sampling Surface and Subsurface Particle-Size Distributions in Wadable Gravel- and Cobble-Bed Streams for Analyses in Sediment Transport, Hydraulics, and Streambed Monitoring, United States Department of Agriculture Forest Service, Rocky Mountain Research Station General Technical Report RMRS-GTR-74, 428 pp.

BURNER, C.J., 1951, Characteristics of spawning nests of Columbia river salmon, U.S. Fish and Wildlife Service: Fishery Bulletin, 61, pp. 97-110.

BUTLER, P.J., N. DAY, 1993, The relationship between intracellular $p H$ and swimming performance of brown trout exposed to neutral and sub lethal $p H$, Journal of Experimental Biology, 176, pp. 271-284.

BUTLER, P.J., N. DAY, K. NAMBA, 1992, Interactive effects of seasonal temperature and low $p H$ on resting oxygen uptake and swimming performance of 
adult brown trout (Salmo trutta), Journal of Experimental Biology, 165, pp. 195212.

CHAMPOUX, O., P.M. BIRON, A.G. ROY, 2003, The long-term effectiveness of fish habitat restoration practices: Lawrence Creek, Wisconsin, Annals of the Association of American Geographers, 93(1), pp. 42-54.

CHAPMAN, D.W., 1988, Critical review of variables used to define effects of fines in redds of large salmonids, Transactions of the American Fisheries Society, 117(1), pp. 1-21.

CHURCH, M., J. WOLCOTT, J. MAIZELS, 1990, Palaeovelocity: a parsimonious proposal, Earth Surface Processes and Landforms, 15, pp. 475-480.

CLIFFORD, N.J., A. ROBERT, K.S. RICHARDS, 1992, Estimation of flow resistance in gravel-bedded rivers: A physical explanation of the multiplier of roughness length, Earth Surface Processes and Landforms, 17, pp. 111-126.

CONANT JR., B., 2001, A PCE plume discharging to a river: investigation of flux, geochemistry, and biodegradation in the stream bed, Ph.D thesis.

COOPER, A.C., 1965, The effect of transported stream sediments on the survival of sockeye and pink salmon eggs and alevin, International Pacific Salmon Committee, Bulletin 18, New Westminster, B.C..

CRISP, D.T., P.A. CARLING, 1989, Observation on siting, dimensions and structure of salmonid redds, Journal of Fish Biology, 34, pp. 119-134.

CROWDER, D.W., P. DIPLAS, 2000, Evaluating spatially explicit metrics of stream energy using hydrodynamic model simulations, Canadian Journal of Fisheries and Aquatic Sciences, 57, pp. 1497-1507.

CURRY, R.A., D.L.G. NOAKES, 1995, Groundwater and the selection of spawning sites by brook trout (Salvelinus fontinalis), Canadian Journal of Fisheries and Aquatic Sciences, 52, pp. 1733-1740.

DAVIS, J.A., L.A. BARMUTA, 1989, An ecologically useful classification of mean and near-bed flows in streams and rivers, Freshwater biology, 21, pp. 271-282.

DAVISON, W., G. GOLDSPINK, 1977, The effect of prolonged exercise on the lateral musculature of the brown trout (salmo trutta), Journal of Experimental Biology, 70, pp. 1-12.

DAY, N., P.J. BUTLER, 1996, Environmental acidity and white muscle recruitment during swimming in the brown trout (salmo trutta), Journal of Experimental 
Biology, 199, pp. 1947-1959.

DEVRIES, P., 1997, Riverine salmonid egg burial depths: a review of published data and implications for scour studies, Canadian Journal of Fisheries and Aquatic Sciences, 54, pp. 1685-1698.

EINSTEIN, H.A., 1950, The bed-load function for sediment transport in open channel flows, U.S. Department of Agriculture, Soil Conservation Service, Technical Bulletin No. 1026., 80 pp.

ELLIOTT, A.H., N.H. BROOKS, 1997a, Transfer of nonsorbing solutes to a streambed with bed forms: Theory, Water Resources Research, 33, pp. 123-136.

ELLIOTT, A.H., N.H. BROOKS, 1997b, Transfer of nonsorbing solutes to a streambed with bed forms: Laboratory experiments, Water Resources Research, 33, pp. 137-151.

EMERY, J.C., A.M. GURNELL, N.J. CLIFFORD, G.E. PETTS, I.P. MORRISSEY, P.J. SOAR, 2003, Classifying the hydraulic performance of riffle-pool bedforms for habitat assessment and river rehabilitation design, River Research and Applications, 19, pp. 533-549.

EMMETT, W.W., M.G. WOLMAN, 2001, Effective discharge and gravelbed rivers, Earth Surface Processes and Landforms, 26, pp. 1369-1380.

ESPEGREN, 1996, Development of instream flow recommendations in Colorado using R2CROSS, Colorado Water Conservation Board, Department of Natural Resources, Water Rights Investigation Section, Denver Colorado.

ESSINGTON, T.E., P.W SORENSEN, D.G. PARON, 1998, High rate of redd superimposition by brook trout (Salvelinus fontinalis) and brown trout (Salmo trutta) in a Minnesota stream cannot be explained by habitat availability alone, Canadian Journal of Fisheries and Aquatic Sciences, 55, pp. 2310-2316.

EVEREST, F.H., D.W. CHAPMAN, 1972, Habitat selection and spatial interaction by juvenile chinook salmon and steelhead trout in two Idaho streams, Journal of Fisheries Research Board of Canada, 29(1), pp. 91-100.

FOLK, R.L., W.C. WARD, 1957, Brazos river bar: study in the significance of grain size parameters, Journal of Sedimentary Petrology, 27, pp. 3-26.

FRIEDMAN, G.M., J.E SANDERS, 1978, Principles of sedimentology, New York, John Wiley \& Sons.

GILLER, P.S., B. MALMQVIST, 1998, The Biology of Streams and Rivers, 
3rd ed. New York; Toronto: Oxford.

GIPPEL, C.J., M.J. STEWARDSON, 1998, Use of wetted perimeter in defining minimum environmental flows, Regulated Rivers: Research \& Management, 14, pp. 53-67.

GRAY, J., 1932, The osmotic properties of the eggs of the trout (Salmo fario), Journal of Experimental Biology, 9, pp. 277-299.

GROST, R.T., W.A. HUBERT, T.A. WESCHE, 1990, Redd site selection by brown trout in Douglas creek, Wyoming, Journal of Freshwater Ecology, 5(3), pp. 365-371.

GROST, R.T., W.A. HUBERT, T.A. WESCHE, 1991, Description of brown trout in a mountain stream, Transactions of the American Fisheries Society, 120, pp. $582-588$.

HANSEN, E.A., 1975, Some effects of groundwater on brown trout redds, Transactions of the American Fisheries Society, 1, pp. 100-110.

HARTLEY, A.M., 1999, The pool-riffle sequence as the principal design component of low-gradient, meandering, gravel-bed channels, M.Sc thesis.

HAYES, J.W., 1987, Competition for spawning space between brown (Salmo trutta) and rainbow trout (S. gairdneri) in a lake inlet tributary, New Zealand, Canadian Journal of Fisheries and Aquatic Sciences, 44, pp. 40-47.

HEGGBERGET, T.G., 1991, Some environmental requirements of Atlantic salmon, American Fisheries Society Symposium, 10, pp. 132-135.

HEY, R.D., 1979, Flow resistance in gravel-bed rivers, Journal of the Hydraulics Division, American Society of Civil Engineers, 105, pp. 365-379.

HOAR, W.S., D.J. RANDALL, 1978, Fish Physiology, vol. vii: Locomotion, New York: Academic Press.

HOBBS, D.F., 1937, Natural reproduction of quinnat salmon, brown and rainbow trout in certain New Zealand waters, New Zealand Marine Department Fisheries Bulletin 6, 104 pp.

IMHOF J.G., J. FITZGIBBON, W.K. ANNABLE, 1996, A hierarchical evaluation system for characterizing watershed ecosystems for fish habitat, Canadian Journal of Fisheries and Aquatic Sciences, 53, pp. 312-326.

INMAN, D.L., 1952, Measures for describing the size distribution of sediments, 
Journal of Sedimentary Petrology, 22, pp. 125-145.

INTERAGENCY ADVISORY COMMITEE ON WATER DATA, 1982, Guidelines for determining flood flow frequency, Bulletin \#17B of the Hydrology Subcommittee, Office of Water Data Coordination. USGS, Reston, VA, 194 pp.

JOBSON, H.E., W.P. CAREY, 1989, Interaction of fine sediment with alluvial streambeds, Water Resources Research, 25, pp. 135-140.

JONES, D.R., 1971, The effect of hypoxia and anaemia on the swimming performance of rainbow trout (salmo gairdneri), Journal of Experimental Biology, 55, pp. 541-551.

JONES, J.W., J.N. BALL, 1954, The spawning behaviour of brown trout and salmon, British Journal of Animal Behaviour, 2, pp. 103-114.

JOWETT, I.G., 1993, A method for objectively identifying pool, run, and riffle habitats from physical measures, New Zealand Journal of Marine and Freshwater Research, 27, pp. 241-248.

JULIEN, P.Y., 1998, Erosion and Sedimentation, Cambridge University Press.

JULIEN, P.Y., 2002, River Mechanics, Cambridge University Press.

KELLER, E.A., 1971, Areal sorting of bed-load material: The hypothesis of velocity reversal, Geological Society of America Bulletin, 82, pp. 735-756.

KEULEGAN, G.H., 1938, Laws of turbulent flow in open channels, Journal of Research of the National Bureau of Standards, Research Paper RP1151, 21, pp. 707-741.

KNIGHTON, D., 1998, Fluvial Forms and Processes: A New Perspective, Oxford University Press Inc., New York.

KONDOLF, G.M., 2000, Assessing salmonid spawning gravel quality, Transactions of the American Fisheries Society, 129, pp. 262-281.

KONDOLF, G.M., M.G. WOLMAN, 1993, The size of salmonid spawning gravels, Water Resources Research, 29(7), pp. 2275-2285.

KONDOLF, G.M., M.J. SALE, M.G. WOLMAN, 1993, Modification of fluvial gravel size by spawning salmonids, Water Resources Research, 29(7), pp. 22652274 .

LACEY R.W.J., R.G. MILLLAR, 2004, Reach scale hydraulic assessment 
of instream salmonid habitat restoration, Journal of the American Water Resources Association, 40(6), pp. 1631-1644.

LAMOUROUX, N., H. CAPRA, 2002, Simple predictions of instream habitat model outputs for target fish populations, Freshwater biology, 47, pp. 1543-1556.

LAMOUROUX, N., H. CAPRA, M. POUILLY, 1998, Predicting habitat suitability for lotic fish: linking statistical hydraulic models with multivariate habitat use models, Regulated Rivers: Research \& Management, 14, pp. 1-11.

LAMOUROUX, N., H. CAPRA, M. POUILLY, Y. SOUCHON, 1999, Fish habitat preferences in large stream of southern France, Freshwater biology, 42, pp. 673-687.

LAMOUROUX, N., Y. SOUCHON, 2002, Simple predictions of instream habitat model outputs for fish habitat guilds in large streams, Freshwater biology, 47, pp. 1531-1542.

LANE, E.W., 1955, The importance of fluvial morphology in hydraulic engineering, Proceedings of the American Society of Civil Engineers, 81, pp. 1-17.

LEOPOLD, L.B., M.G. WOLMAN, J.P. MILLER, 1964, Fluvial Processes in Geomorphology, Courier Dover Publications.

LEOPOLD, L.B., T. MADDOCK JR, 1953, The hydraulic geometry of stream channels and some physiographic implications, U.S.G.S Professional Paper 252, 57 pp.

LISLE, T.E., 1979, A sorting mechanism for a riffle-pool sequence, Geological Society of America Bulletin, 90, pp. 1142-1157.

LISLE, T.E., 1989, Sediment transport and resulting deposition in spawning gravels, north coastal California, Water Resources Research, 25(6), pp. 1303-1319.

LISLE, T.E., J. LEWIS, 1992, Effects of sediment transport on survival of salmonid embryos in a natural stream: A simulation approach, Canadian Journal of Fisheries and Aquatic Sciences, 49, pp. 2237-2344.

LOTSPEICH, F.B., F.H. EVEREST, 1981, A new approach for reporting and interpreting textural composition of spawning gravel, U.S.D.A. Forestry Service Research note PNW-369, 11 pp.

MADDOCK, I., 1999, The importance of physical habitat assessment for evaluating river health, Freshwater biology, 41, pp. 373-391. 
MONIN, A.S., A.M. YAGLOM, 1971, Statistical Fluid Mechanics: Mechanics of Turbulence Vol.1, MIT Press.

MOODY, J.A., J.D. SMITH, 2004, Field measurements of Reynolds stress near a riverbank, Hydraulic Measurements and Experimental Methods Conference 2002, 1-12 pp.

MORISAWA, M., 1968, Streams: their Dynamics and Morphology, New York: McGraw-Hill.

NAIMAN, R.J., S.E. BUNN, C. NILSSON, G.E. PETTS, G. PINAY, L.C. THOMPSON, 2002, Legitimizing fluvial ecosystems as users of water: An overview, Environmental Management, 30(4), pp. 455-467.

NEWBURY, R.W., M. GADBOURY, 1993, Stream Analysis and Fish Habitat Design: A Field Manual, Gibsons, B.C.: Newbury Hydraulics.

NIKURADSE, J., 1933, Laws of flow in rough pipes, National Advisory Committee for Aeronautics, Technical Memorandum 1292. Translated from German in 1950, $62 \mathrm{pp}$.

ORCUTT, D.R., B.R. PULLIAM, A. ARP, 1968, Characteristics of steelhead trout redds in Idaho streams, Transactions of the American Fisheries Society, 97(1), pp. 42-45.

ORTLEPP, J., U. MÜRLE, 2003, Effects of experimental flooding on brown trout (Salmo trutta fario L.): The river Spöl, Swiss National park, Aquatic Sciences, 65, pp. 232-238.

OTTAWAY, E.M., P.A. CARLING, A. CLARK, N.A. READER, 1981, Observations on the structure of brown trout, Salmo trutta Linnaeus, redds, Journal of Fish Biology, 19, pp. 593-607.

PACKMAN, A.I., N.H. BROOKS, J.J. MORGAN, 1997, Experimental techniques for laboratory investigation of clay colloid transport and filtration in a stream with a sand seal, Water, Air and Soil Pollution, 99, pp. 113-122.

PHILlIPS, R.W., R.L. LANTZ, E.W. CLAIRE, J.R. MORING, 1975, Some effects of gravel mixtures on emergence of coho salmon and steelhead trout fry, Transactions of the American Fisheries Society, 3, pp. 461-466.

POFF, N.L., J.D. ALLAN, M.B. BAIN, J.R. KARR, K.L. PRESTEGAARD, B.D. RICHTER, R.E. SPARKS, J.C. STROMBERG, 1997, The Natural Flow Regime, BioScience, 47(11), pp. 769-784. 
PRANDTL, L., 1932, Zur turbulenten stroemung im rohren und leange platten, Ergeb. Aerodyn. Versuch., series 4. Göettingen.

RALEIGH, R.F., L.D. ZUCKERMAN, P.C. NELSON, 1986, Habitat suitability index models and instream flow suitability curves: brown trout, U.S. Department of the Interior. Fish and Wildlife Service: Biological report 82(10.24), 77 pp.

RALEIGH, R.F., T. HICKMAN, R.C. SOLOMON, 1984, Habitat suitability information: rainbow trout, U.S. Department of the Interior. Fish and Wildlife Service: FWS/OBS-82/10.60, 74 pp.

REISER, D.W., 1976, Determination of physical and hydraulic preferences of brown and brook trout in the selection of spawning locations, M.Sc thesis.

REMPEL, L.L., J.S. RICHARDSON, M.C. HEALEY, 2000, Macroinvertebrate community structure along gradients of hydraulic and sedimentary conditions in a gravel-bed river, Freshwater biology, 45, pp. 57-73.

ROSGEN, D.L., 2006, Watershed assessment of river stability and sediment supply, Wildland Hydrology. Colorado.

SAMS, R.E., L.S. PEARSON, 1963, A study to develop methods for determining spawning flows for anadromous salmonids, Oregon Fish Commission (unpublished), $56 \mathrm{pp}$.

SAWYER C.N., P.L. MCCARTY, G.F. PARKIN, 1994, Chemistry for environmental engineering, McGraw-Hill. 4th ed..

SCHMETTERLING, D.A., 2000, Redd characteristics of fluvial westslope cutthroat trout in four tributaries to the Black river, Montana, North American Journal of Fisheries Management, 20, pp. 776-783.

SCHWARTZ, J.S., E.E. HERRICKS, 2007, Evaluation of pool-riffle naturalization structures on habitat complexity and the fish community in an urban Illinois stream, River Research and Applications, 23, pp. 451-466.

SCOTT, W.B., E.J. CROSSMAN, 1998, Freshwater Fishes of Canada, Galt House Publications Ltd..

SHIELDS, 1936, Anwendung der Aehnlichkeitsmechanik und der Turbulenzforschung auf die Geschiebebewegung. [English title: Application of similarity principles and turbulence research to bed-load movement. translated by W.P. Ott and J.C. van Uchelen./, Mitteilungen der preussischen Nersuchsnastalt fur Wassed Brau end Schiffbuar (REP. No. 167). Pasedena, CA: California Institute of Technology., 46 pp. 
SHIRVELL, C.S., R.G. DUNGEY, 1983, Microhabitats chosen by brown trout for feeding and spawning in rivers, Transactions of the American Fisheries Society, 112, pp. 355-367.

SMITH, A.K., 1973, Development and application of spawning velocity and depth criteria for Oregon salmonids, Transactions of the American Fisheries Society, 2, pp. 312-316.

SMITH, D.L., E.L. BRANNON, 2007, Influence of cover on mean column hydraulic characteristics in small pool riffle morphology streams, River Research and Applications, 23, pp. 125-139.

SORENSEN, P.W., J.R. CARDWELL, T. ESSINGTON, D.E. WEIGEL, 1995, Reproductive interactions between sympatric brook and brown trout in a small Minnesota stream, Canadian Journal of Fisheries and Aquatic Sciences, 52, pp. 1958-1965.

SOUCHON, Y., H. CAPRA, 2004, Aquatic habitat modelling: biological validations of IFIM/PHABSIM methodology and new perspectives, Hydroécologie Appliquée, 14(1), pp. 9-25.

SOWDEN, T.K., G. POWER, 1985, Prediction of rainbow trout embryo survival in relation to groundwater seepage and particle size of spawning substrates, Transactions of the American Fisheries Society, 114, pp. 804-812.

STALNAKER, C., B.L. LAMB, J. HENRIKSEN, K. BOVEE, J. BARTHOLOW, 1995, The incremental flow incremental methodology: A primer for IFIM, U.S. Department of the Interior. Biological report 29, 46 pp.

STATZNER, B., J.A. GORE, V.H. RESH, 1988, Hydraulic stream ecology: observed patterns and potential applications, Journal of the North American Benthological Society, 7(4), pp. 307-360.

STONE, M.C., R.H. HOTCHKISS, R.R. MORRISON, 2006, Turbulence observations in cobble-bed rivers, World Environmental and Water Resource Congress 2006: Examining the Confluence of Environmental and Water Concerns, , pp. 9.

STRICKLER, A., 1923, Beitrage zur Frage der Geschwindigheitsformel und der Rauhigkeitszahlen fur Strome, Kanale und Geschlossene Leitungen, Mitteilungen des Eidgenossischer Amtes fur Wasserwirtschaft. Bern, Switzerland, 16 pp.

STUART, T.A., 1953, Spawning migration, reproduction, and young stages of loch trout (Salmo trutta L.), Scottish Home Department, Freshwater and Salmon Fisheries Research 5, Edinburgh., 39 pp. 
STUART, T.A., 1953, Water currents through permeable gravels and their significance to spawning salmons, etc., Nature, 172, pp. 407-408.

STURM, T.W., 2001, Open channel hydraulics, New York: McGraw-Hill.

TAPPEL, P.D., T.C. BJORNN, 1983, A new method of relating size of spawning gravel to salmonid embryo survival, North American Journal of Fisheries Management, 3, pp. 123-135.

TENNANT, D.L., 1976, Instream flow regimens for fish, wildlife, recreation and related environmental resources, Fisheries, 1(4), pp. 6-10.

THIBODEAUX, L.J., J.D. BOYLE, 1987, Bedform-generated convective transport in bottom sediment, Nature, 325, pp. 341-343.

TRUSH W.J., 1989, Salmonid geomorphology, Proceedings of the Wild Trout IV Symposium, Yellowstone National Park, Wyoming, September 18-19, 163-169 pp.

U.S. DEPARTMENT OF THE INTERIOR U.S. GEOLOGICAL SURVEY, 2001, PHA BSIM for Windows: UserŠs Manual and Exercises, Midcontinent Ecological Science Center November 2001 Open File Report 01-340, 299 pp.

VANONI, V.A., 2006, Sedimentation Engineering, 2nd ed. Reston, Va.: American Society of Civil Engineers.

VAUX, W.G., 1968, Intergravel flow and interchange of water in a streambed, U.S. Fish and Wildlife Service: Fishery Bulletin, 66, pp. 479-489.

VOGEL, S., 1994, Life in Moving Fluids: The Physical Biology of Flow, Princeton University Press.

VON KÁRMÁN, T., 1930, Mechanische Ähnlichkeit und Turbulenz, Weidmannsche Buchh, 60 pp.

WÖRMAN, A., A.I. PACKMAN, H. JOHANSSON, K. JONSSON, 2002, Effects of flow induced exchange in hyporheic zones on longitudinal transport of solutes in streams and rivers, Water Resources Research, 38(1), pp. 2.1-2.15.

WADDLE, T.J., 2001, PHABSIM for Windows: user's manual and exercises, U.S. Geological Survey Open-File Report 01-340, 288 pp.

WADESON, R.A., K.M. ROWNTREE, 1998, Application of the hydraulic biotope concept to the classification of instream habitats, Aquatic Ecosystems Health 
and Management, 1, pp. 143-157.

WHEATON, J.M., G.B. PASTERNACK, J.E. MERZ, 2004, Spawning habitat rehabilitation - I. Conceptual approach and methods, International Journal of River Basin Management, 2(1), pp. 3-20.

WHITE, C.M., 1940, The equilibrium of grains on the bed of a stream, Proceedings of the Royal Society of London. Series A, Mathematical and Physical Sciences, 174(958), pp. 322-338.

WICKETT, W.P., 1954, The oxygen supply to salmon eggs in spawning beds, Journal of the Fisheries Research Board of Canada, 11(6), pp. 933-953.

WITZEL, L.D., H.R. MACCRIMMON, 1983a, Redd-site selection by brook trout and brown trout in southwestern Ontario streams, Transactions of the American Fisheries Society, 112, pp. 760-771.

WITZEL, L.D., H.R. MACCRIMMON, 1983b, Embryo survival and alevin emergence of brook charr, Salvelinus fontinalis, and brown trout, Salmo trutta, relative to redd gravel composition, Canadian Journal of Zoology, 61, pp. 1783-1792.

WOLMAN, M.G., 1954, A method of sampling coarse river-bed material, Transactions of the American Geophysical Union, 35(6), pp. 951-956.

WU, F-C, 2000, Modeling embryo survival affected by sediment deposition into salmonid spawning gravels: Application to flushing flow prescriptions, Water Resources Research, 36(6), pp. 1595-1603.

YALIN, M.S., E. KARAHAN, 1979, Inception of Sediment Transport, Journal of the Hydraulics Division, ASCE, 105, pp. 1433-1443.

YANG, C.T., 1996, Sediment transport: Theory and Practice., New York: McGrawHill.

YANG, C.T., C.C.S SONG, 1979, Theory of minimum rate of energy dissipation, Journal of the Hydraulics Division, American Society of Civil Engineers, 105, pp. 769-784.

YANG, T.Y., 1971, Formation of riffles and pools, Water Resources Research, 7(6), pp. 1567-1574.

YANG, T.Y., 1972, Unit stream power and sediment transport, Journal of the Hydraulics Division, Proceedings of the A.S.C.E., 1805-1826 pp.

ZIMMER, M.P., M. POWER, 2006, Brown trout habitat selection preferences 
and redd characteristics in the Credit river, Ontario, Journal of Fish Biology, 68, pp. 1-14.

ZIMMERMANN, A.E., M. LAPOINTE, 2005, Intergranular flow velocity through salmonid redds: Sensitivity to fines infiltration from low intensity sediment transport events, River Research and Applications, 21, pp. 865-881.

ZOTIN, A.I., 1958, The mechanism of hardening of the salmonid egg membrane after fertilization or spontaneous activation, Journal of Embryology \& Experimental Morphology, 6(4), pp. 546-568. 